Historic, Archive Document

Do not assume content reflects current scientific knowledge, policies, or practices. 
F. S. -81

UNITED STATES DEPARTMENT OF AGRICULTURE

Office of Foreign Agricultural Relations

TOBACCO PRODUCTION AND CONSUMPTION IN THE NETHERLANDS INDIES

By J. Barnard Gibbs

Tobacco Specialist

Washington, D. C.

March 1940 


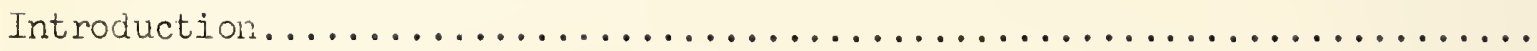

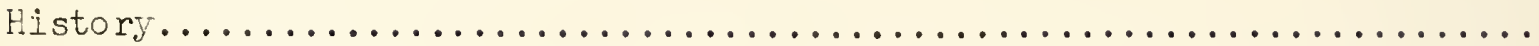

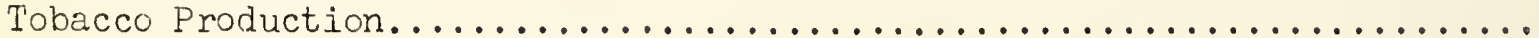

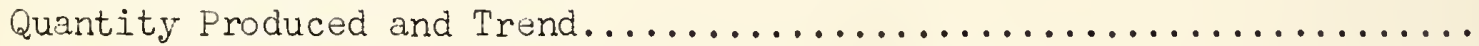

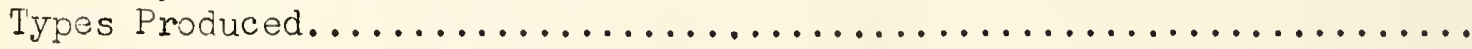

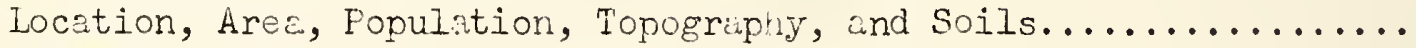

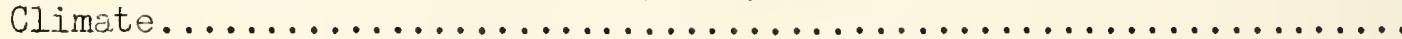

Tobacco Districts, Their Soil, Climate, Tobacco Grown, and

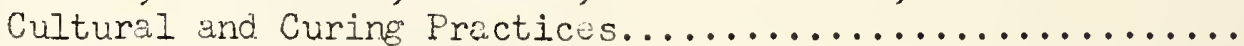

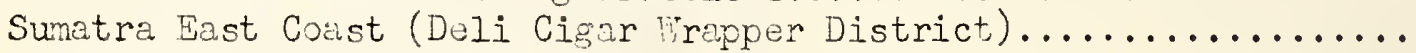

Types of Sunatra

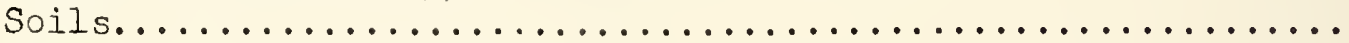

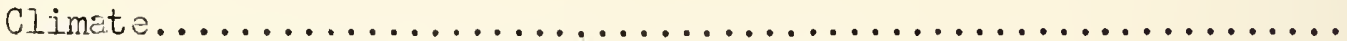

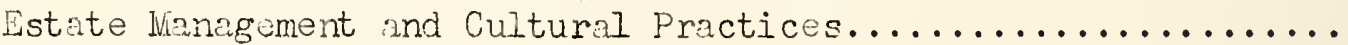

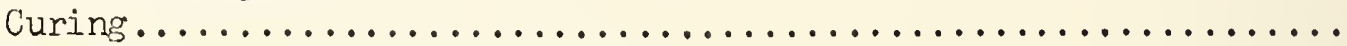

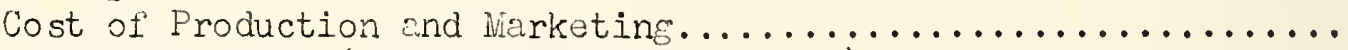

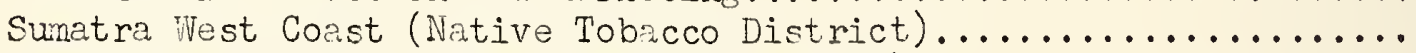
Vorstenlanden Java (Cigar Tobacco District).................

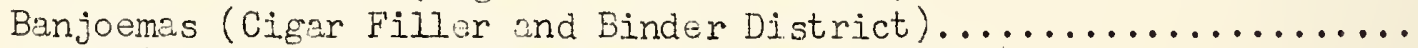
Kedoe (Cigar Filler and Native Tobacco District)................ Besoeki (Cigar Filler and Binder and Native Tobacco District)...... Rembang and Kediri (Flue-cured end Native Tobacco Districts).......

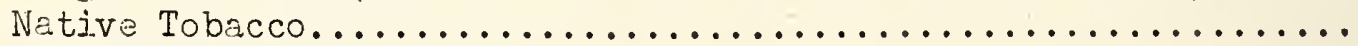

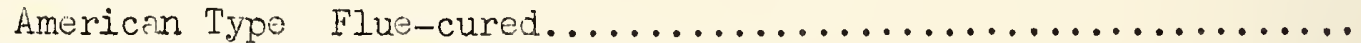

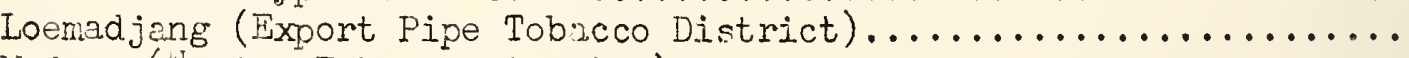

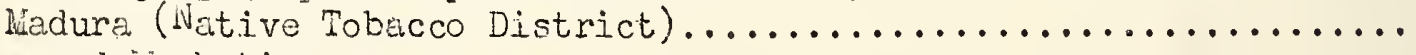

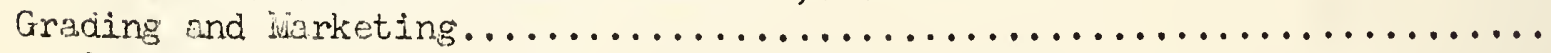

Grading. . . . . . . . . . . . . . . . . . . . . . . . . . . . . .

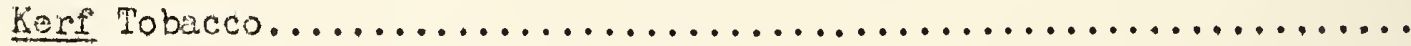

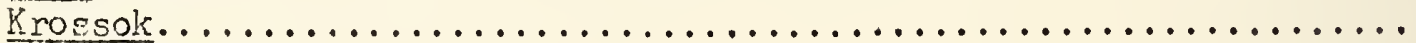

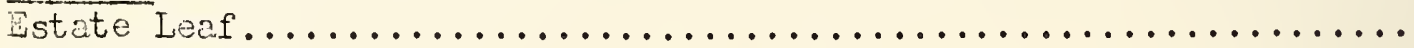

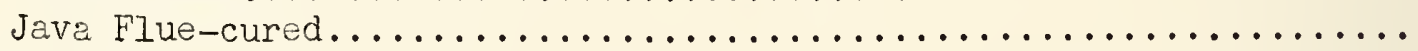

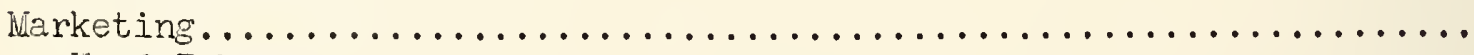

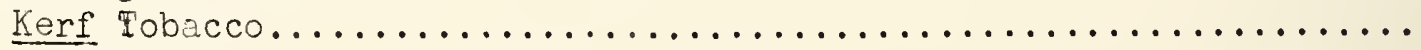

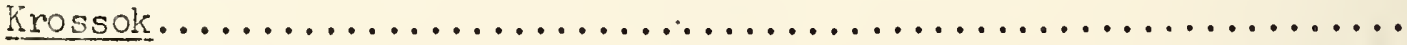

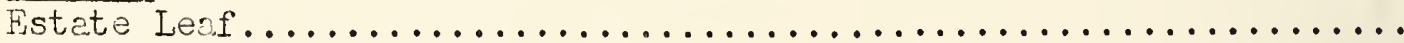

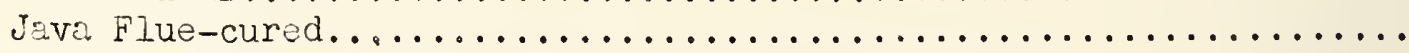

Imports and Exports of Leaf Tobecco and Tobacco Products..............

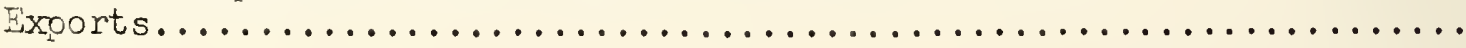

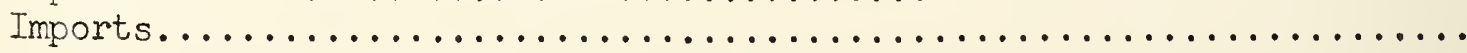

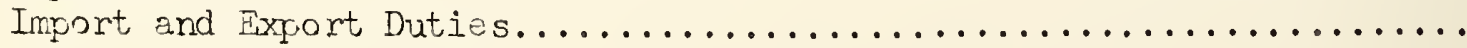




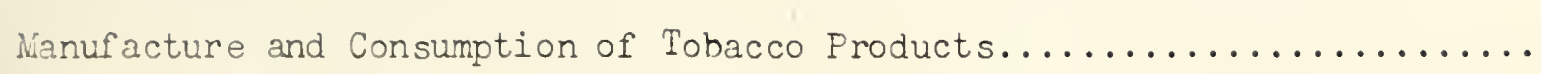

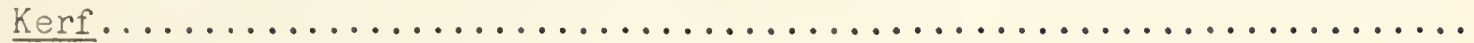

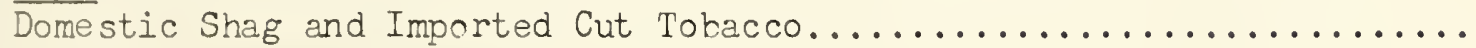

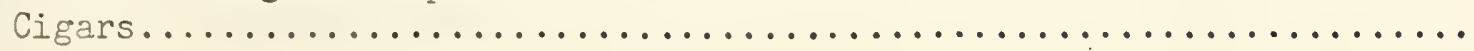

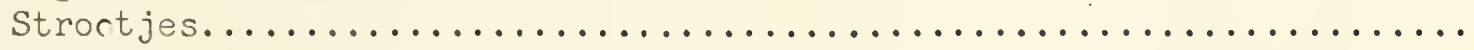

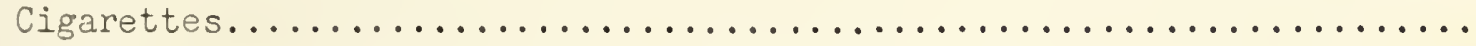

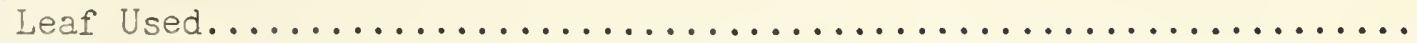

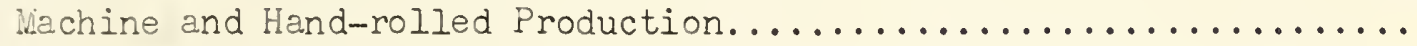
Government Supervision of Machine Cigarette vianufacturing Companies

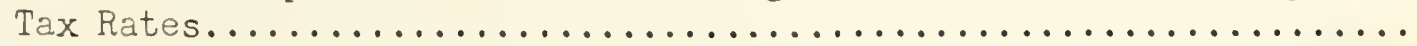

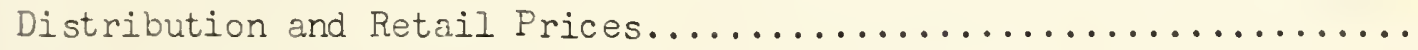
Probable Developments Affecting American Tobacco Farmers............... Table of Appendixes

I Imports of Leaf Tobacco and Tobacco Products by Sources.......... II Exports of Leaf Tobacco and Tobacco Products by Destinations.....

III Industries, Licenses, Permits, Cigarette Factories............. Page Tabulations:

Approximate production, export, import, and quantity available for

domestic consumption of tobacco (fermented weight) in the

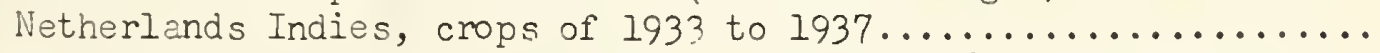

Acreage of specified kinds of tobacco in Sumatra, Java, and liadura,

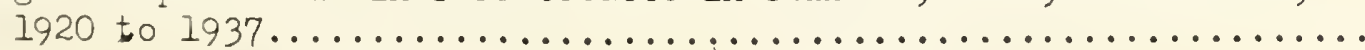

Production of specified kinds of tobacco (fermented weight) in

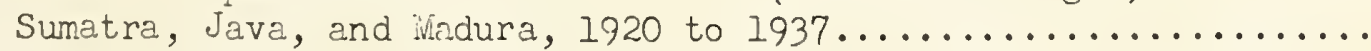

Average monthly and annual rainfall in leading tobacco-producing

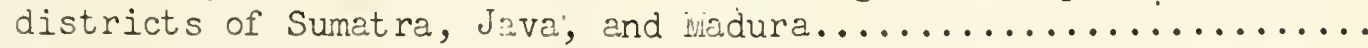

Prices received, cost of production; including delivery to the

Netherlands, and net profit of a single company in the Sumatra

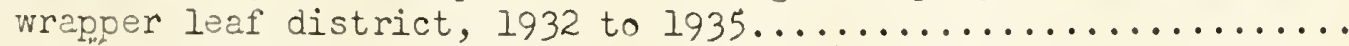

Approximate acreage, production (farm weight), and price of tobacco

from American flue-cured seed in Jàia, 1928 to $1938 \ldots . . . \ldots \ldots$

Sales and prices obtained for specified Netherlands Indies tobacco

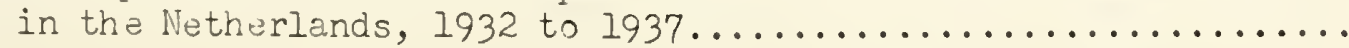

Sales in the Netherlands of Sumatra, Java, and Nadura tobacco,

quantities retained for domestic use, and quantities reexported,

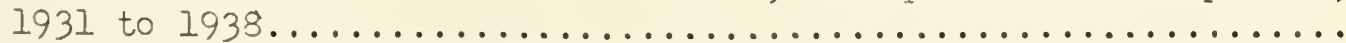

Exports of leaf, Krossok and Kerf tobacco, 1920 to $1938 \ldots . . . \ldots \ldots . . .$.

Exports and imports of leaf tobacco and tobacco products from the

Netherlands Indies and excess of combined exports over combined

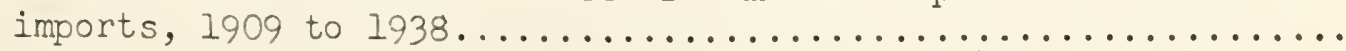

Approximete quintities of tobacco (processing order) used in the

manufacture of tobacco products in the Netherlands Indies,

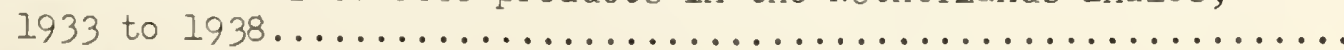

Percentage of sales of each tobacco product in terms of value, price groups, and percentage each product of all products, 1933-1938.. 


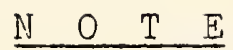

All units of weight's and measures used in this report are, unless otherwise specified in places where used, those recognized as standard in the United States. Unless otherwise stated, quotation's of prices and values are in United States dollars and cents. Conversions of prices and values that apply to particular periods have been made at rates effective during those periods.

The following tabulation shows exchange rates for 1913 and 1920 to 1939, inclusive:

\section{United States cents per}

$\frac{\text { Year }}{1913 \ldots} \frac{\text { guilder }}{40.211}$

$1920 \ldots \ldots 33.250$

$1922 \ldots \ldots 37.313$

$1923 \ldots . .37 .453$

$1924 \ldots \ldots 37.488$

$1925 \ldots \ldots 40.000$

$1926 \therefore \therefore \therefore 40.222$
United States cents per $\frac{\text { Year }}{1927 \ldots \ldots} \frac{\text { guilder }}{40.180}$ $1928 \ldots . .40 .220$ $1929 \ldots . .40 .019$ $1930 \ldots . .40 .140$ $1931 \ldots . . .39 .960$ $1932 \ldots . .40 .019$ $1933 \ldots . .49 .596$
United States cents per

Year . guilder

$\frac{1934 \ldots .65}{6.733}$

$1935 \ldots .667 .568$

$1936 \ldots . .59 .791$

$1937 \ldots \ldots 55.172$

$1938 \ldots \ldots 55.010$

$1939 \mathrm{a} / \ldots 53.446$

1913 to 1937, compiled from highest and lowest quotations during year as published in "Netherlands Indian Report 1938 - Part II." 1938 and 1939, average of daily quotations on guilders in New York as published by Board of Governors of the Federal Reserve System.

a) January to August. 


\section{TOBACCO PRODUCTION AIND CONSUMPTION IN THË NETHERIANSS INDIES}

The Netherlands Indies has for many yesr's ranked among the leading tobaccoproducing and -exporting countries of the world. The civerage cinnual production of the islands has for most recent yuars ranged between 240 and 300 million pounds, which is in excess of the reported production in countries other than the United States, British India, China, and the Union of Soviet Socislist Republics. For the past 30 years or more, annual exports from the islands have usually ranged between 100 and 200 million pounds, which makes them second in importance to the United States as a tobacco-exporting country. lyost of the export is to the Netherlonds where part of it is sold in competition with American, particularly air-cured ana cigar types. Fairly linge quantities of Sum.tra cigar-wrapper leaf are purchased at the Netherland markets by Americ n cigar makers and leaf dealers. Java cigar-filler and pipe-tobacco types are sold almost exclusively to European buyers.

The commercial production of American-type flue-cured leaf was started in the islands in 1928 and during recent years həs expanded quite rapidly. As yet the entire output is used in cigarettes for domestic consumption, but agencies interested in its expansion, p\%rticularly the Netherlands Indies Government, are encouraging production ith a viow to enabling the export of substantial quantities. Small shipments of this lanf to the Netherlands have created an interest in it as a substitute for American flue-cured. It is hoped by the Netherlands Indies authorities that its export will in time offset the decline that has occurred during recent years in the islands' export of cigar and pipe-tobacco types.

Table 1.- Approximate production, export, import, and quantity available for domestic consumption of tobacco (fermented veight) in the Netherlands Indies, crops of 1933 to 1937

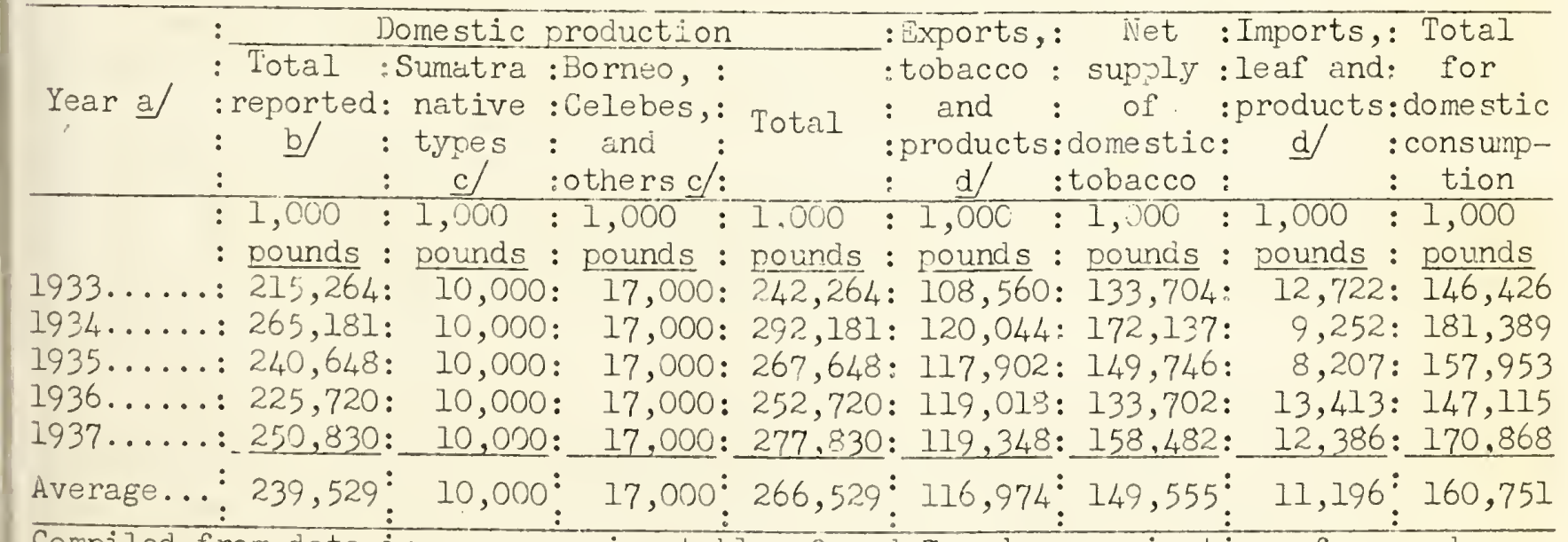

Compiled from data in accompanying tables 3 and 7 and approximations for production data not included in table 3.

a) Year of harvest; exports, net supply of domestic tobacco, imports, and total available for domestic consumption are for following year.

b/ Includes Sunatra estate tobacco and estate and native production in Java and Madura; see table 3 .

c) Approximated.

d/ Officially reported exports and imports increased 10 percent to make them approximately comparable with fermented weight. 
Tobacco consumption in the islahds during recent years has been about 160 rallion pounds, fermented weight, annually, liost of the tobacco used in products consumed is from domestic production. Substantial quantities of American fluecured have been imported either as leaf or in tobacco products; however, increases in recent years in the utilization of both domestic flue-cured and Java types suitable for domestic cigarettes have caused such imports to decline.

It is evident that Netherlands Indies tobacco competes with American leaf both abroad and in our domestic market. At the same time United States fluecured leaf is sold in the islands in competition with their domestic production. It is important, therefore, for American tobacco growers to be informed regarding all phases of the tobacco industry of the lNetherlands Indies. This report is intended to furnich such information as is available and to give some indication of probable future developments in the tobacco industry of the islands.

\section{HISTORY}

There is no record of tobacco having been grown in the Netherlands Indies prior to its introduction by Europeans. It is not found in a wild state, and the plant has always been known by its foreign name. Its cultivation was probably introduced by the Portuguese some time necir the end of the sixteenth century, and possibly later reintroduced by the Dutch. Accordine to a Javanese chronicle it was first introduced in 1601 . If

There are no authentic recoids indicating the rapidity with which production and consumption expanded during the first two centuries after its introduction; however, expansion is believed to have been slow. Even in recent years the per-capita consumption of the populetion has been relatively low and production probably did not becone significant until an export demand developed. Exports probably began during the 18th century, but it was not until the 19th century that they became large enough to indicate a significant production. In 1847, sales of Vetherlands Indies tobacco in the ivetherlands, which has been the principal export market, totiled oniy about 5,600,000 pounds.

Commerciel production of tobacco of the kinds for which the Netherlands Indies is now noted in world trade, did not begin until more recent times. The growing of Sumatra cigar-wrapper leaf had its beginnings in 1863. It was started by a single planter, J. Nienhuijs. He secured a concession for the use of land on which to grow tobacco from the Sulten of Deli, made trial plantings,

If Laufer, Berthold; "Tobacco and its use in Asia." Field wiseum of Natural History, Chicago, Illinois, 1924. The same publication also states that, "G. E. Rumpf, a botanist, who explored the flor: of the wilay Archipelago in the latter part of the seventeenth century, writes that old Javenese, according to what they had learned from their parents, told hin that the tobacco plant had been well known in Jave prior to the errival of the Portuguese, but solely for medicinal purposes, not for smoking; they st ted unenimously that they acquired the custom of smoking from Europeans. Such oral traditions, as a rule, are devoid of historical value. The same Rumpf also learned in Jave from an Amoy Chinese that the tobacco plant had from ancient times existed in China, but was rarely cultivated; and this plainly contracicts the Chin se records concerning the recent introduction." 
and in 1865 organized a plantation cumpany for extensive production. Following this start other companies were organized, and production has always been in the hends of a few large concerns with extensive holdings.

Production of Vorstenlanden Java digur tobacco began a few years prior to production in Sumatra. It his also always been in the hands of a few large plantation companies or large planters. Production of Besueki Java leaf, which his been grown largely by n.tives but much of it cured and handled by a few cumpanies, wis fairly extensive before the production of Vorstenlanden and Sumatra wrapper-leaf was started. Commarcial production in other districts, which are of less importance than those mentioned, apparently ilso began some time between 1850 and 1875. Following their introduction the trend in production of Sumatra and Java export types was upward, reaching a peak in 1914 .

Since early days a large portion of Netherlands Indies tobicco has been exported. Practically all of the astate tobiccu is grown for export, and a large part of the native crop is shipped abroad. For the years preceding and immediately following the World War, over half of total production was shipped abroad. During recent years cbuut 40 percent of the production has been axported.

Domestic consumption of tübacco has been largaly limited to nstive Kerf (cut tobacco) used in hand-mede cigarittos, "strootjes," I/ cigars, and for chewing. The consumption of cigars and machine-made cigarettes has, until recent years, been insignificcint. Even in 1938 they accounted for only about 17 percent of total poundage of tobaccu cunsumed.

\section{TUPACCO PRODUCTION}

\section{Quntity Produced and Trend}

Total production of tobacc in the Netherlands Indies during the 5 years 1933 to 1937 is estimated to hcve everaged about 267 million pounds annualiy. Official records are limited to the acreage and production on large estates, and the acreage of nonestate or native tobacco in Java and Madura.. These estimates, with an approximate average jield per acre for Java and Niadura native tobacco indicate that their totel production since $1920 \mathrm{~h}$ s ranged between 172 million and 311 million pounds annually. The trend was upward frum 1920 to 1928 but production has declined since 1928. During the 5 years 1933 to 1937 production in these districts, frm an average acrenge of 454,000 acres, nas only absut 240 milliun pounds annurlly.

Acreage and production, not officially reported, include native tubacco in all of the islands other then Java and Viadura. Production of native tobacco in sumetra in recent years is approximated by Netherlands Indies officials at 10 million pounds, and that in ther areas for which official figures are not available, at about 17 million pounds.

IJ Strootjes are made frum kerf rolled in corn shucks or tree leaves (see page 47). 


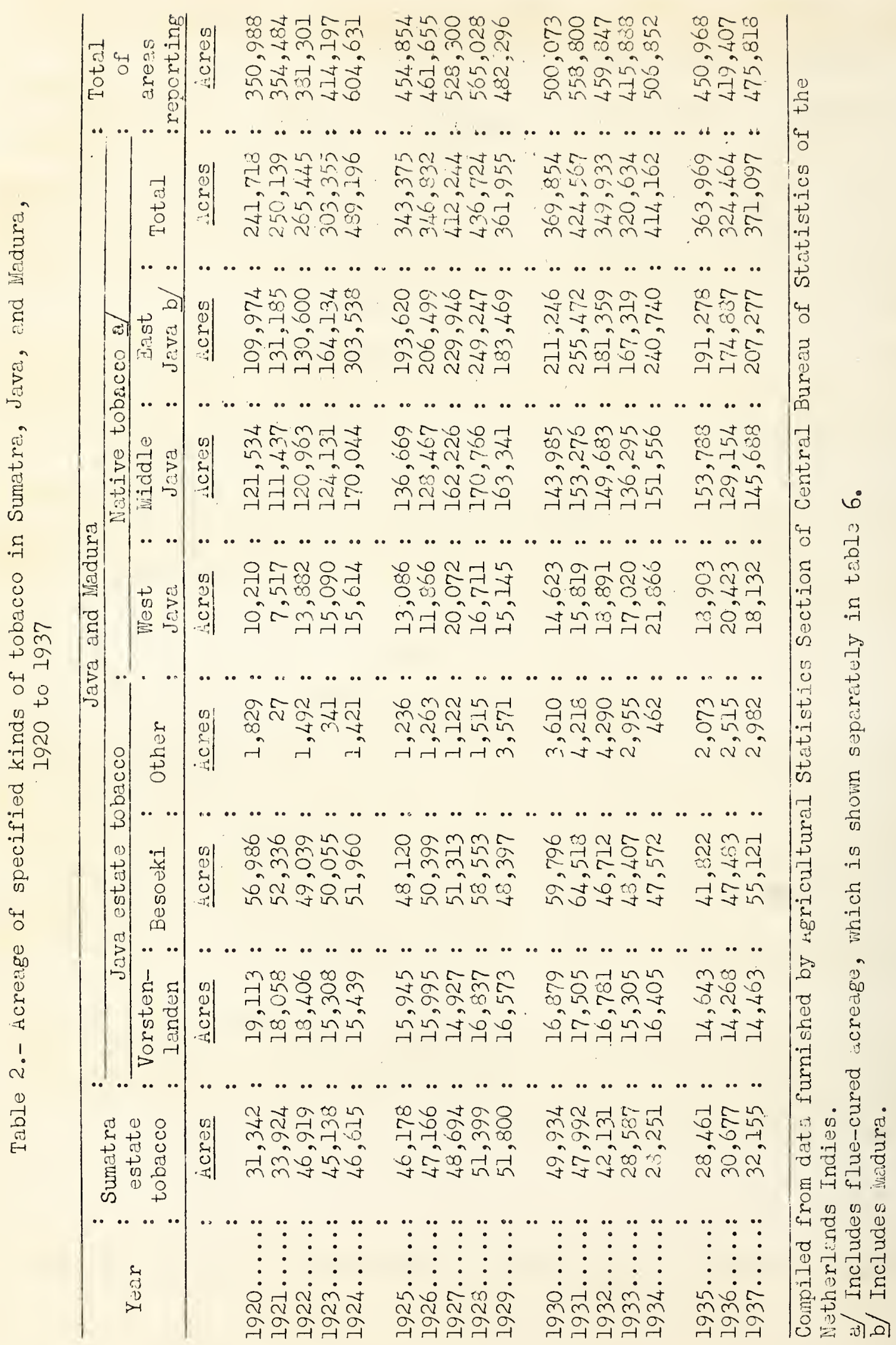




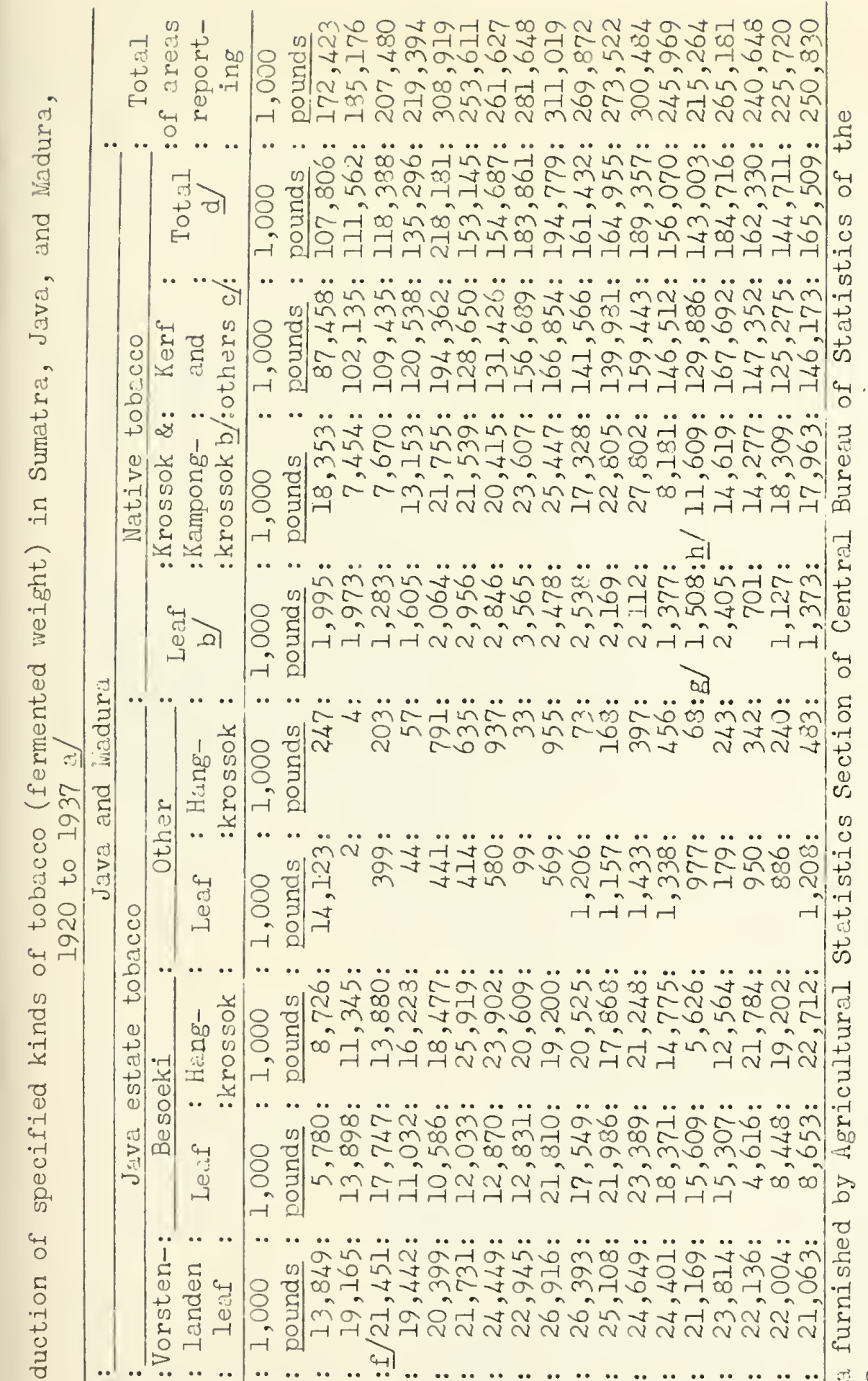

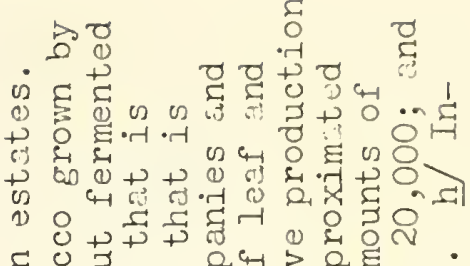

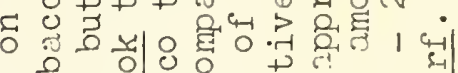

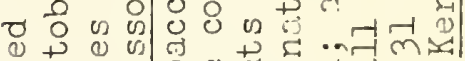

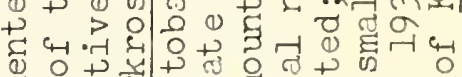

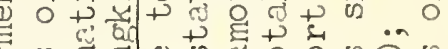

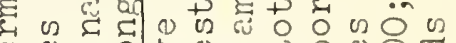
0 o $000+0,000$

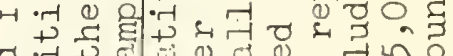

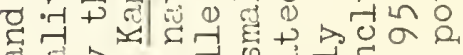

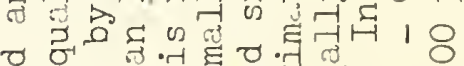
ช ज. ริ

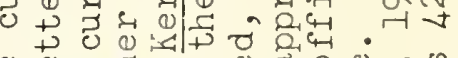

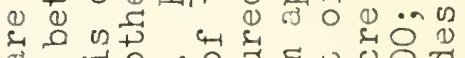
ชै

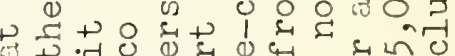

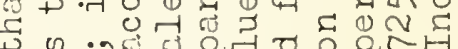

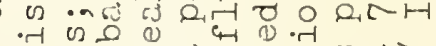

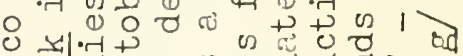
0 ० जी

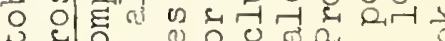

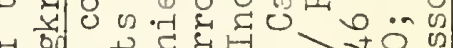

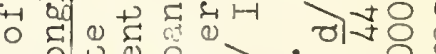

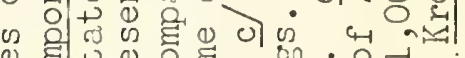

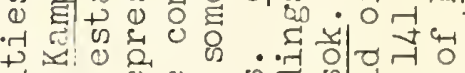
त्र न

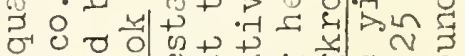

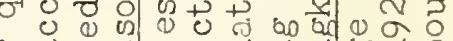

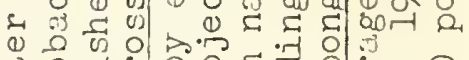
के ०.

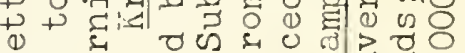
$\triangle$ बै.

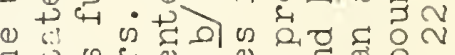

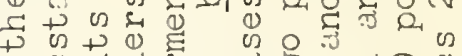

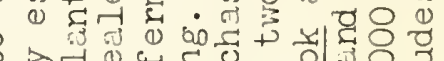
†

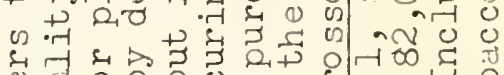

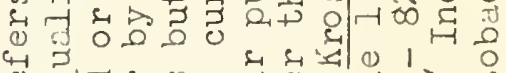
४

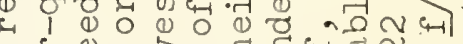

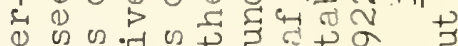
(1)

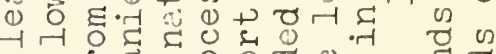
-

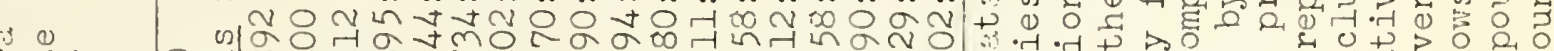

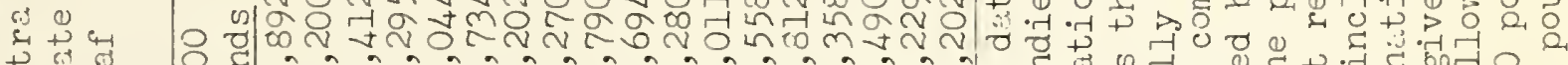

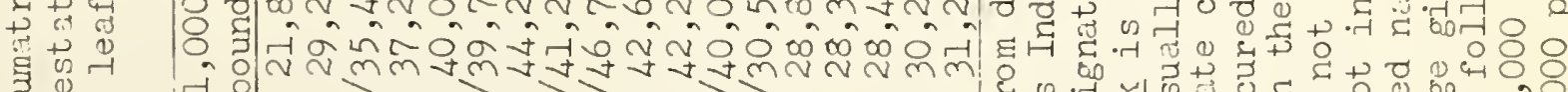
䛼这

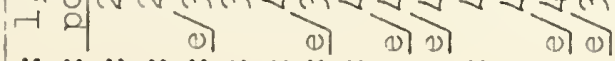




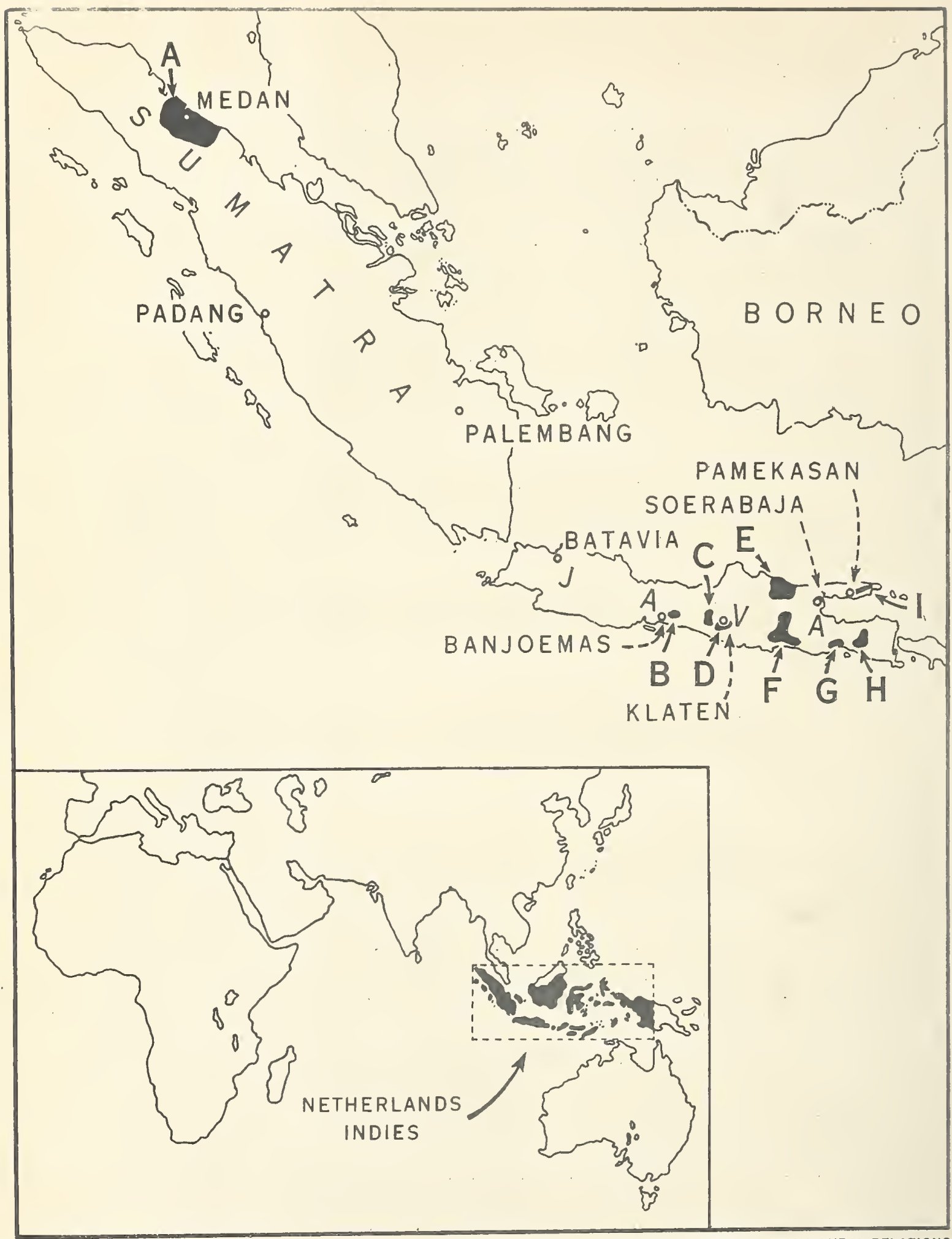




\section{Trees Froduced}

wost wetherlands Indies tobacco is of dark or relatively dark types. Under American standards they would be classed either as ciger-leaf or between the light and dark air-cured types. The tendency to some homogeneity in types can be largely attributed to the climate and soil, which are to a considerable extent determined by the location of the islands.

Location, Area, Population, Topograrhy, and Soiis

The Netherlands Inaies cumprise almost all of the Indian Archipelago. They are located along the equator between 95 degrees and 141 degrees east longitude, a distance of about 3,180 miles, or anproximately 300 miles less than the distance from New York to Sen Frincisco. The most northern land area extends to near 6 degrees north latitude, and the most southern area to 11 degrees south latitude. The distance from north to south across the islands is about 1,175 miles, or something near the distance between the northern and southern borders of the United States.

The total area of the islands is about 735,000 square miles, which is spproximitely equal the land area of the States east of the Mississippi River, excepting Georgic and Florida. It is made up of hundreds of islands varying in size from a few souare rods to about 200,000 squire'miles. The Netherland portion of Borneo, New Guinea, cind the island of Sumetra are each larger than the combined area of Illinois, Indiano, Ohio, and Pennsylvania. The islands of Java and Wadura, which are among the most densely populated areas in the world (about 820 peopla per sousre mile), have a combinad ares slightly larger then iNew York Stato.

The following tebulition shows the areas and population of difierent pirts of the Nitharlinds Indies:

\begin{tabular}{cr}
$\begin{array}{c}\text { Area } \\
\text { Square miles }\end{array}$ & $\begin{array}{r}\text { Population } \\
1930 \text { census }\end{array}$ \\
51,000 & $41,718,000$ \\
182,900 & $8,255,000$ \\
208,200 & $2,169,000$ \\
38,900 & $3,093,000$ \\
191,700 & 893,000 \\
52,600 & $4,599,000$ \\
\hline 735,300 & $60,727,000$
\end{tabular}

inost of the islands in the archipelago are very mountainous. The mountains in most cases rise abmupty from coastal plains, and there are several peaks :ith altitudes of over 10,000 feet. . any are volcanos, of which there are about 400. The coastal plain areas and valleys betveen mountain ranges are relatively large in Sumatra, Borneo, and ivtherland Guinea, but are smaller in Jeva and other islands. Soils of the islands have been derived from volcanic ash, the wathering of rock iorm.tions ind the decomposition of dense tropical vigetation. The volcanic soils are rick in minsrals, and, when they contain a 
high percentage of humus, they are very fertile. The soils derived from older rock forliations are of lower fertility. Volcanic soils are most extensive in Java. As a consequence, agriculture including tobacco growing has become more extensively developed in Juva than in the other islands.

\section{Climate}

All of the land area in the Netherlands Indies is within 760 miles of the equator, and, as a consequence, temperatures throughout the year are relatively uniform. At sea level the fluctuations in monthly average temperatures through the year in practically all parts of the archipelago only range between $77^{\circ}$ and $820 \mathrm{~F}$. The yearly average at narlyall sea-level points is about $79^{\circ} \mathrm{F}$. Cool areas are limited to muntain districts. For each 300 feet of rise in elevation there is a decline in average yesrly temperature of approximately $1^{\circ} \mathrm{F}$. Frost areas are limited to the higher mountain districts, but for most of such districts where agriculture is important frost only occurs occasionally during the coolost dry months. Daily fluctuat.ons in temperature are small throughout the year. iverage monthly maximum temperatures at sea level points throughout the islands range between $84^{\circ}$ and $900 \mathrm{~F}$. and average rinimums between $72^{\circ}$ and $77^{\circ} \mathrm{F}$.

Sunshine is plentiful. The difference between the longest and shortest daysin the year is only about 48 ininutes. Rains are frequent, but there is seldom a dey in which the sun does not shine. In some districts of heaviest rainfall the sunshine for sone months is less than 30 percent of maximum (maximum being the number of hours during the month between times of sunrise and sunset). In most districts, however, the percentage of sunshine is much higher and the yearly average for the archipelago as a whole is about 65 percent.

The atmosphere is relctively humid. ivonthly averages of relative humidity over most of the territory vary from around 75 percent in dry months to noar 90 percent in wet months. The yearly average relative humidity for the entire area is about 81 percent, average maximum about 94 , and average minimum about 59 percent.

Yearly total and seasonal rainfall vary widely, but in most areas rainfall is n too heavy or too light for crops. The avirage annual varies from 21.5 inches at Paloe, an inland town near the west cost of the Celebes, to 266.4 inches at I'ombo, an inland town of Central Java. In general, the period of greatest rainfall is from Novimber through January and the period of liast rainfall from Nay through fugust; however, in certain districts on the west coast of Sumatra, the south coast of Java, and parts of the Celebes, rainfall is low in December and Januery, as well as during the summer months, and highest in April and Uctober. There cre also some districts and islands for which the monthly average rainfall is fairly uniform throughout the year.

Districts of uniform seasonal and total annual rainfall are small. In maping such districts, the Netherlands Indies' Meteorological Bureau established 68 districts in Java and Viedura, and 84 in the other islands. This lack of unifornity as regards rinfall results from the influence of mountains and prevailing winds. Rainfall over nost of the archipelag, and purticularly the portion south of the equator, is influenced by monsoons, which blow in opposite directions at different times of the year. The southeast monsoon from over the continent of Axstralia during the months of April through October results in a period of relatively low rainfall, whereas the west and northwest monsoons from over the 
Indian Ucen during the munths of iw venber through virch result in a pricd of havy reinfi.1]. Wind currents over the purtion of the archipelngo near the equitor and north of the equater re not so well defin:d. In generil, however, winds north of the equitor blow from northedst to suthwest during the months of Nuvaraber through warch, and irum southrest t' northeast during the period spril through Octaber. This results in rinfell being heavier during the summer months than is the c:.se in aress suuth of the equator.

In many casus the nuntrins shut jif part, and in some cases nurly ill of the rains corried by the different monscons. This results in districts to the leeward of nunteins heving o nterially different secs nal and total annual rainf:.l] than thuse immeitely to the windward.

Table 4.- s.ver.ge monthly and annual rinfell in lunding tobəcc-producing districts of Surstrc, Jave, end ivedurs.

\begin{tabular}{|c|c|c|c|c|c|c|c|c|c|c|c|c|c|}
\hline \multirow[b]{2}{*}{ District } & \multirow{2}{*}{\multicolumn{3}{|c|}{$\begin{array}{l}\text { : Numbor : } \\
: \text { of } \\
\text { :stations: }\end{array}$}} & \multicolumn{10}{|c|}{ inthly aver zes } \\
\hline & & & & Jin. & $:$ & $F=b$. & $:$ & ingr. & $:$ & Apr. & $:$ & iv $y$ & $\begin{array}{l}: \text { June } \\
\end{array}$ \\
\hline & $:$ & Nusber & $:$ & Irichss & : & Inches & : & Inches & $:$ & Inches & : & Inches & : Inches \\
\hline Sumitra - & : & & : & & : & & : & & : & & : & & $:$ \\
\hline isst Cosst.... & & 10 & : & 7.8 & : & 5.3 & : & 6.2 & : & 7.0 & : & 9.4 & 6.9 \\
\hline Test Cosst..... & & 5 & : & 12.1 & : & 8.9 & : & 11.2 & : & 12.4 & : & 9.6 & 7.0 \\
\hline JUV & : & & : & & : & & : & & : & & : & & : \\
\hline Banjomis...... & & 5 & : & 18.2 & : & 16.5 & : & 19.6 & : & 13.8 & : & 9.6 & 6.2 \\
\hline hedoe......... & & 5 & : & 20.2 & : & 17.6 & : & 19.1 & : & 14.9 & : & 10.7 & 6.5 \\
\hline Vorstenl:naen. . & & 10 & : & 12.2 & : & 13.0 & : & 11.3 & : & 7.1 & • & 4.8 & 3.6 \\
\hline Remb.nng....... & & 7 & : & 13.0 & : & 12.5 & : & 11.9 & : & 7.2 & : & 5.4 & 2.6 \\
\hline Kediri......... & & 5 & : & 13.4 & : & 13.3 & : & 12.3 & : & 8.8 & & 6.3 & 3.3 \\
\hline Loemed $j=n E$. . . . & & 5 & : & 10.1 & : & 9.9 & : & 9.6 & : & 7.0 & : & 5.6 & 4.6 \\
\hline Basueki........ & & 10 & : & 16.0 & : & 13.3 & : & 12.4 & : & 7.5 & : & 5.7 & 3.1 \\
\hline wadura - & : & & : & & : & & : & & : & & : & & : \\
\hline Jistern........ & & 5 & : & 12.1 & : & 10.6 & : & 10.1 & : & 7.2 & : & 4.6 & 3.1 \\
\hline & $:$ & & $:$ & & $:$ & & $:$ & & $:$ & & : & & $:$ \\
\hline & $\begin{array}{l}: \\
:\end{array}$ & July & : & Au尺. & : & Sept. & : & Oct. & : & Nov. & : & Dec: & $\begin{array}{l}\text { : Yearly } \\
\text { : average }\end{array}$ \\
\hline Sunatra - & $:^{-}$ & licnes & $:$ & Incres & : & Inches & : & Inches & $:$ & Inches & : & Inches & : Inches \\
\hline East Coast..... & & 6.4 & : & 9.1 & : & 10.6 & : & 13.4 & : & 11.2 & : & $\overline{10.2}$ & $: \overline{103.5}$ \\
\hline lipest Cuast..... & & 7.8 & : & 10.8 & : & 12.6 & : & 14.7 & : & 17.1 & : & 14.4 & $: 138.6$ \\
\hline$J \dot{J V}=-$ & : & & : & & : & & : & & : & & : & & $:$ \\
\hline Binjuemis..... & & $3 \cdot 4$ & : & 2.6 & : & 4.0 & : & 14.1 & : & 21.5 & & 21.6 & : 151.1 \\
\hline riedue......... & & 4.1 & : & 3.6 & : & $4 \cdot 9$ & : & 11.8 & : & 18.6 & : & 22.3 & $: 154 \cdot 3$ \\
\hline Vorsterlnnden. . & & 1.2 & : & 1.2 & : & 1.1 & : & 3.9 & : & 7.7 & : & 11.4 & $: \quad 73.5$ \\
\hline Remban $\ldots \ldots$. & & 1.6 & $:$ & 1.3 & : & 1.7 & : & 4.2 & : & 8.2 & : & 12.1 & 81.7 \\
\hline Kediri........ & & 1.6 & : & 1.1 & : & 1.4 & : & 3.8 & : & 3.2 & : & 12.3 & 85.3 \\
\hline Lounrdjung . . . . & & 3.1 & : & 3.0 & : & 2.5 & : & 6.6 & $:$ & 8.9 & : & 9.5 & 80.4 \\
\hline Besueki......... & & 1.5 & : & 1.4 & : & 1.7 & : & $4 \cdot 7$ & : & 9.3 & : & 13.7 & 90.3 \\
\hline ijécidura - & : & & $:$ & & : & & : & & : & & : & & : \\
\hline Eustern....... & & 1.6 & : & 0.4 & : & 0.5 & : & 1.7 & : & 5.6 & : & 9.7 & 67.2 \\
\hline
\end{tabular}

Corpled frun dita publishod in "keinf:.11 in the Netherlands Indies" by Prof. Dr. J. Buerema, Bitavia, Jiva.

a) averagis at selected stations scuttered throuchout the districts. 


\section{Tobacco Districts, Their Soil, Climto, Tobsceo Grown, ind Cultural and Curing Practices}

There are nine well-defined tobacco-producing districts in the Netherland Indies which grow recogrized export types of tobecco. They include the Deli district on the east coast of Sumatra, seven districts in central and east Jeva, nauly, Banjoemas, Kedoe, Vorstenlenden, Rembang, Kediri, Loemadjang, and Besoeki; and a district on the islend of Madura.

The production of native tobacco, largely kerf, is carried on throughout the islands. The most important districts are the west coast of Sumatra near the port of Padang, the southeast section of Sumatra near Palembang, central and eastern Java, Bali, Lombok, and Celebes. Production in Borneo, Netherlands Guinea, and the other islands is limited; in most cases it does not eoual local requirements.

\section{Sumatra Gast Coast (Deli Cigar Erapper District)}

The Sumatra cigar wrapper distrjet is confired to a limited area on the northeast coast of the island of Sumatra and is all within a radius of about 25 miles of the town of iledan, the capital of Sumatra. The development of the district has resulted from the special properties of its soil and climete, which make for the production of a high grade, thin, elastic leaf. The first tobacco shipped to the Netherlands from the district in 1865, a lot of 50 bales, was immediately recognized for its excellent quality. It as sold originally for 0.48 guilder per half-kilo (24 cents per pound at the 1939 exchange), but was reported to have changed hands severel times at increased prices. In the following year a shipment of 189 baies sold for an original price of 1.49 guilders per half-kilo ( $75^{\circ}$ cents per pound at the 1939 exchange). Fith this beginning, production expanded rapidly and for many years there has been a continuous demand for the lesf in practically all cigar-producing countries of the world. It hes always been sold almost exclusively in the Netherlands. Only the very low grades that cennot be used except for wrappers on very cheap cigars are sold locally or exported to oth $=r$ ports. Cigar makers in the Netherlands Indies who wish to buy the batter vrapper oualities of Sumatra le f must purchase them in Amsterdem and ship them beck to the islands.

By 1872 the annual production of Sumatra wrapper tobacco had ircreased to over 1,000,000 pounds, and by 1380 to over 10,000,000 pounds. In 1890 the production wes ibout 43,000,000 pounds, which wis a record crop and wes not exceeded until 1899, when ebout 48,000,000 pounds wore produced. Betreen 1900 and 1918, production rang d between 40,000,000 and 52,000,000 pounds innually. it declined sharply in the post-wer y-ars 1919 to 1921, and averaged only sbout 28,000,000 pounds annually. The 1922 croo ws meterially larger than that of 1921, and from then until 1931 production ev ragad bout 41,000,000 pounds annually. From 1932 to 1938 , production ranged between $28,000,000$ and $31,000,000$ pounds annually:

Throughout the entire history of Sumetre wropper leef its gurlity has been m-inteined and it has al ays been considered among the best wroper types in the world. The leaf is very thin and elastic, which results in a lerge number of wropers per unit of weight. It is light greenish brown to brown in color and burns to a white ash. 
There are probably few plnces in the world suited for producing leaf with characteristics and quality similar to sumetra wrapper, and there re few places where greatur care and scientific reseurch is followed in tobacco growing. Production has always been in the hands of a few large, well-financed companies, which have employed highly trained production managers. In addition, the compunies have maintained a research organization and exporinent station, which serve the entire district. This organization is divided into departments that are continually studying the soil of the ciistrict, varieties of tobacco, tobacco diseases, insect control, and cultural and curing practicus. Fich department is headed by a highly trained technician, who works in connection with the estate managers in improving the quility of the leaf. The companies also maintain overhesd associations, one in the Netherlands and one in Sumatra, which devote their entire time to economic investigutions and give advice regarding production costs, labor supply, rn rket outlet, snd probable demand for verious quilities of the leaf.

Tyres of Sumatra Wrapper Tobacco: Sunatra wrapper tobacco his not always been a distinct type or variety. The soil and climatic conditions under which it is grown have resulted in uniformity of the leaf as regards color and texture, which hos enabled it to be classified commercinlly as a sinte type, but botanically it has until recently been a mixture of types thot could be separated into several strains.

In 1908 investigations mede by L. P. De Bussy showed that the tobacco is not a true breeding species but a mixture from which separate types can be segregated. He segregated c precocious strain, which flowers about 10 days e.rlier, hes a lower number of leaves, and thinner stalks of less height than the average tobacco in the district. He ws also able to extract a type or variety with coarse leaves and of slow growth and one having many laves and reaching a height of nearly 17 feet. If

\section{in 1903}

Experiments begun/in the United States with Sumatra wrepper leaf enabled the invostignturs to conclude that there were as many as eleven very distinct forms of the plants, sufficiently different to be designeted as incipient varieties. 2/ These investigations, however, cre conemhat discredited in the Netherlands Incies due to the fact that the seeds used vere from plants grown in the United St tes, and not directly from Sumptra. It is believed possible that sone cross fertilization might have teken plece and some of the types segreguted might have origin tel frum crosses with Anerican types.

In 1914 further investications of types were made in Sumatra and it was found that there were at least six distinct types. Those previously segregated by De Bussy were found constant for most typical charcteristics but not for all other factors. Trueness to type of succeding generations from the other types segregated was not proven.

In the years preceding 1920 considerable attention was given to seed selection with a view to improving an further standardizin sumatra wrapper leaf. By that year several of the est tes were using only seed that woula

1]Honing, J. A., 1915, "Deli Tobnceo a ilixture of Types,"Druk Vin J. H. De Bussy, rmsterdam.

2/ Shamel, A. D.,1906 "New Tubecco Varieties,"1906 United Stetes Department of AEriculture Yeer Bock, piage 387. 
prociuce a type is true as can be ubtained by seed sulection. By 1926 all of the estates were using selected seed, and by 1938 they were using seed from only four strains of the typical sumatra type, each strain havine only minor mutational differences.

Soils: Soils in the Sumatra wrapper-tubacco district apparently have greater influence in fixing the cummerial characterisitics and quality of the lieaf than other factors, such as varieities, climate, and cultural and curing practices. The soils are all primarily of volcanic urigin, rich in minerals anc underlaid with older marine rocks or sediments, of which there are outcroppings at certain points. They vary in color from red to brown, and grey tu bleck, and in texture from clay loams to sandy loems. They each have an acic reaction but some are unly slichtly acic, pH reaction number ranging from ab ut 5.3 to 0.7. I/ Eisht distinct soils have been recognized. Five are strictly volcanic soils and have been petrographically designated:- lipariticdacite, liparite, dacitic mud-streans, dacitic and andesitic mud-streans. Two of the remaining three are alluvis soils, one beins derived fr m liparitictuff and one frin dacitic-andesitic tuff. The romaining type, of which there are only limited areas in the tobicci district, is soil derived from marine rucks and sediments.

The different soils vary substentially and there is a pronounced difference in the quality of tobaco srown on then. Certain of them are also more susceptible than others to tobicc plant disesses. This is particularly true as regards Granville wilt, knom in Sumatra as sline disease, which does greater damage in the Sumatra-wrapper district than any other. The accompanying figure 2 shows the location of the different soils and also the boundary in 1937 of the area in which Sumatra wrapper leaf tobacco was grown.

It will be noted that soils ajerived from volcanic tuff are farthest from the coast. The district in which the soils are found is a low plateau extending into the foothills. The alluvial soils are near the coast and have been formed by streams flowing from the sections of volcanic soils. The soils within the district derived from marine rocks and sediments are not suitable for tobacco and are limited to outcroppings in the volcanic-tuff soils.

The following is a description of the different soil types, their susceptibility to Granville wilt, and average prices received at Amsterdam for the leaf grown on them from 1893 to 1930. The prices offer an indication of the quality of leaf obtained from the different soil types.

Iype 1 - Iiparitic-dacite is a red-clay loam with a pH of 5.7 to 5.8 . Granville wilt on the soil is moderate to bad. It produces tobacco of average quality, which, during the period indicated above sold for an average price of 1.51 guilders per half-kilo ( $\$ 0.75$ per pound). $2^{\prime}$

IT The $\mathrm{pH}$ is a measurement of acidity and alkalinity of soils, which indicates the hydrogen ion concertration. A neutral soil has a pH of 7 . Soils with a pH below 6 are decidedly acid, and those with a pH above 8 are decidedly alkaline. $\mathrm{pH}^{\prime}$ s from 6 to 7 , and 7 to 8 , indicate slightly acid or slightly alkaline soils. $2 /$ Converted to United States dollars at 55 cents per guilder, the rate prevailing during the years 1937 and 1938. 


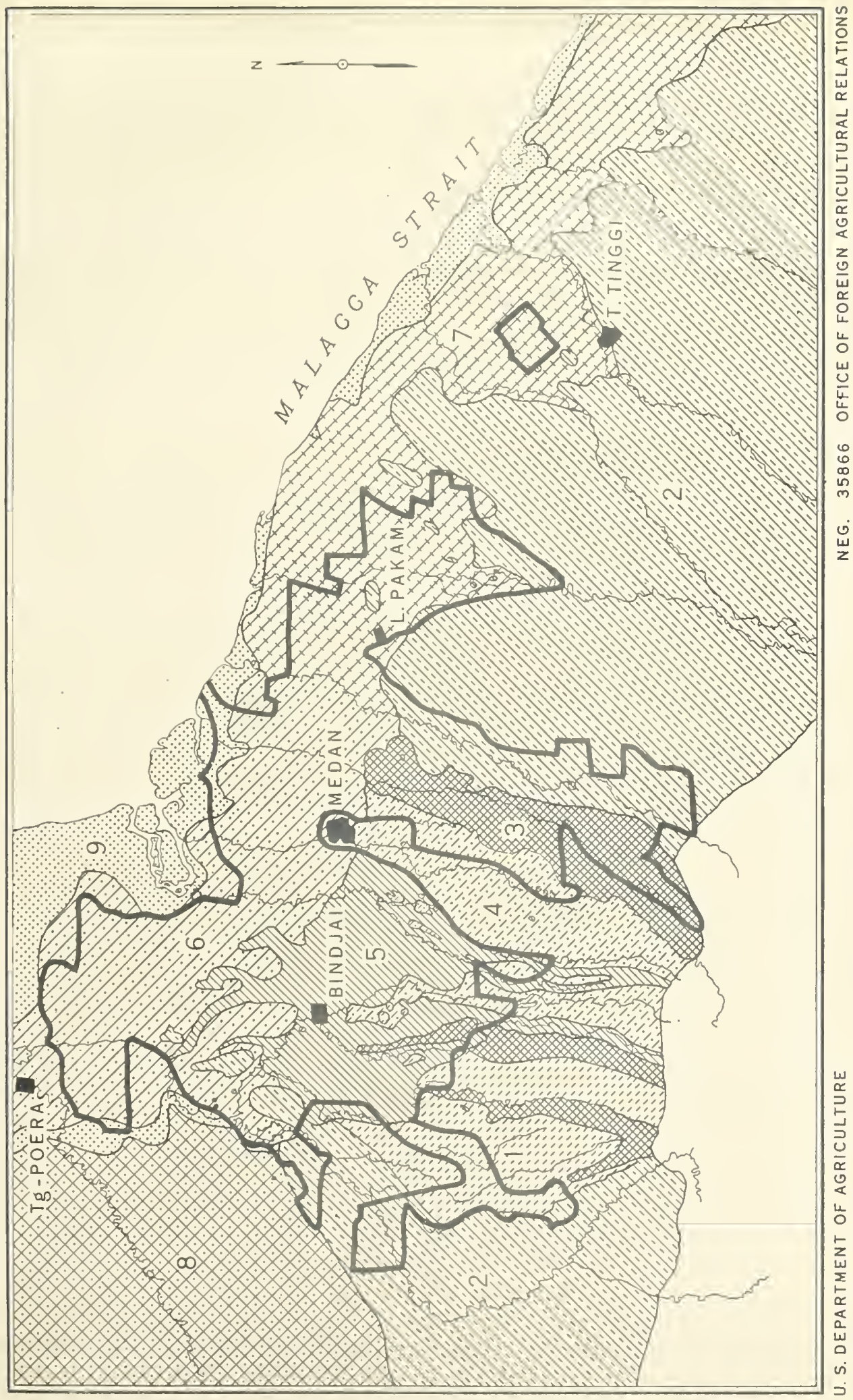

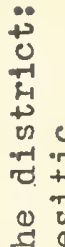

正

म

था मीन क

§.

का है E

न त्र

每造

品 - r

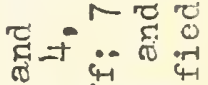

in 41 का का

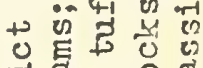

क्ष 0 व

कै का का ए

थ) फ

- I v

○目宅

ญ 0 ส

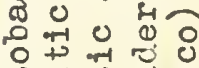

+

4 क

क च व

न $E$ \&

H $M$ ह 영

शै क्ष ज्ञ

ठำ

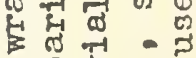

- $>$ i $\infty$

क्न न्न

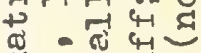

䛼门

ค ‥

4-1 +ै क्ष

0 정

द्व हु स्त

व

尊 $\begin{gathered}0 \\ \text { on }\end{gathered}$

है 1

ल स्न त्ञ

$1 \%$

i

त.

\& -1

है

F्य 
Type 2 - Liparite is a red-clay loam with a pH of 5.3 to 5.5. Granville wilt is moderate to bad. The tobacco grown is inferior to that from the other soils in the district, and the average price was 0.90 guilder per half-kilo (i0.45 per pound).

Type 3 - Dacitic mud-streams is a dark brownish-red sandy loam with a pH of about 6. The extent of Granville wilt in tobacco grown on it is irregular, in some places bad, and in others does not occur. It is the best tobacco soil in the district, and leaf grown on it sold for 1.99 guilders per half-kilo ( 0.99 per pound).

Type 4 - Dacitic is also a dark reddish-brown loam but with somewhat less sand than Type 3. It has a pH of 6.2 to 6.7. Tobacco grown on it is subject to greater damage from Granville wilt than that on any of the other soil types. Laf from the soil is below average in quality and sold for 1.34 guilders per half-kilo ( 40.67 per pound).

Type 5 - Andesitic mud-streans (black dust) soil is grey when dry and black when wet. It is a sandy soil with much silt and has a pH of about 6.5. There is no Granville wilt in tobacco grown on the soil except in places where there are outcroppings of subsoil derived from older marine rocks. Tobacco grown on it is somewhat above average in quality and the price has been 1.70 guilders per half-kilo ( $\$ 0.85$ per pound).

Type 6 - Alluvial soil derived from dacitic-andesitic tuff. It varies in texture from white clays to clay loams that are light to dark yellowish browns, and brown sandy soils. The pH varies, and is slightly acid to acid for each sub-type. Granville wilt is usually very bad in the clay soils, is limited in the loams and rarely occurs in the sandy soils. Tobacco from this soil type is as a whole of superior quality and the average price has been 1.81 guilders per half-kilo ( $\$ 0.90$ per pound).

Type 7 - Alluvial soil derived from liparitic tuff. It also varies from clays to sands that are quite similar in color to Type 6; however, it contains less minerals and is somewhet deficient in plant food. The $\mathrm{pH}$ and extent of Granville wilt in tobacco vary with the soils of different physical properties about as in Type 6. Tobacco from it is somewhat inferior in quality and the average price has been 1.10 guilders per half-kilo (w0.58 per pound).

Type 8 - Soil derived from marine rocks and sediments. It is quite different from the volcanic-tuff soils and is not used for tobacco. It varies from clays to sands and is usually alkaline in reaction.

Climate: Temperature in the district is relatively uniform throughout the year and the daily range is small. at liedan, wich is in the center of the district, monthly averages vary between $770 \mathrm{~F}$. in December, the coolest month, and $810 \mathrm{~F}$. In Wiay, the hottest month. The yearly average is $78^{\circ} \mathrm{F}$. Daily fluctuations throuchout the yesr average about $150 \mathrm{~F}$. They are greatest during the drier months February to April, and June to July than during other seasons in the year. Humidity is relatively high throughout the year. It averages 84 percent and varies between months from 82 to 35 percent. Rains are frequent, but sunshine is ample, averaging 60 percent for the year. 
Rainfall is relativ ly havy throushout the district. The yearly average precipitation betreen different stations varies materially, but seasonal flutuations are relatively uniform. Sections of highest rainfall are the plateau and foothills, and those of lovest, near the coast. The average annual rainfall of ten selected stitions in the district renges from 71.9 inches et Belidan to 157.1 inches at Petain. For the district as a whole, the average annual is about 103.5 inches, and monthly averages vary from 5.3 inches in Februery to 13.4 inches in Octuber.

Est ite Management and CuItural Practices: During recent years the entire production of Sumatra wrepper le f hes been grown by seven companies, of which four, known as the big four, have produced approximately 95 percent of the total. The companies have large estates, a total of 47 in 1937, which are lands held by long-term leases. I/ The total acreage of tobacco grown by the separate companies varies from about 200 acres in the cise of the smallest company to over 15,000 acres grown by the largest company. All of the companies grow some rubber and certain other plantation crops, but in most cases tobacco is the major crop.

The management of the estates is in the hands of Europeans, and a large number of laborers is employed for lield operations. In 1937, there were some 400 Europeans employed as managers and sub-managers, and on December 31, 1937,

I/ The metter of land tenure in the district is extremely complicated. "For planting tobacco the Europeens originally obtained land concessions of various sizes from the sultan of Deli. Some of these concessions were for 50, some for 75 and some for 100 years. These 'Sulten's Grants', as they have ever since been known, were rather informil transictions and were not drawn up in accordance with the provisions of the Netherlends Indian Civil Code. In the first place, the ecrliest ones were made at a time when there was practically no civil administration of Deli on the part of the Colonial Government, and in the second place, the Sultens, as natives, were outside the scope of application of the Civil Code. Thus these tarly grants vere (and heve remaincd) without any definite status in Netherlands public law.

"Vorious attempts were made to regulate this situation, the most important of wich was a law which went into effect on ivy 6, 1915. This law provided: (1) that when the Sultan issued land to parsons to thom the Civil Code applied, the transaction must be registered in conformity with the provisions of the Civil Code, and (2) that a prior condition of such i transaction must be the issuance of a declaration by the head of the local or provincial administration testifying to the Sultin's authority to make such a grant. But the Civil Code was not (and is now not) applicable to nitives and those heving the status thereof. Thus there are at present in existence three kinds of Sultan's Grants: (1) those made prior to the law of $1915,(2)$ those made subs auent to and in conformity with the law of 1915, and (3) those made to percons not subject to the Civil Code. These lust grants were not regist red with the appropriate office of the Netherlands Incian Government but with the Sultan's o:m native tribunals.

\section{"Extremely few if any of these Sult n's Grants were actually freehold} grants; there are only thrue of them in the present city of liedan. The very great majority were in the niture of long-terki les.seholds." (From unpublished report by Sicney H. Brown, American Consul at hiedan.) 
the total number of laborers employed was 74,405. Of these, 7,735 were contract laborers hired under contract for a period of 5 to 6 years for work on specific plantations, and 66,670 were free laborers employed on a daily, monthly, or piece basis. About 36,000 of the laborers were Javanese men, 27,000 were. Javanese women, and over 10,000 were Chinese men and women. Only a limited number of Sumatra natives are employed, as the intelligence and industry of these people are below those of the Chinese and Javanese. Foremen and supervisors are largely Chinese. The chinese also grade most of the crop. Laborers are paid according to wage scales fixed by the Deli Planters' Association (an Association supported by all companies in the district). Nages consist of a basic amount in cash, either on a day basis or at a piece rate. Slightly higher wages are paid for old hands than for new recruits, and wages for women are lower than for men. In 1937, the average cash wage for men was about 28 cents per day ( 0.515 guilder) and for the women about 16 cents per day ( 0.29 guilder).

Dormitories or barracks are provided as living quarters. for the laborers. In addition, they receive a discount on the purchase of foods and free medical attention. In 1937 these services amounted to an additional 3 cents per day ( 0.055 guilder $)$. In many cases the laborers are also provided with land to be used as gardens.

The estates are large and well laid out. They vary in size from about 12,000 to over 50,000 acres. The land devoted to tobacco is carefully surveyed and laid off in blocks of fields. The average size of a single field is about 1.6 acres and it accomodates approximately 16,000 plants. The same field or block of fields is used for tobacco only once in 8 years. In most cases they are cleared ot timber, the timber being burned off and tobacco immediately planted. Tobacco is grown in the spring months and is followed in the same year with a crop of rice.

The planting dates for tobacco in different sections of the district vary in accordance with altitude. In the upland sections seedbeds are prepared in December and in lowlands during the second week in January. Transplanting is done from 40 to 45 days after the soring of seed beds. Harvesting extends from April until June or about 90 days after transplanting.

After the rice crop following tobacco is harvested the land is usually allowed to grow back to jungle and is not disturbed for 7 years, when it is again cleared and plinted with tobacco. The only exception to this procedure is on some of the land where Granville wilt is bad. The estates in these sections plant pert of their fields to Mimose invisa, $\varepsilon$ tropical leguminous plant which has the appearance of vetch. Fields planted with wimosa invisa for the 7-jear period between tobacco crops are found to be free of Granville wilt. I/

I/ The full significance of Wimosa invisa in checking of Granville wilt is not known but it is generally believed that its effectiveness in this respect is due, (1) to the fact that it is not a host for the bacteria causing the disease, (2) that it has a rank growth and checks the growth of weeds that would be hosts for the bacteria, and (3) that it improves the soil stmucture which results in a greater development of numerous kinds of soil micro-organisms, some of which are spparently destructive to the bacteria causing the disease. The latter theory is siuported in part by the fact that liming of the land, which improves the soil struct,ur?, also checks the disease; however, lime reduces the acidity of the soil, which may be a mears of checking the growth of the disease hacteria. 
Leaf from such fields, however, is considered jnferior in quality to that grown on jungle land. It tends to be coarser and many planters believe somewhat darker in color, both of which are objectionable qualities.

Seedbeds are laid out on freshly cleared land that has been built up to a height of about 1 foot above the original level. Steam treatment of the beds for disease control is a common practice on some estates, but others do not use any form of seedbed sterilization. The beds are well fertilized and are covered with a light muslin at a height of about 3 reet (see figure 3). This is to prevent damage to young plants by heavy rains and sunshine. When the plants approach the size at which they are transplanted the covers are removed.

The fields to be planted with tobacco are laid off in double rows about 40 inches apart with small ditches between them and large drainage ditches at the end of the rows. The transplanting of a single field of 16,000 plants is done by sections over a period of about 3 weeks so that the leaves will ripen progressively.

Practicaily the entire process of cultivating the crop is by hand. Animals or tractors are used for making ditches between fields but il other operations are by hand. The rows and ditches between them are prepared with heavy hoes or mattocks and cultivation is with hoes.

Plants in the seedbeds are sprayed about five times with a liquid arsenate of lead spray. Two applications of the same spray are also made within 10 days after transplenting. Following this the plants are dusted about every 4 .days with a mixture of soil and 5-percent arsenate of laad powder, or, as has been the practice in the past few seasons, soil and 5.5-percent bariumfluosilicate. Worms not destroyed by spraying and dusting are caught by hand. This work is done by women and children who work on a daily wage basis, or are peid about 11 cents for each 100 worms they catch.

Fertilizers are extensively used. A small portion of guano fertilizer is placed in holes in which plants are set. Phosphate is applied in the form of basic slag. The potash requirement is usually supplitd in the form of ashes from tobacco stalks; however, sulphate of potash is used in the darker soils that are low in potash.

Miost of the plants are topped when the flower begins to form; however, the portion of the crop on land thit tends to produce a heavier leaf is allowed to bloom and seed. The crop is harvested by prining and as a rule only two leaves are taken from each stalk every 2 days. Grut care is taken to prevent the leaves from being broken. They are corried in baskets by hand to curing barns adjacent to the fields and priming is done only during the morning when the dew is heavy.

Curine: The curing of Sumatra wrapper leaf is accomplished by air-curing followed by sweating or fermentation process. The curing sheds are constructed of poles with a mof of palm leaves. The sides and ends are formed by continucus rows of doors made of bamboo splints, which can be opened for ventiletion (see figur 4). The sheds are constructed so that they can be torn dom and rebuilt at veriois plices on the plantiation is the hlocks of tobacco fields are rutated. 
For curing, the tobacco leaves are strung in the morning or late evening on strings of which each end is tied to i bamboo pole. Each lear is examined before stringing. Worms or insects are picked off and demaged leaves are removed and cured seperately. The strings of leaves hang in the sheds from 18 to 22 days or until they have become dry. During this period the ventilating doors are regulated to assure proper ventilation and to prevent excessive dampness and heating. During the damp periods, most of the ventilation is shut off during the night and early morning, and wood or charcoal fires kept going in order to prevent excessive humidity. When dry, the strings of leaves are removed from the bamboo poles and each string tied into a hand. The hands are then placed in baskets and hauled to the plantation's fermentation shed. This is only done in the early morning or late afternoon when there is less danger of the leaves being broken.

The fermentation sheds are closed, relatively dark buildings, with little ventilation, but adjacent to them are well-lighted grading and sorting rooms. Tobacco brought to the sheds is weighed, and hands of leaves of uniform quality are assembled to be fermented in a shingle block. This latter process is simplified by the removal of inferior leaves, when they are strung, and further by the fact that harvesting and curing are so regulated that leaves from the same position on the plant arrive at the fermentation sheds together.

Fermentation of the leaf is accomplished by four sweating processes. For the first sweating of a quantity of tobacco the leaves are piled into eight rectangular bulks vith rounded corners, the outside wall being formed by placing the hands with their butts to the outside (see figure 5). The bulks each contain about 4,000 to 6,000 pounds, the size being governed by the quantity of leaves of similur grade arriving from curing barns. The bulks are allowed to stand for about 5 days, during which time the temperature at the center rises to about $129^{\circ} \mathrm{F}$. They are then repiled into four larger bulks, each compised of two of the original small bulks. The sweating or heating process again occurs, but usually requires approximately 3 alys longer than the first sweating. This process is followed by two rnore sweatings, one in which the tobacco is piled in two bulks, and the last in which it is piled in one bulk. The last sweating requires about 18 to 20 days.

rith each repiling, the honds of leaves are shaken out and well aired. I/ In building the next bulk int which they are pleced, the hands in the outside of the previous bulk are placed in the center. They are also reversed from top to botton.

1/ The Deli Planters' Association, fror funds raised from all of the companies in 1937, installed an ordering nachine as an experinent on one of the plantations. The machine provides for temperature and humidity control, air circulation, and a shaking process that does less damage in the breaking of leaves than the hand method. The operation of the machine requires almost as much labor in loading and unloading as is required by the hand method; it is also an expensive installation, and in 1938 did not prove to give a better curing of the leaf. It is, therefore, doubtful if it will become of generaI use. 
The following tabulation shows the actual dates on which bulks were made, when they were broken, and the temperatures attained in the fermentation of a quantity of sand leaves in 1937.

A. Bulks (4,409 pounds) B. Bulks (8,818 pounds) C. Bulks (17,636 pounds)

$\begin{array}{lllll} & \text { Tempera- } & \text { Tempera- } & \text { Tempera- } \\ \text { Date Date ture date } & \text { Date } & \text { Date ture date Date } & \text { Date. ture date } \\ \text { begun } & \text { ended ended OF } & \text { begun } & \text { ended ended }{ }^{\circ} \text { begun } & \text { ended ended OF }\end{array}$

$\begin{array}{lllllll}\text { 1.Apr. } 11 & \text { Apr. } 16 & 129.2 & 1.4 p r . & 17 & \text { Apr. } 20 & 129.2 \\ \text { 2.npr. } 11 & \text { Apr. } 16 & 128.3 & 16\end{array}$

$\begin{array}{lllllll}\text { 3.Apr. } 14 & \text { Apr. } 19 & 129.2 & \text { 2..ipr. } 20 & \text { Apr. } 28 & 129.2\end{array}$

1.Apr. 28 May $12 \quad 127.4$

$\begin{array}{lllllll}\text { 5.Apr. 17. } & \text { ipr. } 22 & 128.3 & \text { 3.Apr. } 22 & \text { inay: } 3 & 129.2 \\ \text { 6.4pr. 17. } & \text { 4pr..22 } & 130.1 & & \end{array}$

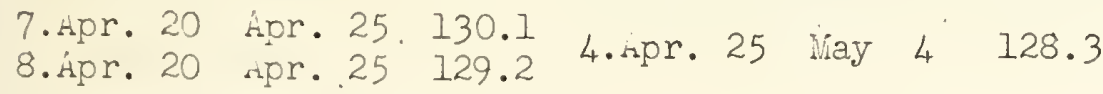

2. May 3 ivay $17 \quad 128.3$

D. Bulk $(35,274$ pounds $)$

T'emperature at different places in the bulk oF

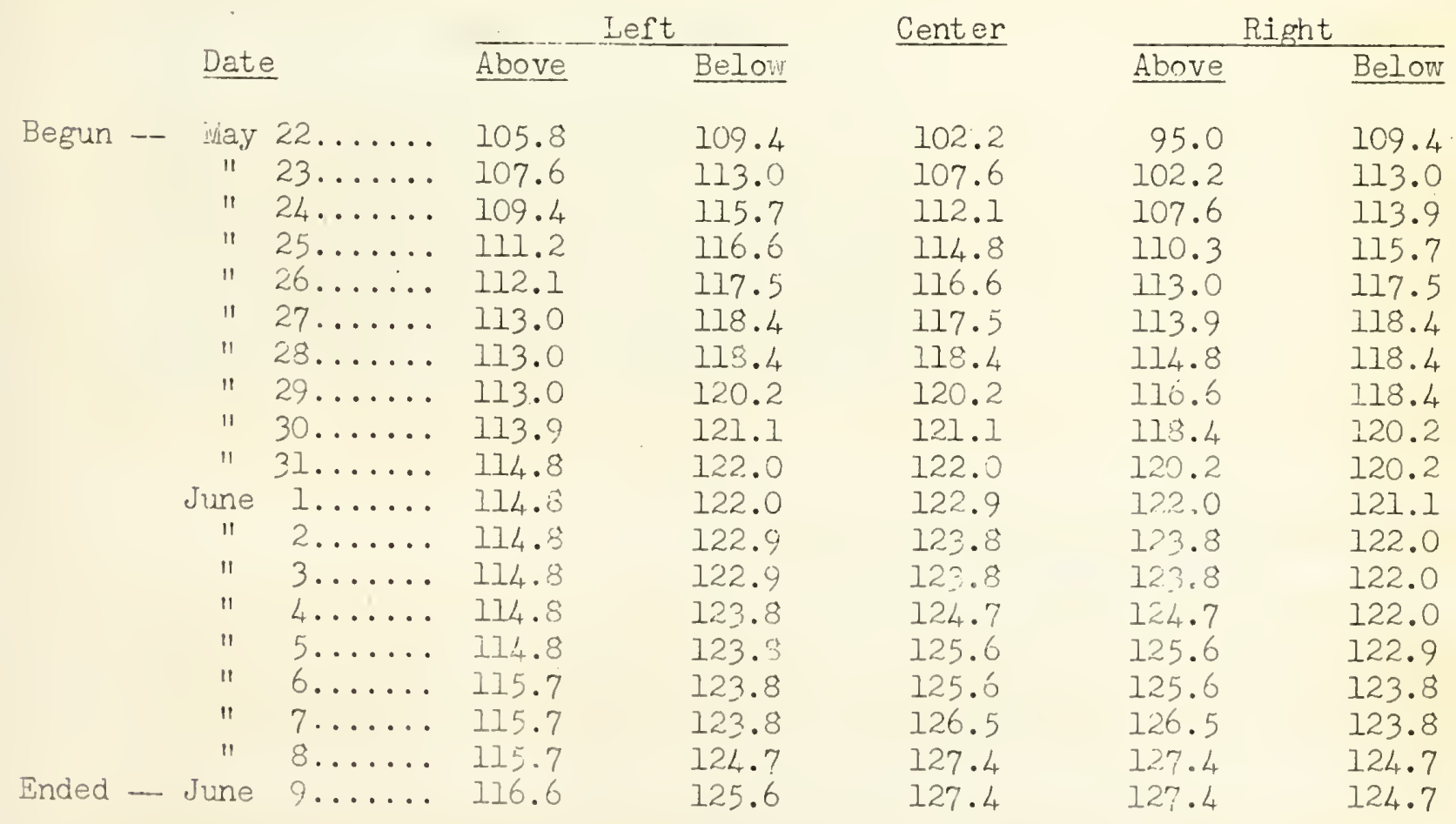

Cost of Production and liarketing: Detailed information regarding cost of producing and marketing Sumatra wrapper leaf is not obtainable. Statenents obtained from estite managers in the district in 1938 were to the effect that 
total cost of production and delivery to the Netherlanas, all overhead expense included, for the years immediately preceding 1938 was about 1.13 guilders per pound, or at the average exchange from 1934 to 1938 about 70 cents per pound. This in terms of guilders is about equal to the average costs of a single conpany for the years 1932 to 1935 and agrees approximately with average costs in 1935 and 1936 of the four leading producing companies as derived from financial statements of the companies.

Table 5.- Prices received, cost of productjon, including delivery to the Netherlands, and net profit of a single tobacco company in the Sumatra wraper leaf district, 1932 to 1935

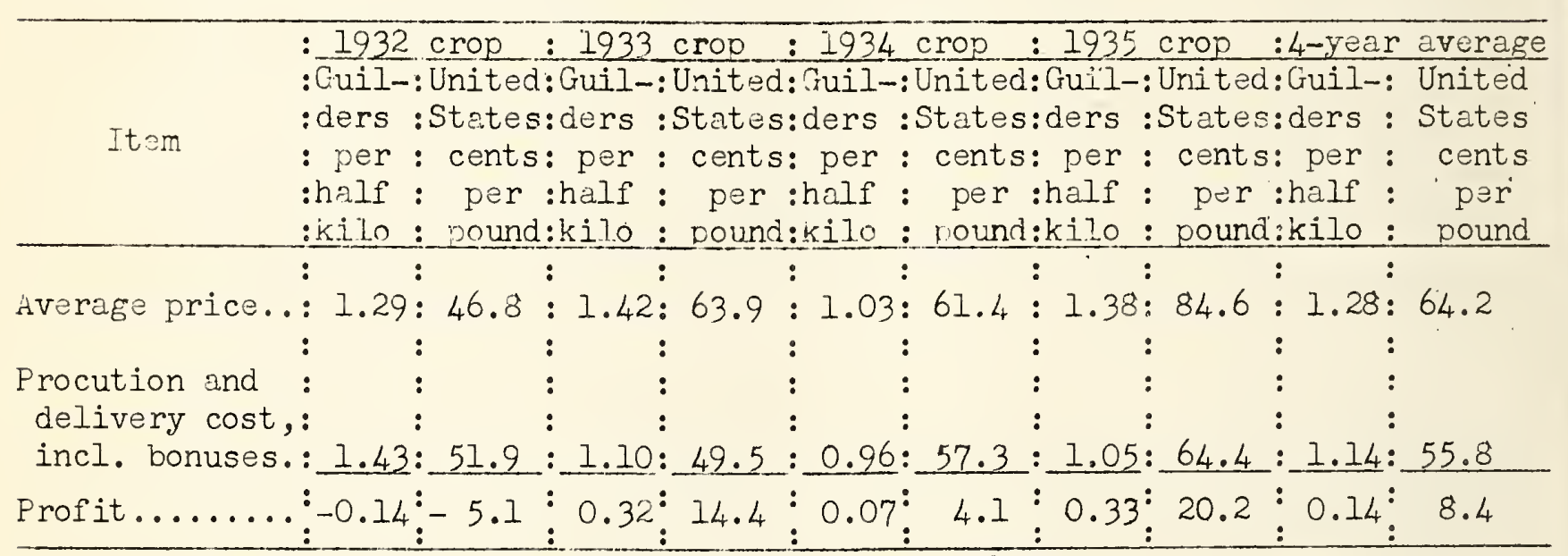

From unpublished report of American Consul Brown at iledan.

Total returnsfrom tobacco sales, dividends paid and changes in reserve funds of four companies which produced over 90 percent of the crop in 1936 and 1937 indicate that production costs and delivery charges to the Netherlands averaged 1.11 guilders per pound in 1935 and 1.10 in 1936. Prices received by the companies average 1.37 and 1.24 guilders per pound respectively, which gives a net profit on the 1935 crop of 0.16 guilder per pound and 0.14 guilder on the 1936 crop. These estimates sre subject to error as the financial returns of the companies do not give details regarding improvements in plants, etc., which perhaps should not have been charged agiinst the crops concerned; however, they support the reported average cost of production of about 1.13 guilders per pound.

\section{Sumatra West Coast (Native Tobacco District)}

Native Kerf tobacco is produced throughout the island of Sumatra but the west-coast district near the port of Padang is the only area where production substantially exceeds the demands for local consumption. It is the principal district from which exports originate and from which Sumatra kerf tobacco is shipped to other islands of the archipelago.

Sumatra native tobacco is grown entirely by natives and the acreage per grower is very small, sometimes linited to a few rows in his garden. Total production on the island is approximated at about 10,000,000 pounds annuelly and it is believed that something nesr half of it is produced in the west-coast district. The crop is grown throughout the year but production in the west-coast district is largely during the summer months. 
Figure 3. - Sunatra rrapper-leaf seedbeds.
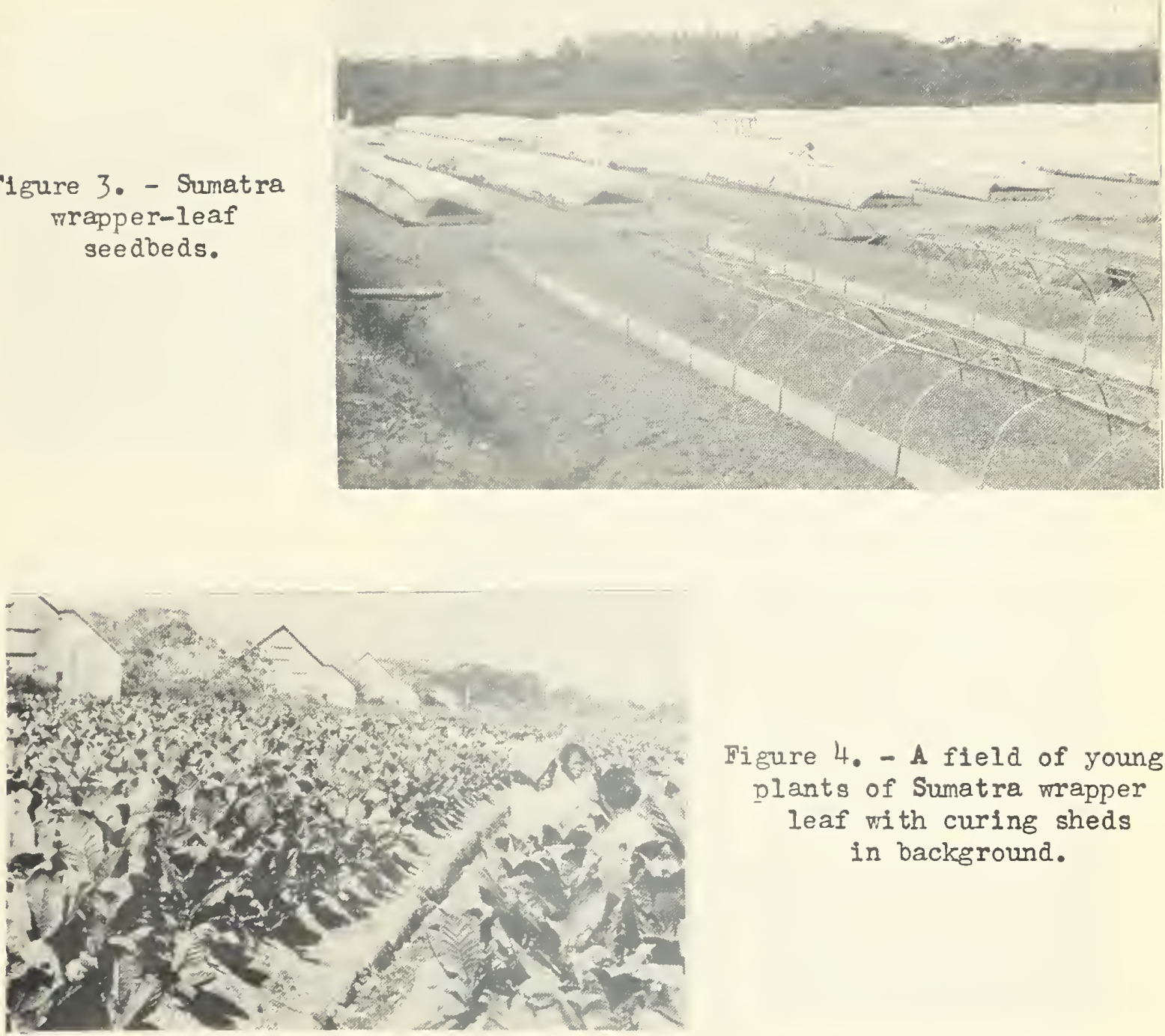

Figure 4. - A field of young plants of Sumatra wrapper leaf with curing sheds in background.

Flgure 5. - Bulks of Sumatra wrapper leaf in fermentation sheds.

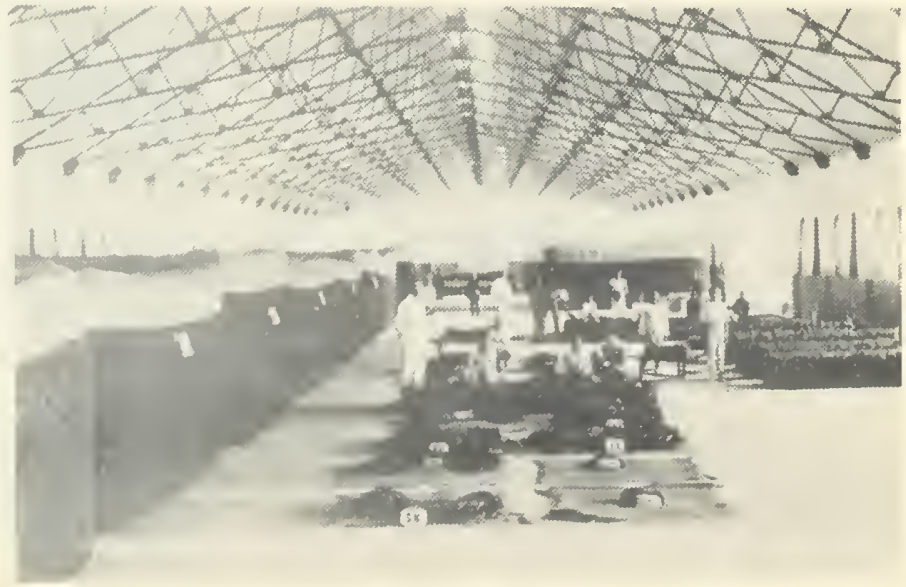


Figure 6. - A field of native Java tobacco.
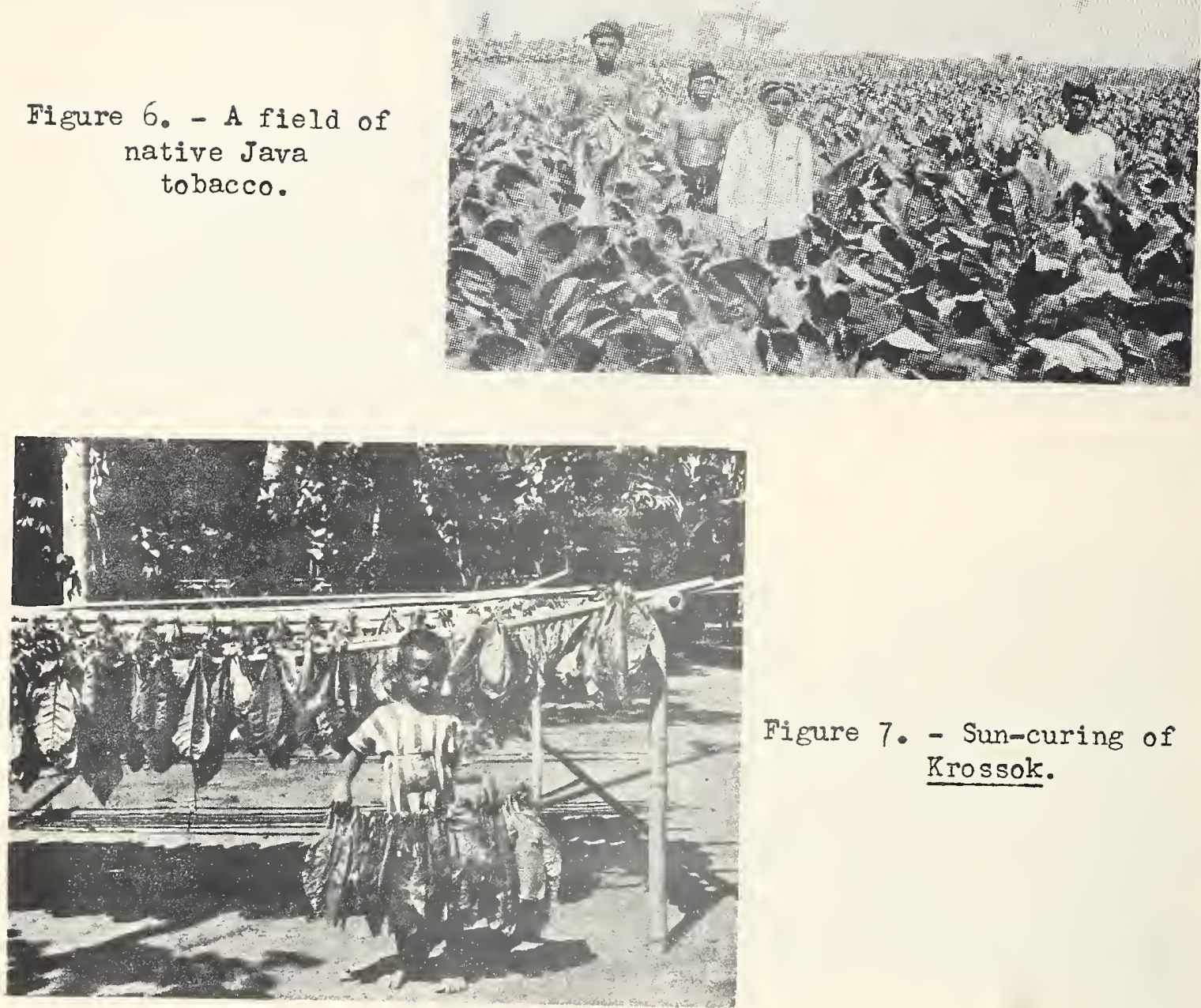

Figure 7. - Sun-curing of Rrossok.

Figure 8. - Shade-curing of Krossok.

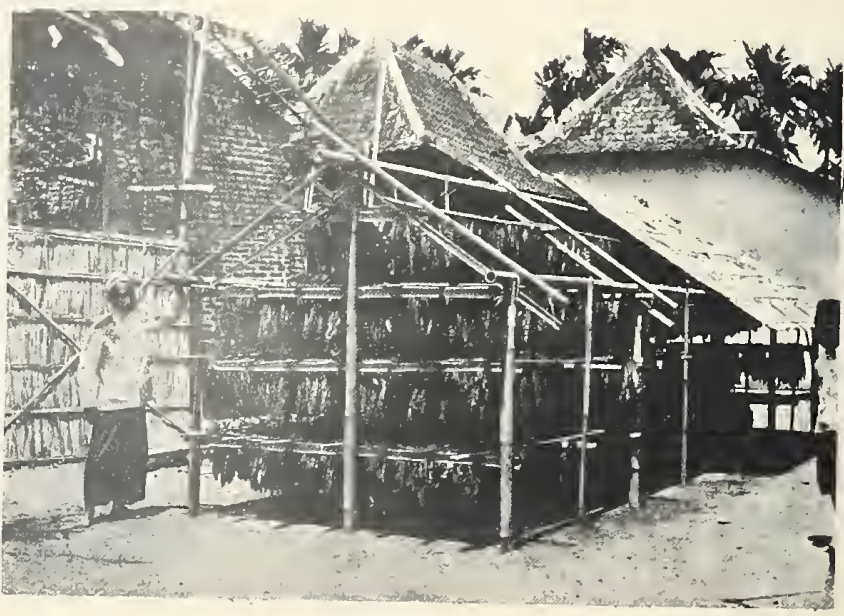


Terne ratures in the district averuge slinkly higher than those in the east-coast district of Deli. The relative humidity is lover but average annual rainfall is nigher and the seasonal variation sonevhat different. The everage annual precipitation is about 139 inches. July and susut, the nonths when most of the tobacco is being harvested and cured, is the period of least rainfall. Durine these months precipitation averages about 7.5 inches. Rainf II is substantially greater during other months oi the year and is nighest in Novenber with an average of 17.1 inches.

Soils in the district are largely derived from a rixture of older mine rocks and younger volcanic naterial. They are neutrel to slightly acid in reaction. The tobacco grom on them is hecvy-bodied and has a strong arona. The culturel practices vary meterially. In 2 fer cases the cror is planted directly in the field; however, seedbeds are usuelly used. Definite rotations with other crops are not followed. The tobicco is often grown year aft $r$ year on the same land with no intervening crops. If a crop is planted between the crops of tobacco it is usuilly red peppers. It is not uncommon for as miny as three hirvests of tobacco to be tiken froin the seme plant. This is accomplished by allowing suckers to grow from the stalk after wech priming.

Curing prectices followed in the district, and wich are seneral for Kerf tobacco at all other placcs in the iretherlends Indies, are relatively uniform. The green loctes ar first tied in bundes of about 50 lectes each, where they rosin from 1 to 5 diys or until desired color is developed; 1 dsy in case a yellow color is desired and 4 to 5 doys for d rk colorine. Followine this process the leaves are shredded with l-rge knife and wre sprend in the sun on bumboo matting until dry, which rucuires 4 to 5 diys. The barboo inattings holding the shredded letves ro usu lly carried indoors nisht; honever, it is generil in the case of light tobacco for than to be left out in the night dew 2 or 3 hours each night, na for the drk tobacco to be left out in the dew 1 or 2 whole niehts. The tob cco is reacly for consurption inadictely after curing, but the better grades re ususily stored or gid for a fev ronths, during which tine the product undergoes a fimentation process.

Lisht tobscco cured by the cbove process is used in cigarettes and strootjes and the dark tobacco in strootjes and chewing tobecco.

Vorstenlinden Jeve. (Cigar Tobacco District) I'

Vorstenlanden cigar leaf wich is rovn in middle Jnve is considered tho best Java cigar tobacco. Its production sterted before th t. of Sumitra urepluer loaf but since 1874 the output has always been beloin the production of Sunctra wrapper leaf. Fror 1875 to 1892 production ranged bet:een 1,200,000 pounds and 3,600,000 pound annually. It ws increased substontially in 1893 and the yours immedictely followin. By 1913, the peck yon in production, it totaled ebout 32,000,000 pounds. Production declined sherply curing the world wer but sine1921 has ranged betwen $19,200,000$ and $26,900,000$ pounds nnnuelly.

I'As in other ports of centril and est Juve, soje nitive kerf tob:cco is produced in the Vorstanlinden district. Its connercin inportince, howevir, is limited. Its cultiv tion nd curingare ossentilly the sine is practiced in the Suritra irest Coast District. 
Vorstenlanden cigar leaf is not considered eciual in quality to Sumatra cigar wrapper leai. It is used primarily in cigars as wrapper, binder, or fi]ler. Small quantities of the lower grades are used in pipe tobacco. Furchases for use as cigar wrappers are largest in years hen the leaf happens to be of especially good quality and when the quality of Sumatra wrapper leaf is below average. The leaf has a darj-brown or redish-brown color and fine aroma. irost grades are moderately thin but in generel lack the elasticity essential for wrapper leaf.

Practically the entire production of Vorstenlanden leaf is on volcanic coils of comparatively recent origin located at the base and on the slopes of ivount iverapi. The soils are composed of grey volcanic tuff thet has been vished down from the Merapi volcano. They are sandy loam in texture, are rich in minerals and slightly acid to acid in reaction.

Temperatures in the district do not vary materialy throughout the year. Nonthly averages at Klaten, a town near the center of the district, range from $770 \mathrm{~F}$. in February, the coldest month, to $8 \mathrm{CO} \mathrm{F}$. in October, the hot test month. The yearly averag: is $780 \mathrm{~F}$, the yearly avurage maximum $88^{\circ} \mathrm{F}$., cind average minimum $720 \mathrm{~F}$. Humidity is high during the riiny nonths, Hovember through June, when dverages range between 82 ind 89 percent, but it is lower during other months of the year, when it averages around 75 percent.

Rainfall is relatively uniform throushout the district. Varicitions in yearly annual precipitation betvien ten selected stations rene fron 61.2 to 92.1 inches. The yearly rainfall for the district as a whole is below that of most sections in Jeva and averages 78.5 inches. Thare is a decided seasonal fluctuation in rainfell. It is relively heavy during the late fall and winter months, averaging 13.0 inches. in Februsry, and low during the summer months, averaging onl.y about 1.2 inches for each of the nonths of July, Ausust, and Sept ember.

Vorstenlanden liaf is grom exclusively on estates of leased land that are controlled and menaged along lines very similar to those followed for sumitra estates. For the past few years production hes been in the hends of eight companies, of hich two hive grom about two-thirds of the crop. The eight conpanies lease a total of 20 or more separate estates ind the area devotad to tobacco since 1920 has reneed between 14,300 and 19,100 acres. The tobacco 1 ands are leased from the tio suitantes in the district for long-teri periods, usually 50 years. The leases birid the companies to an exact procedure as regards the use of land. Tobacco can be cultiveted only once in 2 or 3 years. Batween tobacco crops, rice and other crops Ere grown by natives ind without the supervision of thi estre compenies. The leases are so written that the companies pay yuarly rentals only on the land actually planted to tobicco. Yuariy rentals for the years thit the land is used for rice and products other thin tobacco sre collected from the natives who srow those crops.

The comparies as a group maintain overhead organizations, and an experimental station, which are similar to the institutions maintained by the Suratra wrapper-ieaf companies. Production is corried on on a highly scientific basis and methods to improve quality are sought continuously. 
The crop is grom from July throush October and harvested in Novenber and December. Cultural and curing practices in the Vorstenlancien district compare with those of the Sunatra wrapper district except for such differences as are necessitated by varying conditions. One of the principal differences is that irrigation is generally used; however, in most suasons rainfall is suifj.cient except during limited periods. Irrigation is used only when it is necessary to keep the crop growing normally. It has been found that leaf grown with irrigation is coaser and in general inferior in quality to that grown when rainfall is anple and irrigation is not used; as a consecuence irrigation is kept at a minimum.

Eanjoemas (Cirar Filler and Binder District) I/

The Banjoemas district is a small aren in central java, east of the town of Eanjoemas. The prociuction in this district of tobacco of sufficient quality for export or use in domestic cigars has in recent yoars averrged between 1,500,000 and 2,500,000 pounds annually. The leaf is comprrable in types with Vorstenlanden cigar leaf and in years of ample rainfell thi qualit, is sonething neir that of Vorstenlinden leaf.

Soils in the district are rea or brown lateritic earths derived from crystalline schists and metamorphic rocks, or from andesitic rocks ind breccias of the tertiary age. They are sandy to sondy locm in texture. Tenperatures in the district are relatively uniform throughout the year. Relative humiaity and rainfall have sasonal fluctuations comparable with those in the Vorstenlanden district; however, the average rainfall is higher than in Vorstenlsnden and averagas about 151.1 inches. December, with an average rinfill of 21.6 inches, is the wettest month and August, with an average of 2.6 inches, is the driest.

Tobscco for export from the district is grown from July through October and h:rvested in November and December. Its production is largely in the hands of a few estates; however, some tobacco erown by natives is purchased by estate owners and cured and fermented by them. Production and curing practices on estates are somewhat similar to those in the Vorstenlanden and Sumatra wrapperleaf districts.

Kedoe (Cifar Filler and Natjue Tobacco District)

The kedoe district is in central Java between the Vorstenlanden and Banjoemas districts. In recent years, total production of Krossok in the district, of a quality suitable for export or for use in domestic cjgars and cigarettes, is believed to hav averaged between 10,000,000 and 13,000,000 pounds annually. 2/ In addition there is a substantial production of Kurf tobacco.

Thu tobacco in the district is erown entirely by natives. It is a general practice for the lower liaves on the plant to be primed and air-cured into Krossok, and the leavos higher up on the plant prepared into herf tobacco.

I/ Some native Kerf. is produced in the Banjoemes district. It is handied the sane as in west Sunatra and in Vorstunlanden Javit except that in mountain districts where sunshire is linited the shredded tobacco is cured over firos. 2) The terin Krossok in general denotes tob:cco that is produced and cured by natives in leaf form. 
The Kedoe Krossok is a relatively small leaf tipe, hewvy bodied, with a frir anount of oil and gum, but has little stretch. It is dirk brown in color and has a strons aroma. In Europe it is used primarily for cigar filler, but in the Netherlands Indies considerable quantities are ciso used in ciarattos and strootjes. The leaf is decidedly jnferior in quality to Vorstenlinden ind Banjoemas leaf. Kedoe Kerf tobscco is used only in doristic cigarettes, strootjes, cigars, and for chewin purposes.

Production in the Kedoe district is largely on soils derived from volcanic tuff of earlier periods. They are acid in reaction and have a hich mineral cuntent. Average znnul rainfall in the district is about 154.3 inches, and the seasonal fluctuation is somewhat sirilir to that of the Vorstenlenden district.

All of the Kerf tobacc and nost of the Krossck produced in the district is cured by natives. The Krossok is sold to local deslers for donestic consumption or export. There are, however, a few organizitions that purchase tha leaf from natives green or only pertielly cured nd comple the curing and fermentation processes. Production in the district is continuous throught the year, but late-suminer and fall crops represent over half of the total and account for most of the better quality tobacco.

\section{Besoeki (Ciecr Filler and Binder and Native Tobacco District)}

Tobacco is grown throuehout the residency of Besceki, which is located at the extreme eastem end of the island of J:va, but production is concentrated in the southwest district of the residency, which constitutes the Besoeki district proper. The crup in this district exceeds that of other districts in Java and it is apparently the area where tobacco production in Java began on a commercial scale.

As early as 1857 sales of Besoeki leaf in the Netherlands totaled approximately 340,000 pounds. Production probably greatly exceeded this anount, as the district has for many years been important in the production of tobacco for domestic consumption. For the 5 years preceding 1938 the total production of a quality suitable for export or for domestic use in cigars and cigarattes averaged about 45,000,000 pounds annually, of which approximately 32,000,000 pounds was grown in the southwest district. Production in the district is conprised of two general types: a dark ciger leaf for which the production in recent years has averáged about 25,000,000 pounds annually, and $\varepsilon_{2}$ lichter tJpe with an average annuli production of about 7,000,000 pounds. The cigar type ranges in color from brown to dark reddish brown. The leaf is thin, lacks oil and stretch, but has a fair aroma. It is used almost entirely for filier and binder. Its use as wranper leaf is restricted to snall quintities of the better grades used on low priced cigars. The light-tyre or native-type Besoeki tobacco is medium brown in color and according to American standards would be classed between our light and dark air-cured types. The leaves are relatively short and moderately thin. Oil content is low and the texture somewhat papery.

Production of the two Besoeki types is intermingled. The cigar type is grown exclusively on volcanic soils of recent origin and the lighter or netive type on both volcanic and lateritic soils, the latter having been derived from igneous material or andesitic rocks and breccicis. Temperature in the district 
is relatively uniform throughout the year and averages about 780 F. wisy is the hottest month with an average of $80^{\circ} \mathrm{F}$. , and July the coolest with an average of $760 \mathrm{~F}$. Average annual rinfall varias substantjally in different sections of the district but seasonal fluctuatjons are fiirly unifom throuhout the area. The average annual figures of ten selected stations range from 73.5 inches to 125.7 inches. The cverige of the ten stutions is 90.3 inches. Rrinfill is lowast in July, Aurust, and September whon ronthly averages for the district range nes 1.5 inches and is high st from December to Nirch when monthly averages are ibove 12.0 inches.

Tobacco in the Besoeki district is Erown throughout the year; howevir, most of it is produced in two distinct seasons. There is an aely crop known as Vooroofst tobacco, wich is grown and cured almost entirely by natives, and a late crop, of which over half cun be classed as estate tobacco. All of the tobacco rown by natives in the district is in generel supurior to other native tobicco of the island. iviost of it is cured into Krossok and lerge quentities ire exported; huwever, a part of the leaves frm the hicher nositions on the plant from both the early and lote crops grom and cured by notives are prepared as herf tobacc for use in domestic cigarettes, strootjes, and chewing tcbacco.

The early crop or Voprooset tobacco is planted in February and wreh and harvested in June and July. It is entirely of the lisht type and is grown only by netives on unirriested lend. The Krossok from the district is either exported to Furoce, where it is used larely for ipo tobacco, or is sold locally for use in unstic cigaretes and cienrs. The late crop grown during the second half of the ye:r on irrigated l:na, and whether produced by natives or under the supervision oi estate cumanizs, is larpely cisar tyre, most of which is exported to the Netherlands.

Cultural practices followed by natjves in the Besceisi district are decidedly better than those of nitives in most other sections of Juva con sumptra. The cuality of las is aecidecil suremior to most ntive tobacco but it is inferior to strict.J jate leaf. Cultural and curing nractices followed by natives are somuhit sinilar to tnose followed by est te omers; however, they do not use comiercia I fertilizers to the extent used by estates, insect cuntrcl is not so carefully carried out, and curing, in most cases, is done with less care than on estates.

Estate managerient in the Besoeki district differes materially from that in the Suratra and Vorsterlancien districts. It is siriliar in that the estate comanies maintain in orephead orginization and a research station. They also coperate in controlli.ng leaf pricus, wage scales, and the suply of leaf grown cnd narketea. Their land leases and labor arrangenerts, however, are materially disferent. Lind in the Besoeki cistrict is almost entirely in the hands of natives. Companies with so-called estates, of which there wer 15 in 1937 , Ifece tobacco land from natives usually for a noninal rent:l equivalent to the I... tom. In most cases, the lind is irrigated rice land and is only used for tomaco nnce in 2 or 3 years. The general prectice is for the companies to ar In through contracts for the nitives from whon the land is leased to grow J a cco for the:. Production by estate compunies through the emoloyment of hured labor is very linited. 
A native who produces leaf for an estate company obtains seedlings from the company. He is required to follow instructions of the company as to cultural practices, which in general are somewhat similar to those in the Vorstenlanden and Sumatra districts. The leaf when grown is, according to a previous arrangement, delivered to the company green. or after air-curing in sheds or barns owned by natives. The contracts also usually guarantee the native some compensation for his labor in case the entire crop is lost as a result of floods or other abnormal occurrences. All risis that can be classed as normal, such as danage from disease, insect pest, and an abnormal season, must, hovever, be taken by the native.

Leaf delivered green to the estate companias is air-cured in company-owned barns, the labor involved being hired by the company. The fermentation process that follows air-curing is also entirely at the expense of the company. The better grades of leaf handled in this maner are known as Blad (leaf); lower qualities are known as Hankrossok.

Leaf delivered to estate compenies after air-curing by natives is fermated by the company entirely at its expense. It is inferior in oucility to Blad and Hangkrossok and is sold under the designations Kampongkrossok or Krossok. I/

During recent years the research station, maintained by the Besoeki estate companies, and certain individual companies have conducted experiments in the district with American flue-curad type. Their interest in flue-cured has resulted from low prices during recent years for Besoeki Krossok and an increase in both domestic and export demand for light cigarette tobicco. Tricil plantings have given satisfactory results as to quality but production costs were substantially higher than those in the established flue-cured district of Java. Production in 1937 was limited to that from approximately 75 acres grown by a single estate company. The company planted a somewhat larger acreage in 1938, but there was no indication that other companies would soon take up production on a comparable scale.

Rembang and Kediri (Flue-cured and Native Tobacco Districts)

The Rembang and Kediri tobacco districts sre located in the eastern Jave residencies of Bodjonegoro and rediri. The Rembing district covers most of the central pert of Bodjonegoro residency and the Kediri district tine central part of îediri resiciency.

Native Tobacco: The production of native-type tobacco in the districts, and especially in the Rembang district, is large. It is inferior in quality snd somewhat comparable with Kedoe tobacco. During recent years the portion of the crop suitable for curing into hrossok has averaged around 15,000,000 pounds annually. The total production, includins that prepared as rerf tobacco, has been about 40,000,000 pouna's innuilly.

The bulk of Rembeng and Kediri native tobecco is light brown to light chocolate-brown in color. It is papery in texture, lacks oil and stretch, but has a fair to good arome. The Krossok from the crops is purchased by Europeans, primarily for use in pipe tobacco, and, in the cise of the French and Spanish monopolis, also for use in cigarette. It is considered by European buyers to

I/ The two terms Kampongkrossok and hrossok are nlmost synonymous. Kampongkrossok, which means village Krossok, differs only from Krossok in thet it is grown from seed furnished by estate companies and may therefore be somewhat superior to ordinary Krossok. 
be somewhat comparable with Maryland and other American light air-cured types. It is used in Java: in cigarettes. Kerf tobacco from the districts is used locaily in cigarettes, strootjes, cigar's, and as chewing tobacco.

The tobacco is grown on a variety of soils, but the bulk of prorluction is on lateritic earths, which in general are alkaline in reaction. They vary widely in color and texture but are predominantly brown or black clays and clay loams. Certain of them are similar to the adobe soils of the United States.

Like other sections of Java, temperatures in these districts ars relatively uniform throughout the year, averaging near $79^{\circ} \mathrm{F}$. Average annual rainfall in the two districts is approximately the same. Ten stations in the Rembing district and five in the Kediri district gave averages of 81.7 inches and 85.8 inches, respectively. Seasonal varjation in precipitation is also similar and compares with that in the Besoeki district. Average monthly rajnfall during July, August, and September ranges niar 1.5 inches, and monthly averages from December through warch each exceed 12.0 inches.

Native tobacco in the Rembang and Kediri districts is grown exclusively by natives and without supervision of estate companies. Production is continuous throughout the year, but a late-season crop accounts for inost of the total. The luaf for export and domestic cigirette menufacture is handled comewhat similerly to Besoeki Krossok. It is grown and either air-or sun-cured by natives and then purchased and fermented by devlers.

\section{American-type lue-cured: American-type flue-cured leaf grown near} Bodjonegoro in the Rerrbang district represents almost the entire flue-cured production in the Netherlands Indies. Production at all other points is as yet largely limited to trial plantings. If Expansion in production near Bodjonegoro is due primarily to the efforts of a single cignrette nanufrcturing company. 2/ Prior to the starting of flue-cured nroduction in the district, this company corducted experiments and trial planting with American flue-cured types at four widely scattered points in Java. Satisfactory results as to ouality were obtained at each point where trials were made, but the Bodjonegoro district was found to offer the best opportunity for expension. Soil in the district vas found to retain a high moisture percentage, which facilitates production and curing during the dry season, when best quality leaf can be obtained. Production costs, due to low land values and lower labor costs, were found to be below those at other places where trials were made. Returns to farmers for native Rembang leaf are below those for tobacco in other districts of Java, and natives in the district could be more easily induced to grow flue-cured than those in other sections.

If A number of estate tobacco companies whose estates are located at various places in Java have during recent years tried the production of flue-cured tobacco in the hope that it might be cconomically produced both for sale domestically and export to Europe. The Netherlands Indies Government has also become interested in the prospects for increased sale of Java flue-cured loaf. It began , experiments with the leaf in 1935, and in 1938 establish a flue-cured experimental farm in the Bodjonegoro district. They also plan trial plantings at numorous points in the island. The government's interest in flue-cured results from low prices and doreased exports of krossok in recent years. 2/ British American Iobacco Company. Following the laad of this Company, two other private agencies, one in 1935 and one in 1938, began the expansion of comexial production in the Bodgonegoro district. 
The district was further favored by the fuct that it is located adjacent to a railroad that has direct connections to nearby towns in which cigarette factories of the interested company are locoted.

Table 6.- Approximate acreage, production (farm wight), and price of tobacco from American flue-cured seed in Java, 1928, to 1938 a ${ }^{\prime}$

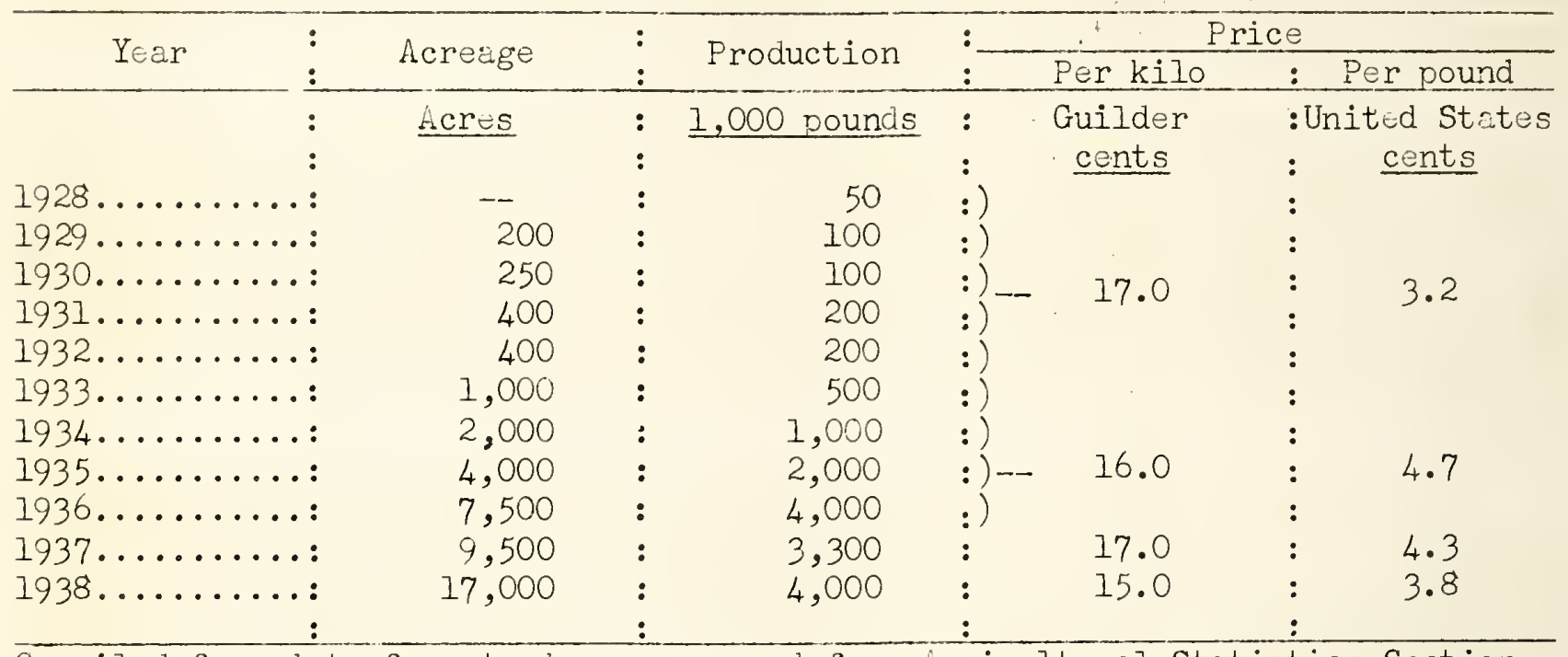

Cormiled from data from trade sources and from Agricultural Stetistics Section of the Central Bureau of Statistics of the Netherlands Indies. a) Largely air-cured; only about 250,000 pounds of the $1937 \mathrm{crop}$ and about 800,000 pounds of the 1938 crop were flue-cured.

In 1928 less than 100 acres of American-type flue-cured leaf were grom in the Bodjonegoro district. This was largely a trial plenting, but commercial production began the folloving yecr. Expansion was relatively slow until 1933. By that year the acreage had increased to only about 1,000 acres. Since 1933, higher prices for American flue-cured lewf, combined with a large incruase in Netherlands Indies leaf import duty (from 3.27 to 8.05 United States cents per pound) and Government regulations thet required the use in machine-rnede ciEsrettes of a fixed percentage of domastic loef, has resulted in a sharp increase in acreage. In 1934 about 2,000 acres were planted and by 1938 acreage had been increased to about 17,000 acres.

Yields per acre are substantially below the average in the United States and until 1937 averaged around 500 pounds. Yields in 1937 and 1938 were low as a result of very adverse westher conditions and averaged only about 350 and 235 pounds per acre, resnectively. Production as a result of the upwerd trend in acreage increased from about 500,000 pounds in 1933 to cpproximately 4,000,000 pounds in 1938.

Bodjonegoro leaf from American flue-cured seed is somewhat similar in appearance to the fmericen type 1la. It has about the same color and thickness of leaf but is somewhet inferior in texture. It has a fair amount of oil, burns well, has a high sugar content, and a moderately good aroma. 
during recent years heve averaged near 900,000 pnunds annually. It is sold there primarily for use in pipe mixtures. Madura Kerf tobacco is used in domestic cigarettes, cigares, strootjes, and chewing tobacco.

Soils in the viadura district are predominately calcareous clays derived from shales and limestones. Average annual rainfall in the district is about 67.2 inches per year, but the summer and early fall montha are very dry. Wionthly average rainfall in August and September is 0.5 inch or less. As in most of Java, the months December through Warch are rainy. Rainfall is heaviest in January, the average for the month being 12.1 inches.

Tobacco production in the district is entirely in the hands of natives, and is continuous throughout most of the year. Planting extends from liarch through July and harvesting from June through November. Cultivation and curing practices vary. The process of curing and handling that portion of the crop purchased for export or for sale locally to cjgarette nanufacturers is somewhat similar to that applied to Krossok in the Java districts. The treatment accorded most of the remainder is similar to that arplied to Sumatra Kerf.

\section{GRADING AND MARKETING}

Practices followed in the grading and marketing of tobacco in the Netherlands Indies probably vary more than those of any other country. Methods vary from those followed by tho aborigines to the detailed and unique system followed in handling the estate production of Sumatra and Java. Grading varies from no grading at all in the case of much of the native tobacco to the systematic methods of estate companies, which enable leaf of different grade from individual estates to be sold in the Netherlands on the basis of samples. Narket practices vary from barter between natives to sales on the Amsterdam and Rotterdam inscriptions.

\section{Grading}

Kerf Tobacco

The form in which Kerf tobacco is prepared for market largely precludes grading. In the most important producing districts the leaves are sometimes sorted prior to cutting, roughly in accordance with their position on the plant. This is not general, however, and well over half of the production is prepared in shredded form without any previous grading. Then shredded it can be graded only in accordance with color, freeness from insect damae, and general cleanliness. There are no recognized standards of the product, and tobacco from several producers growing the same type of leaf will vary in accordance with methods followed in preparation.

$\underline{\text { Krossok }}$

Krossok is in eneral carefully graded by the estate companies and middlemen, who ferment and pack it for market. Grade standards vary as between different handlers as well as between different types of leaf; however, fundamental practices by which grades are determined are relatively uniform. Variations in standards for a particular type of tobacco result largely from the 
degree of precision followed, which is often determined by the use for which it is intended. Some Krossok destined for use in domestic cigars and cigarettes may be roughly sorted into only a few grades determined by color and the position of the leaf on the plant. On the other hand, trie grades of cigar types of Krossok grown by natives under the supervision of estate companies may be nunerous. In this case careful consideration is given to thickness of the leaf, texture and color.

The factors taken into consideration in grading krossok as well as estate leaf are as follows: (1) position on the plant: top, middle, and bottom; (2) thickness of leaf: usually two qualities, thick and thin; (3) texture; fine, medium, and coarse; and (4) color, (the number of color classes varies with types from only two in the case of certain cigarette and pipe-tobacco types to five or more for some cigar types).

The grading of Krossok is begun prior to fermentation. The hands of leaves are sorted largely in accordance with color, and off-colored leaves in individual hands are removed. Further sorting is made after fernentation. If carefully done, the hands are broken and each leaf examined in accordance with the above characteristics 1 to 4 , the leaves of different grades being retied into hands. Less-careful grading consists in a reexamining of the hands and their being sorted into grades for which the requirements fit most of the leaves in the hand. Leaves. that are strikingly off-grade are removed from the hand.

After fermeritation and grading have been completed, the tobacco is packed in bales of approximately 220 pounds that are wrapped with straw matting. The bale is labeled with the name of the company that packed it, the type of leaf contained, and the grade designation.

Estate Leaf

The grading of estate tobacco begins in the field. Tobacco from fields which, because of their soil properties, are known to produce a particular type of leaf, is brought together for fermentation and grading. Priming and curing of the crop are so regulated that sorting in accordance with the position of the leaf on the plant is made as the leaves go into curing barns.

Each leaf is examined prior to stringing, and injured leaves are segregated and cured separately. When cured they are tied in hands containing leaves of relatively uniform quality, and after fermentation the hands are broken and each leaf is again examined separately and classified in accordance with thickness of leaf, texture, and color (see figure 9). This work is done by carefully trained graders, who work under the constant superijsion of foremen, who, in turn, have had many years' experience in grading. In the case of the better cigar types, each of the three main grades determined by position on the plant is subdivided into as many as 15 or more subgrades.

When grading is completed, the leaves are again tied in hands and carefully packed in bales of about 182 pounds in the case of Sumatra and Vorstenlanden leaf, and approximately 220 pounds in the cese of other estate tobacco. The bales are wrapped in a special type of straw matting. Labels on each bale show the estate company which grew the leaf, the estate on which it was grown, and the exact grade. 
Figure 9. - Grading of Sumatra wrapper leaf after it has been fermented.
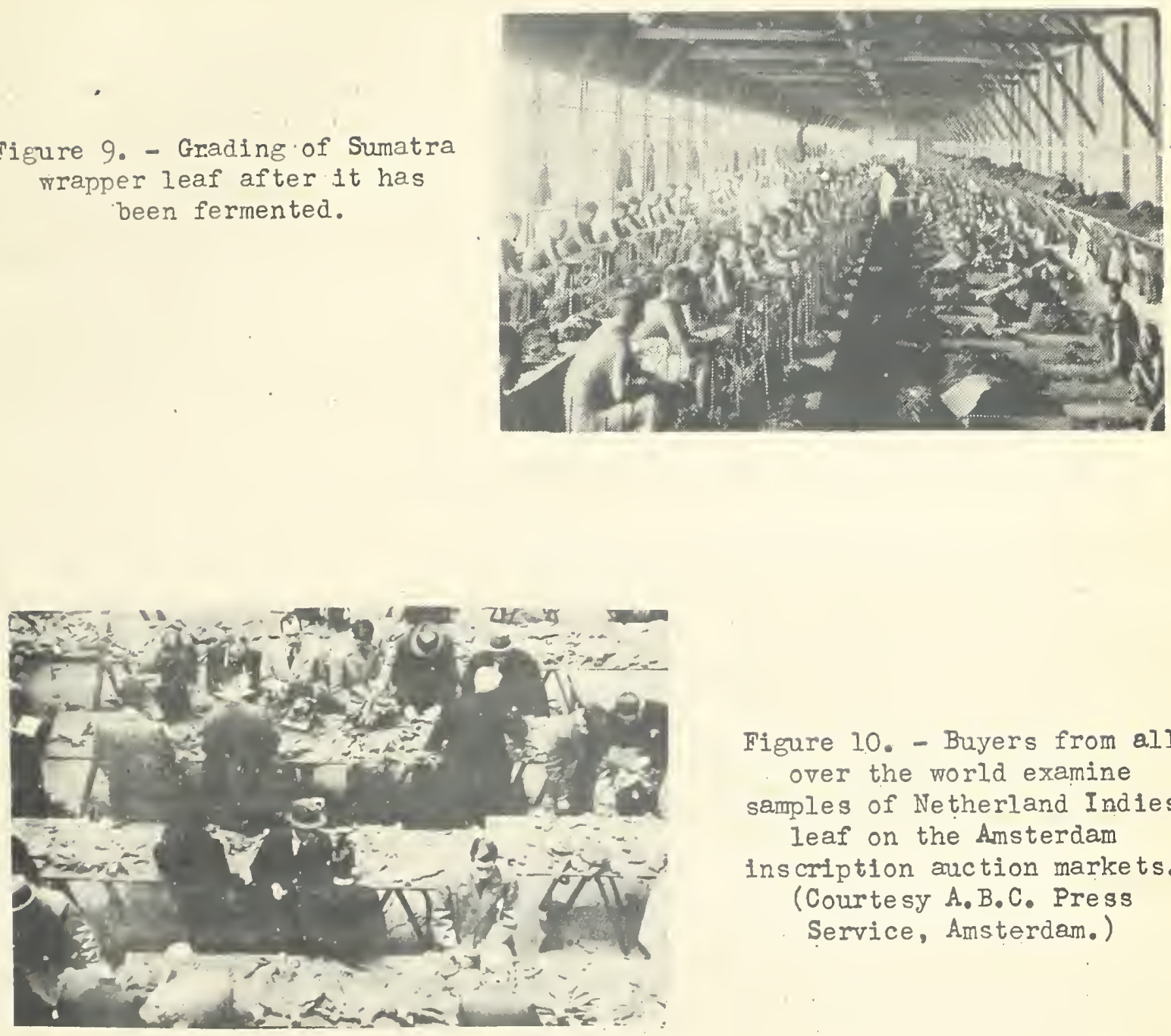

Figure 10. - Buyers from a.l over the world examine samples of Netherland Indies leaf on the Amsterdam inscription auction markets. (Courtesy A.B.C. Press Service, Amsterdam.)

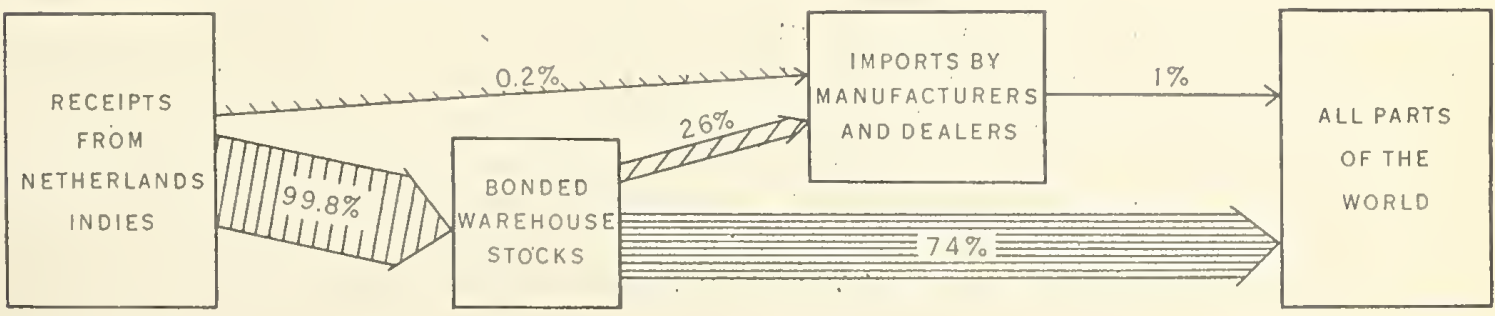


Java Flue-cured

Leaf from American flue-cured seed grown in Java is graded somevhat in accordance with American standards. As yet the portion of the crop that is actually flue-cured is largely limited to lugs and leaf grades. After fluecuring, these two main grades are each sorted into four subgrades primarily in accordance with color and soundness of leaf. Most of the crop that is air-and sun-cured is sorted into six grades, primarily in accordance with color, size, and soundness of leaf.

Grading of the portion of the crop that is flue-cured is done entirely by buying agencies. Most of the crop that is air-and sun-cured is also graded by the buying agency. Grading by native farmers is very limited.

\section{Werketing}

\section{Kerf I'obacco}

Native Kerf tobacco that enters commercial channels is sold by farmers to small Chinese or native dealers, who in turn resell it to larger dealers, to the manufacturers of strootjes, cigirettes, and cigars, or to exporters. There are no est: blished markets, and purchases by dealers from producers are usually made at the farm or the buyer's warehouse. The portion of production not sold to dealers moves direct from producers to consumers. It is frequently sold at village markets along with vegetables and other prociuce and in some cases is bartered to natives in exchange for other native products.

\section{Krossok}

Practically all of the Krossok is purchased by relatively large dealers or estate companies who ferment and grade it. Resales of such leaf for dornestic consumption are made to manufacturers of cigarettes, cheap cigars and shag. Shipments to the Netherlands account for practically all of the exports of such leaf. It is received there by brokers that represent the Netherlands Indies firms and is sold on the Amsterdam and Rotterdam auctions.

\section{Estate Leaf}

Most of the estate companies ship their entire production of leaf to the Netherlands soon after it is fermented and packed. This practice was started when the production of estate leaf began, and markets in the Netherlands have continued to be the only place where such leaf can be purchased in volume. One reason for the practice is the unsatisfactory storage conditions in the Netherlands Indi s. Leaf held there is subject to damage from high humidity combined with high temperature, and from weevil. Such damages are negligible in the temperate climete of the Netherlands. A further reason for sales in the Netherlands is that practicelly the entire production is purchased by European buyers and the le: $f$ is brought to them rather than requiring them to go to the Netherlands Indies. 


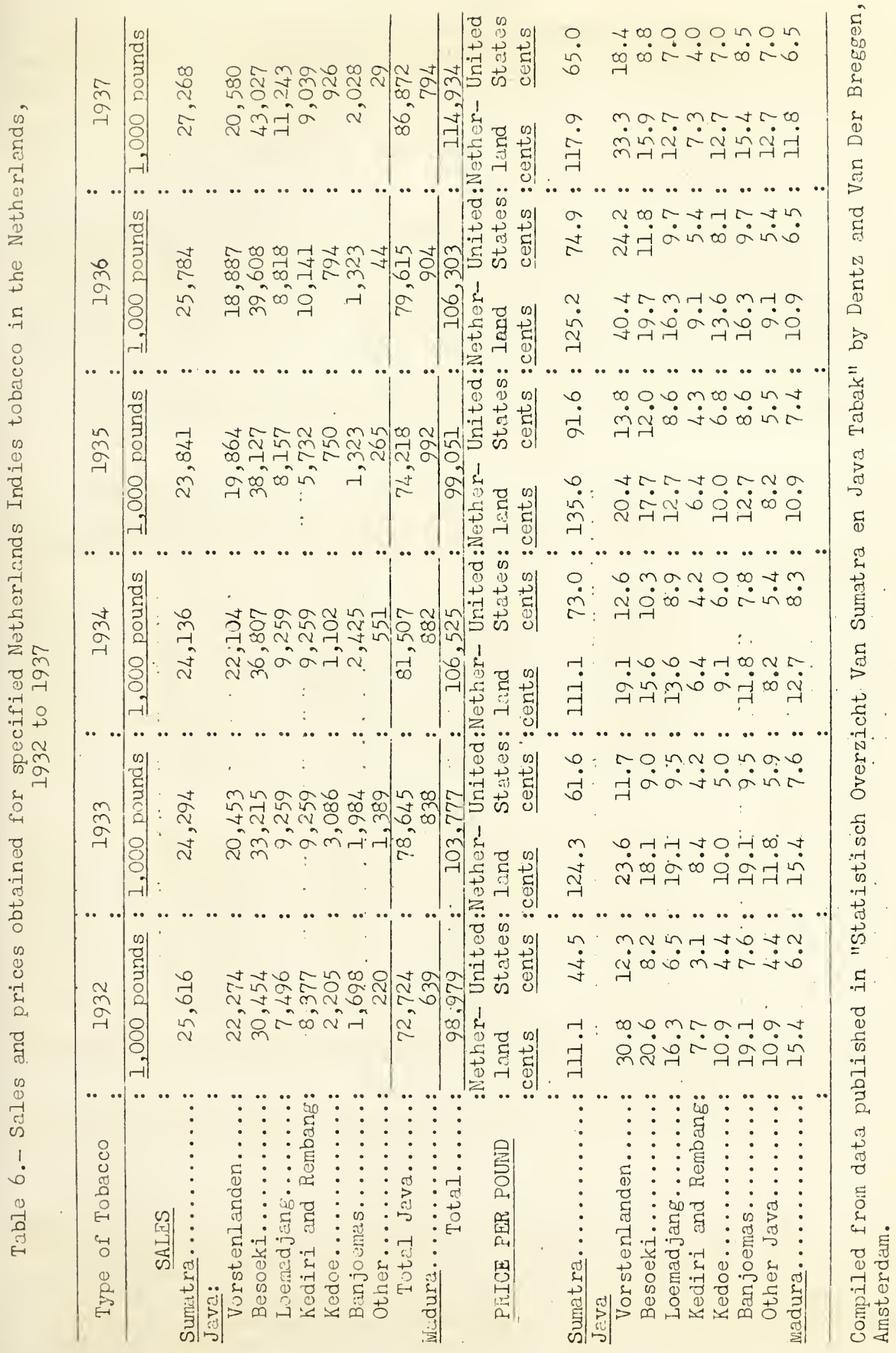


Great care is taken in loading the estate leaf in boats for shipment to the wetherlands. ' It is put only in well-ventilated holds and the bales are never ricked to a height of more than six bales. This prevents dariage from overheating and also prevents leaves in the bottom bales from being broken by excessive weight. As a further protection against breakage of leaves, the bales are always ricked directly on top of each other rather than allowing them to overlap, which is the usual practice in loading cargo.

Shipments of estate leaf to the Netherlands are received by brokers who represent the different estate companies. They offer the leaf, on the basis of samples, on the Amsterdam and Rotterdam auctions, where it is purchased largely by cigar manufacturers and leaf dealers (see figure 10). Approximately 85 percent of Sumatra wrapper leaf and about 70 percent of Java and Wadura estate leaf is reexported from the Nietherlands (see figure 11).

Table 7.- Sales in the Netherlands of Sumatra, Java, and Miadura tobacco, quantities retined for domstic use and quintities reexportid, 1931 to 1938

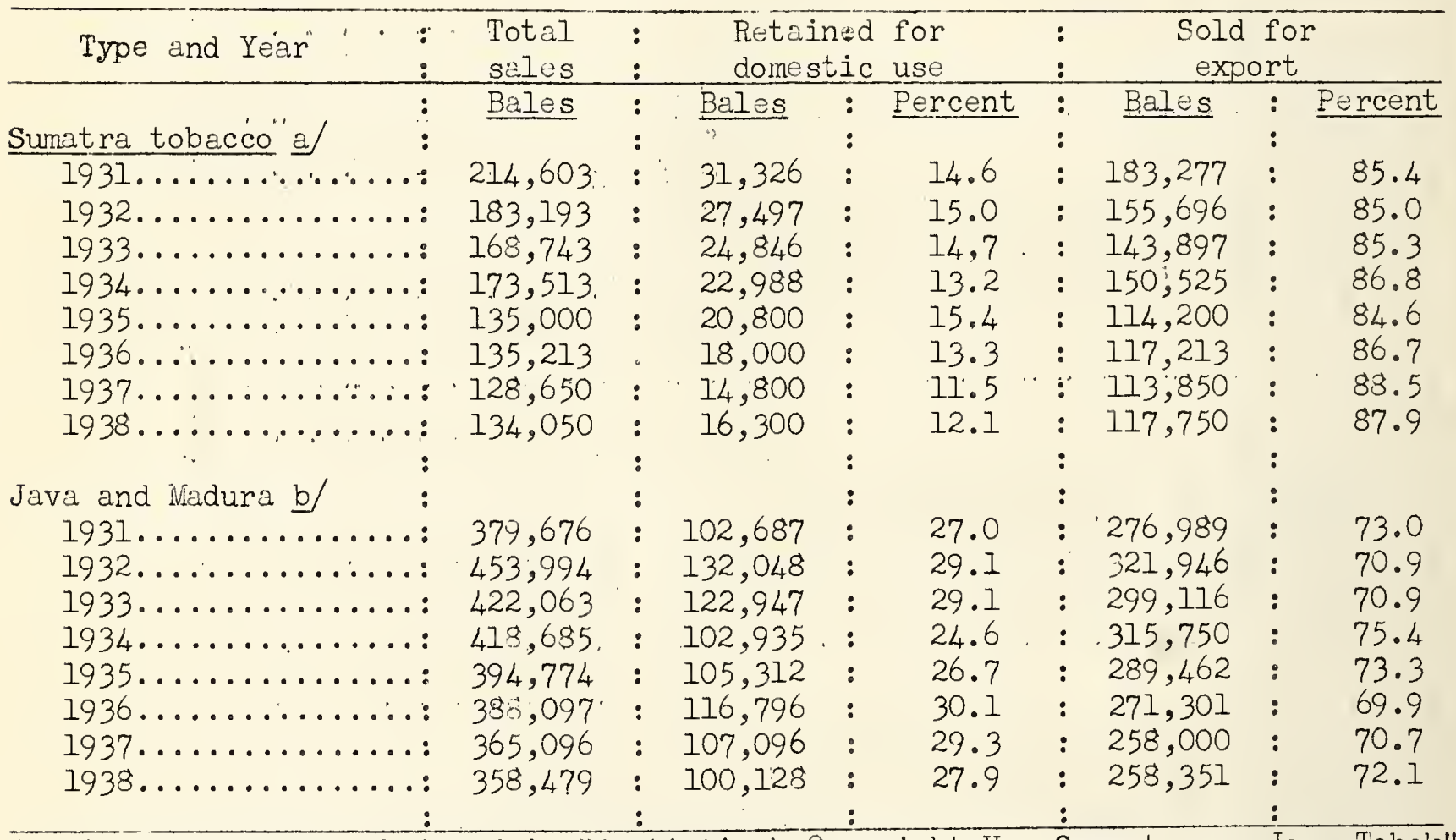

Compiled from data published in "Statistisch Overzicht Van Summatra en Java Tabak" by Dentz and Van Der Breggen, Amsterdam.

a) Beles averaging about 220 pounds.

b/ Partly of bales averaing about 220 pounds and othersaveraging about 182 pounds.

Java Flue-cured

Nost of the Java flue-cured leaf is purchased from farmers by the companies that have been instrumental in expanding its production. When seedlings are sold to natives by a company the grower obtains a bond or contract which guarantees that the company will purchase his leaf. Then the crop was first introduced, the bond or contract, given by the single company that was interested in the crop, specified prices at which the compiny would purchase leaf of particular grades. 
This guaranty is no longer carried in the customary contract. In practice the contract now merely serves to insure the native a market for his leaf. It also serves as an identification, which he must present in order that the issuing company may know that the leaf was from seedlings it sold to the native.

The usual contract does not require the grower to sell his leaf to the individual or agency from whom he secured seedlings, and prior to 1938 small concerns were purchasing increasing quantities of flue-cured leaf grown from seedlings furnished by the larger companies. This practice was objected to by the larger companies and as a result of their complaints the Netherlands Indies Government in 1938 issued an ordinance that stopped it and in effect binds the grower to sell his leaf to the individual or agency from which he obtained seedlings. The ordinance requires that all buyers of flue-cured leaf in the Bodjonegoro district have a government permit or buying license. Licenses are issued only to individuals or agencies who have fumished farmers with flue-cured seedlings, and the license specifies that the holder may purchase flue-cured leaf only frorn farmers to whom they furnished seedlings.

As yet prectically the entire supply of Jave flue-cured leaf has been used in the domestic manufacture of cigarettes. Exports have been limited to samples shipped to the Netherlands.

\section{IMPORTS AND EXPORTS OF LEAF TOBACCO AND. TOBACCO PRODUCTS}

The Netherlands Indies has for many years been second to the" United States as an exporter of leaf. tobacco. The exports have been approximately one-third of the volume sent abroad, from the United States and in most recent. years well above exports from Greece, the world's third largest exporting country. Leaf imports into the Netherlands Indies have always been small but at times have exceeded the imports of Japan and certain European countries. The islands' export trade in tobacco products has always been insignificant, but prior to sharp increased duties in 1932 and 1934, imports ô products were relatively large.

\section{Exports}

Since 1909 combined exports of leaf tobacco and tobacco products from the Netherlands Indies (with the exception of the last 2 World War years when shipment to Europe was difficult) have ranged between $99,000,000$ and 302,000,000 pounds annually. There have been only 3 years, however, when exports exceeded $200,000,000$ pounds. One of them was the year preceding the above-mentiored period when exports were low as a result of the war, and another was the second year following the war. Since 1925, the last year in which exports exceeded 200,000,000 pounds, the trend has been downward and for the 5 years 1934 to 1938 they averaged only about $106,000,000$ pounds annually. Leaf exports have always accounted for nearly 100 percent of total tobacco exports. Exports of tobacco products, largely cut tobacco, have seldom exceeded $3,000,000$ pounds annually and, during the 5 years ended with 1938, averaged about 703,000 pounds annually.

Approximately 90 percent of the leaf exported goes to the Netherlands where most of it is sold for reexport (nearly 80 percent during recent years). Most of the reinaining 10 percent is sent to other European countries. Shipment to the Straits Settlements and Egypt have at times been important but most of such leaf is apparently for reexport to Europe. Exports direct to the United States have been insignificant except during the last 2 witorld War years and the 3 years immediately following. 
Table 8.- Exports of leâf, Krossok, and Kerf tobacco, 1920 to 1938

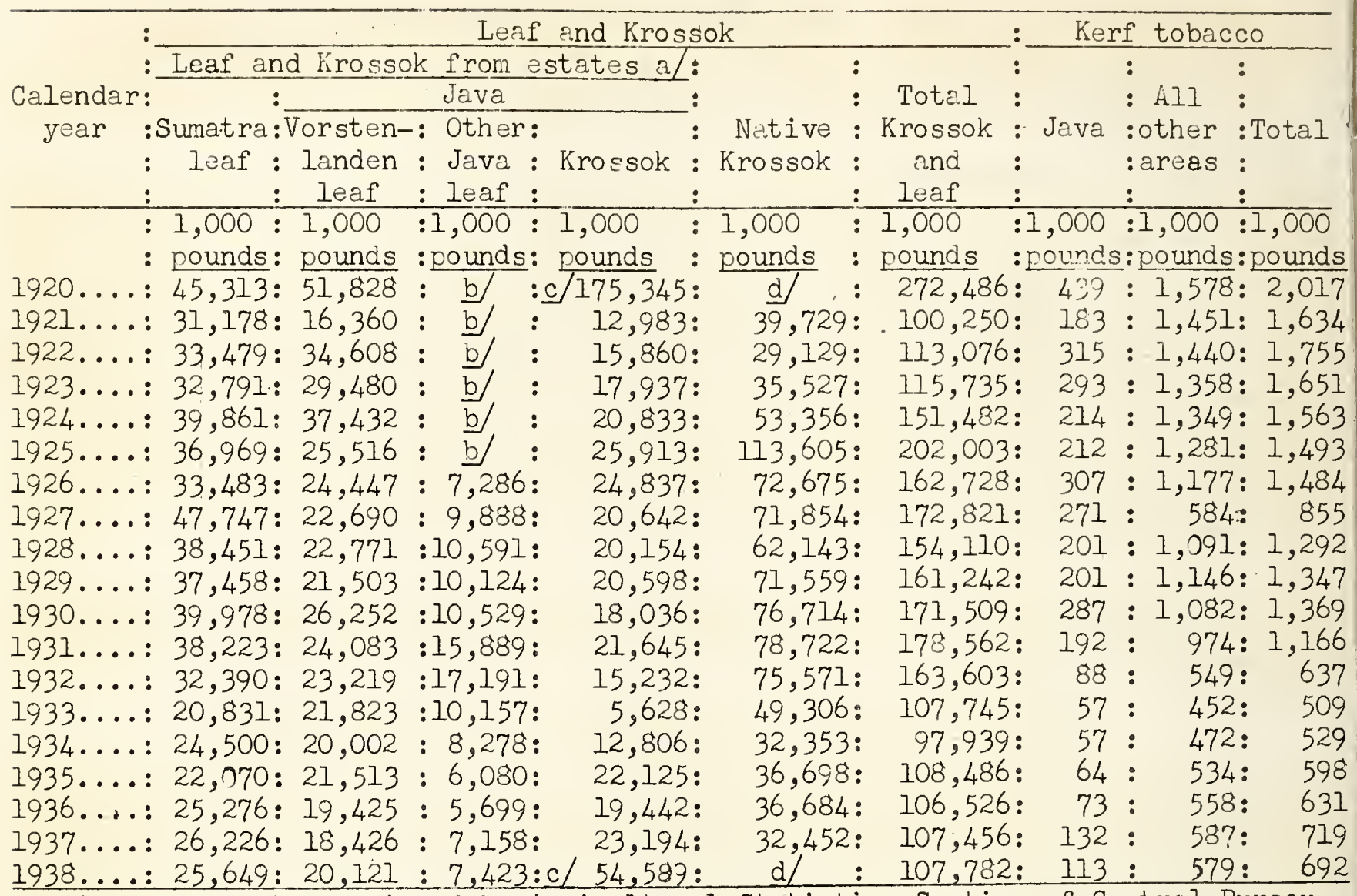

Compiled from data furnished by Agricultural Statistics Section of Central Bureau of Statistics of the Netherlands Indies.

a/ Includes tobacco purchased from natives and handled by estates. b/ Included with Vorstenlanden. c/ Includes native Krossok. d/ Included with estate Krossok.

Cigarette exports have seldom exceeded 100,000 pounds annually, and for more than half of the years since 1909 they have been less than 25,000 pounds. Exports to the Netherlands and the Straits Settlements have accounted for most of the total. Cigar exports have also been insignificant. There have been only 2 years since 1909 when the annual export exceeded 100,000 pounds. For half of the years in that period they were below 25,000 pounds annually.

Exports of cut tobacco (primarily Kerf) since 1909 has ranged between 508,000 and 3,595,000 pounds. The trend during the entire period has been decided$1 y$ downward and for the 5 years 1934 to 1938 such exports averaged approximately 630,000 pounds annually. Shipments have been almost entirely to the Straits Settlements, where the product is consumed by natives.

\section{Imports}

Combined imports of leaf tobacco and tobacco products since 1909 have ranged between 6,967,000 and 34,749,000 pounds annually. The trend was upward until 1929 but has been downward since that year. Combined imports for the 5 years ended with 1938 have averaged only about 10,200,000 pounds annually. The sharp decline in recent years has resulted primarily from high import duties and regulations requiring that machine-made cigarettes manufactured in the islands contain a high percentage of domestic leaf ( 60 percent during recent years). 
From 1909 to 1912, lesf imports ranged between 3,000,000 to 5,000,000 pounds annually, but declined sharply for the 10 years 1913 to 1922 when they averaged only 455,100 pounds annually. The decrease resulted from the demind for cigarettes being more nearly supplied by cigarette imports and from the importation of cut tobacco for use in the domestic manuf cture of cigarettes. From 1923 until 1929, leaf imports.increased substantially with the larger cigarette demand. Since 1929 they have declined sharply as a result of higher irnort duties and also during the past few years, because of regulations requiring the use of a higher percentage of domestic leaf in cigarettes manufcctured.

American flue-cured leaf has for many years comprised the bulk of leaf inports. Until 1925 most of such imports were by transhipments through the Straits Settlements, China, Hong Kong, and the Philippines. Beginning with 1926 direct imports from the United States have accounted for most of the total. Except for a few years when imports of Chinese flue-cured leaf were relatively large, leaf imports from sources other than the United States have been small.

Cigarette imports into the Netherlands Indies since 1909 have ranged between 185,000 pounds and 10,108,000 pounds annuelly. The trend was upward from 1909 to the peak year of 1923 but has been downward since that year. During the 5 years ended with 1938, imports averaged only 599,000 pounds annually. The sharp decline in the past 5 years can be largely attributed to higher import duties.

Imports of cigarettes from the United Kingdom and the British possessions of Egypt, Hong Kong, and the Straits Settlements account for most of the total. China has been a source of supply, but such imports heve been relatively insignificant except during the period 1921 to 1928. The Netherlands have never been an important source of supply; during recent years imports from this source have ranged between 1,000 and 6,000 pounds annually. Since 1909, there has been only 1 year when cigarette imports from the United States exceeded 150,000 pounds. From 1934 to 1938 the average annual import from this country was only about 37,000 pounds.

Cigar imports have seldon exceeded 1,000,000 pounds annually and for the 5 years ended with 1938 averaged only 98,000 pounds annually. The Netherlends have been the primary source of supply, but substantial quantities from other countries have been imported through the Straits Settlements. Imports direct from the Philippinss, though small, exceed those from any direct source other than the Netherlands. Imports direct from the United States have been practically nil.

For most of the yeirs since 1909, imports of tobacco products other than cigars and cigarettes have exceeded the combined imports of leaf, cigarettes, and cigars. They have ranged between $3,200,000$ and $11,000,000$ pounds and there has been no pronounced trend. A substantial part of the import is tobacco, primarily An $\Rightarrow$ rican flue-cured, cut ready for use in the manufacture of cigarettes. This practice is rollowed as ? rusult of the humid climete of the Natherland Indies. Leaf held in storage or even handled in the islands loses its color, and cigarette manufacturers have edopted the practice of importing cut leaf in moisture-proof paper bags. It is used in cigrettes immediately or within a few weeks after its arrivel.

The United Kingdom and the Netherlands have been the primary source of cut tobacco imports. Imports from China und Hongkiong, which are largely Chinese pipe tobacco for use by the Chinese population, are next in importance to imports from the Netherlands and the United Kingdom. Imports direct from the United States have seldom exceeded 40,000 pounds ennually and for the 5 years 1934 to 1938 they averaged only 11,000 pounds. Until recent years imports from the United Kingdom were largely transhipped from the Straits Settlements and were therefore reported from 


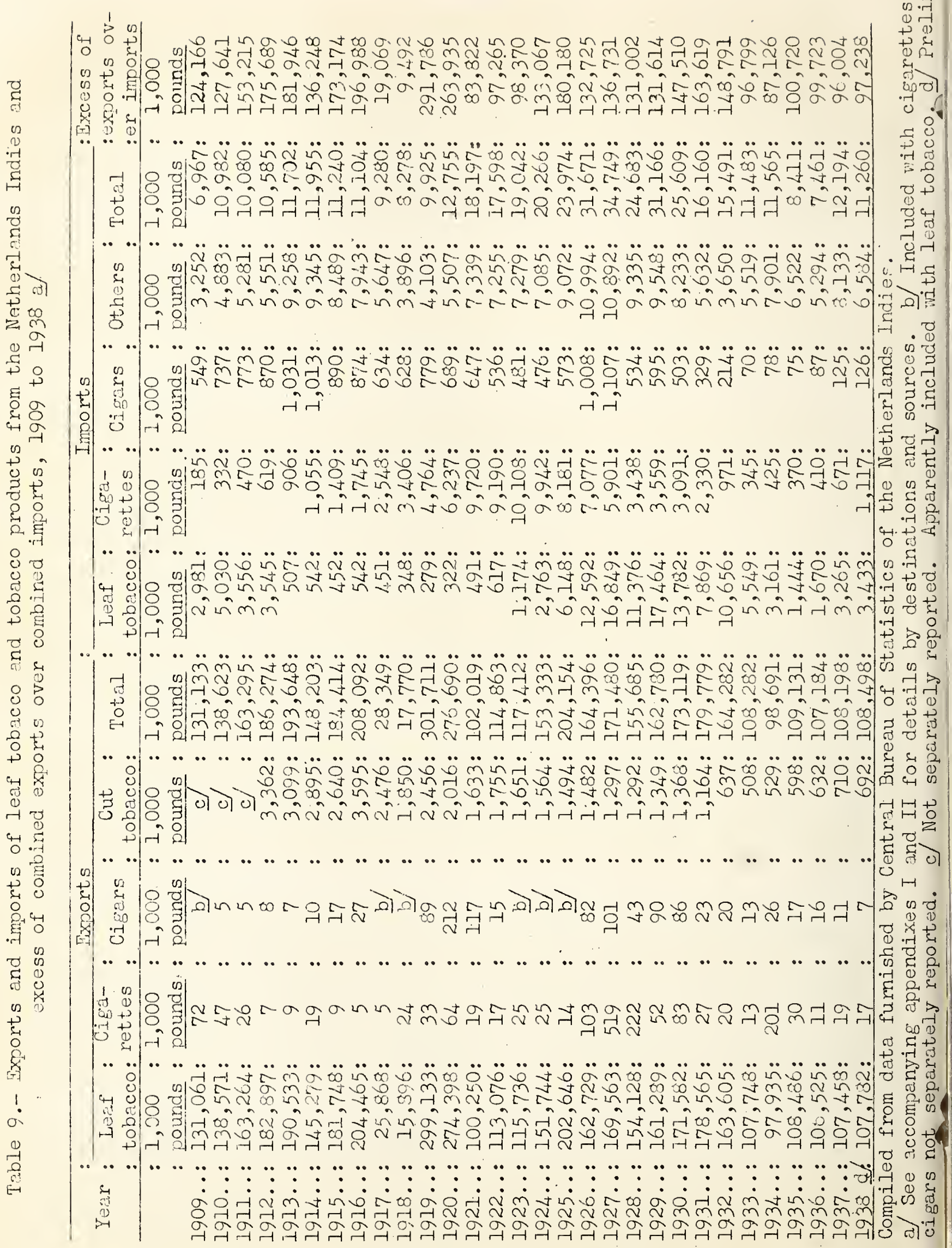




\section{Import and Export Duties}

Duties on leaf tobacco and tobacco products imported into the Netherlands Indies have never been as high as those of many countries; however, duty increases in recent years have tended to restrict imports to minimum requirements of special-quality leaf and high-grade tobacco products.

Import duties on leaf tobacco and tobacco products other than cigarettes and cigars were first imposed in 1866. The rate including surtax was low, 8 guilders per 100 kilograms (about 2 cents per pound at the 1938 exchenge). This was not changed until 1924, but beginning with that year there has been a series of increases. The last increase was in January 1934, when the rate including surtax for cut tobacco, processed stems and snuff, was raised to 27 guilders per 100 kilograms (about 8.05 cents per pound at the 1938 exchange). The duty including surtax on leaf was left at 18 guilders per 100 kilograms (about 4.5 cents per pound at the 1935 exchange).

Import duties on cigarettes and cigars were first made in 1886 . They were not changed until 1921, but were increased progressively from then until 1932 , when the rate, including surtax, was made 225 guildere per 100 kilograms (about 56 cents per pound at the 1938 exchange). The last change was on February 1 , 1936, when the rate was lowered to 150 guilders per 100 kilograms (about 37 cents per pound at the 1938 exchenge). The decrease was made as a result of an increase in internal tax from 20 to 30 percent of vilue.

The following tabulation gives import duties including surtaxes on leaf tobacco and tobacco products and dates they became effective.

Efiective Date

Leaf tobicco and products other

than cigars and cigarettes

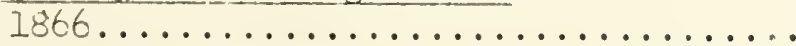

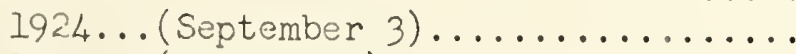

$1931 . .($ January 1)

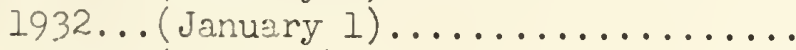

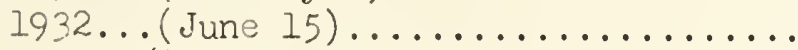

$1934 \mathrm{~b} /($ January 10).
Natherland guilders per 100 kilos
United States centsper pound $3 /$

\section{Cigars and cigarettes}

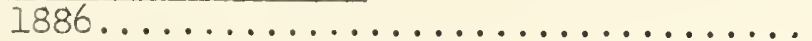

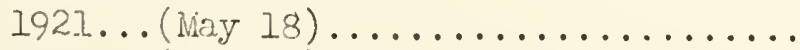

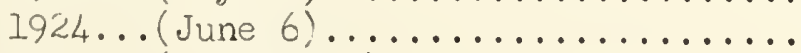

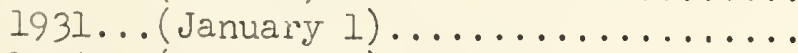

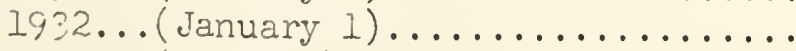

1932...( June 15).

1936...(February
8.00

12.00

13.20

14.40

18.00

27.00
2.04

2.39

2.61

3.27

8.02

Compiled from data furnished by the Treasury Office of the Netherlands Indies. a/ Converted to Unitid States cents per pound at prevailing rate during year in which duties became effective. b/ Rate applies only to cut tobacco, processed stems, snuff, and other tobacco products cxcepting cigars and cigarettes. Leaf, unprocassed stems, and strips were left unchanged at 18 guilders per 100 kilograins. 
An export duty on leaf and cert in tobacco products has been in existence in the Netherlands Indies since 1866. The orienal duty, which has not been changed, applies only to leaf tobacco and cut tobacco other than Kerf, all other products, including Kerf, have been free of the duty. The rate has been low, only 1.00 guilder per 100 kilograins ( 0.2 cent per pound at the 1938 exchange) and was originaily made for fiscal reasons. At the time it was imposed the Netherlands Administration in the islands had difficulty in levying direct internal taxes, and resorted to export and import duties to meet the cost if government. In more recent years internal taxes have become possible and the export duty has been rernoved on certain types of leaf during periods when prices for the leaf have been low or at times when they have been subject to direct internal taxes.

Java and Sumatra estate tobacco and Hrossok handled by estate companies from the crons of 1919 to 1922 was exempt from the export duty as a result of the leaf being subject to an internal tax during the period.

In January 1935, as a result of low prices, the export ciuty was removed for all tobacco originating in Java and Jadura; however, the regulations provided that they might be renewed on July 1, 1938. Prior to this date, the duty exemption on all Java and liadura lesf excert Vorstenlanden leaf was extended until July 1, 1939, and has subsequently been extended until July 1, 1940.

In addition to the tobacco export duty, there has been, since February 24 , 1938, a national defense export duty equivalent to 1 percent ad valorem on prectically all goods leaving the islands. Exemption from the duty is extended to certain agricultural procicts and other raw materials only during periods of unusually low prices. The applic tion of this duty to leaf tobacco other than Sumetra wrapper leaf and Vorstenlinden leef was renoved on February 12, 1939.

\section{WANUFACTURE AIND CONSUMPTION OF TOBACCO FRODUCTS}

Consumption of tobacco in the ivetherlends indies during the 5 years 1934 to 1938 averaged approximaty 146,000,000 pounds (processing order I/) annually. of this anount, spproximetely $135,000,000$ pounds were supplied from domstic tobacco, about $6,500,000$ pounas from the import of leaf and cut tobacco primarily for use in cigarettes, and 3,500,000 rounds from imports of tobacco products other than cut tobacco.

The percentige of total consumption represented by different products during the 5 jours, 1934 to 1938, was approximately as follows:

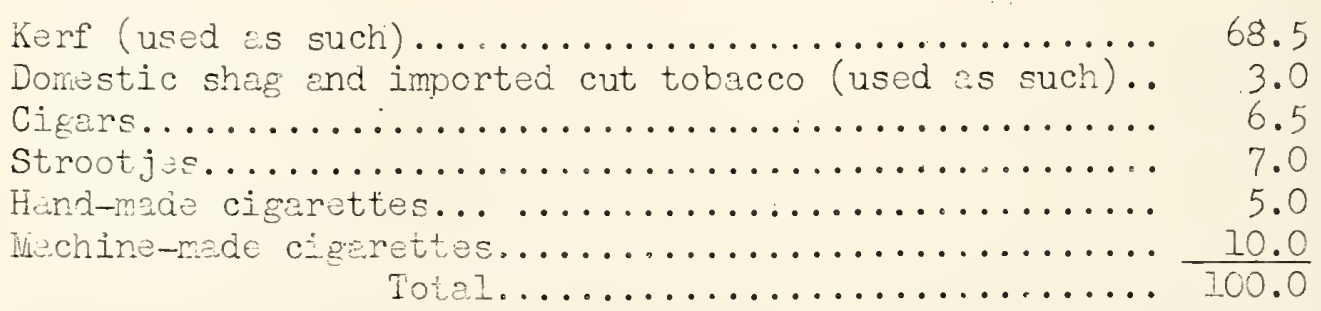

Snuff is also used in smell quentities, but its percentage in terms of total tobacco used is of no significence.

I Condition of the tobacco at the time it is used in manufacture. 


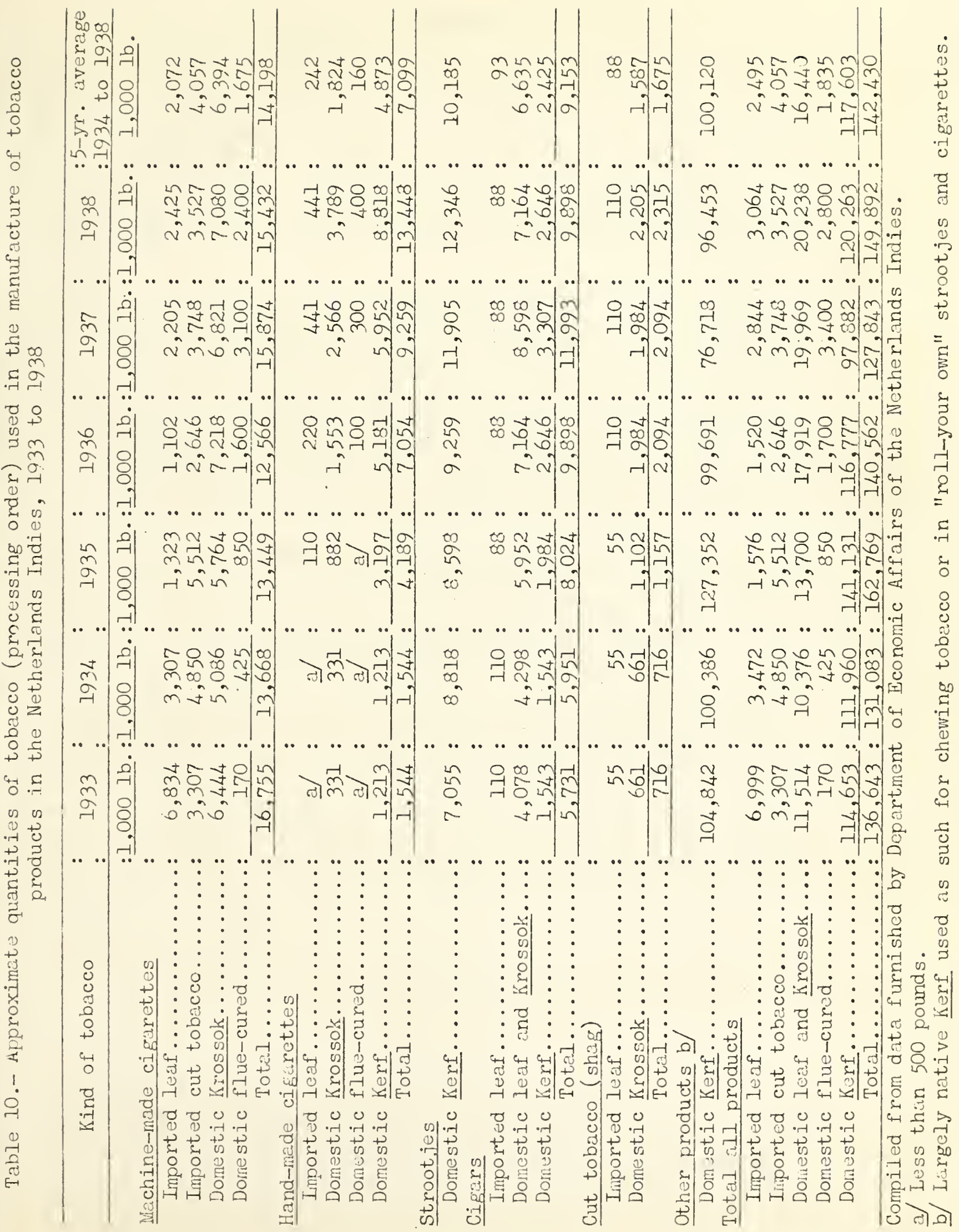


Kerf

The consumption of Kerf, used directly as such, in recent years is approximated at about 100,000,000. pounds annually. As has been previously explained, it is prepared by natives during the curing process and is ready for consumption immediately after curing or after aging. All types of native leaf are converted into herf, but there is seldom any blending or mixing of different types. Consumption in a particular locality is usually confined to Kerf prepared from leaf grown in the section; however, the west coast of Sumatra, middle and east Java, Midura, Celebes, Bali, and Sombok are surplus producing districts, from which shipments are made throughout the islands.

Salés to consumers are made largely through native markets and shops where the tobacco is sold along with vegetables and other native products. There are but few stendard packages or brands. It is usually retailed unpackaged in quantities ranging from a few ounces to severel pounds. Except for small portions of the better quality sold by recognized commercial houses in stendard containers and under trade names, it is not taxed and prices to consumers are usually low. They are highest in nonproducing districts where distribution from surplus areas is mide through. Chinese; and native dealers. In surplus and self-sufficient areas where the product moves direct from producer to retailer or consumer, prices to consumers are not greatly in excess of leaf prices.

The product is used in roll-your-own cigarettes, and as chewing tobacco. In the former case, which is most extensive, com huske or tree leaves are commonly substituted for cigarette paper.

\section{Domestic Shag and Imported Cut Tobacco}

During the 5 years, 1934 to 1938, consumption of domestic shag and imported cut tobacco amounted to approximately 4,500,000 pounds annually. this amount, about 1,700,000 pounds were représented by domestic shag and $2,800,000$ pounds by imports of brands of cut tobacco commonly sold in Europe.

The imported product, as a result of the relatively high import duty and an internal tax, which was 20 percent of retail value until February 1, 1936, and 30 percent after that date; sells at relatively high prices. It is only used by Europeans and the well-to-äo natives in roll-your-own cigarettes and for pipe smoking.

Domestic shag is subject to the internal tax but, as it is produced by domestic manufacturers and largely from domestic leaf, it sells for materially lower prices. It is used almost entirely in roll-your own cigarettes.

\section{$\underline{\text { Cigars }}$}

The manufacture and consumption of cigars in the Netherlands Indies is small despite the fact that the islands rank among the important cigar-leaftobacco producing countries. This is due to the fact that most of the cigar type leaf grown is high in price and quality.

linst of the cigurs sold in the islands are of domestic origin and are made from tobacco that is below export quality. More than half of the production is 
from low-grade Krossok used as filler and similir quality or low-grade estate leaf used as binder and wrapper. In the other portion of production kerf is used as filler, paper of the brom cigarette type as binder, and a low grade estate leaf or Krossok as wrapper. The domestic products are chiefly small sized cigars that sell in competition with cheap cigarettes snd strootjes. During recent years approximately 9,000,000 pounds annually of domestic leaf and Kerf have been used in the local manufacture of cigars.

Consumption of imported cigars, which are used largely by the European population, amounted to only about 98,000 pounds annually during the 5 years, 1934 to 1938.

The native cigars are all hand-made. There are a few relatively large est.blishments and many small concerns thet menufacture for sale through wholesale or retail establishments. In addition there ar a number of individual cigar makers who sell their output direct to retailers or consuners.

Since 1933, all cigers sold in the country have been subject to an excise tax equivalent to 20 percent of the retail value, Retail prices for donestic products, however, are extremely low. In 1938 over two-thirds of total sales (both domestic and imported cigars) sold for less than 5 cents per package of 4 or more cigars, and over half sold for about 0.5 cent or less per package. (see table 11).

\section{Strootjes}

Strootjes are a domestic product made from native Kerf rolled in corn husks. Niany of the brands also contain a mixture of sugar, cloves, and certain other spices. Tobacco used in their production for retail sales during the 5 years 1934 to 1938 averaged approximately 10,000,000 pounds annually.

The commercial production of strootjes is entirely by hand but most of them are made in relatively large Chinese and native establishments that employ makers on a piece basis. The product has about the same length as a cigarette but is somewhat cune-shaped, rather than cylindrical and does not contain as much tobaccu as the average cigarette. Wost of them are packed for retail sale in paper packs cuntaining 4 to 10 pieces. When cormercially produced they are subject to an excise tax of 20 percent of retail value and sell at an average of about $\$ 1$. IO per thousand pieces. Distrioution is through wholesalers, who handle them along with cigarettes and other products sold to small retail shops, or by retail direct by producer to consumer.

\section{Cigarettes}

Leaf Used

Tubacco used in ciserettes consumed in the Netherlands Indies during recent years exceeds the use in all other products except Kerf. Prior to import duty incresses in 1932, imported cigarettes represented a substantial part of total consumption (approximately 20 percent for the 10 years 1923 to 1932) but during the 5 years 1934 to 1938 domestically mede cigarettes accounted for most of the total. During this period, leaf used in donestic production averaged about $21,000,000$ pounds annually, wherecs cigarette imports average less than 600,000 pounds annually. 
For the 5 years ending with 1938 ; the annual quantity of leaf used in domestic manufacture of cigarettes was approximately as follows:

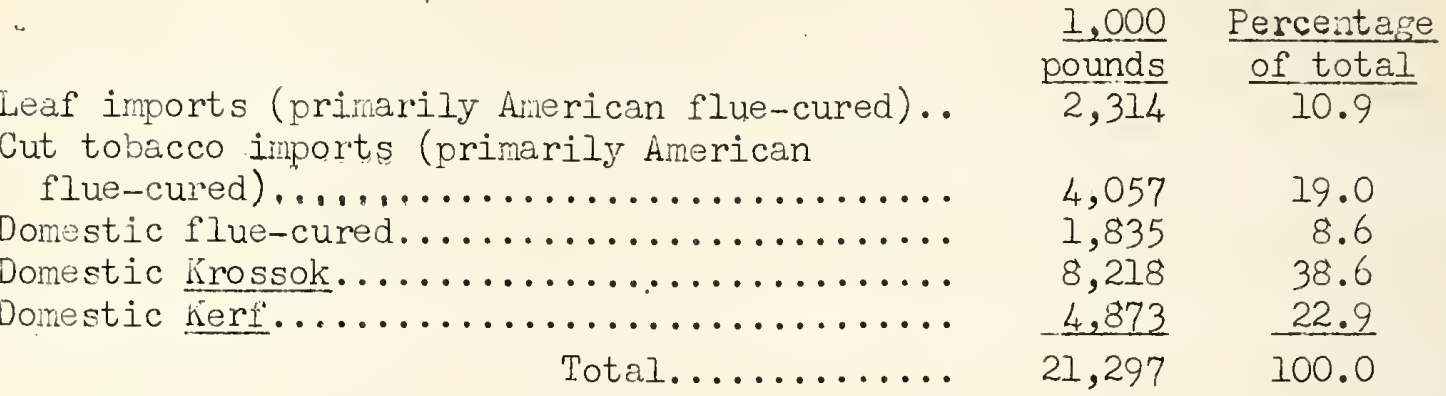

Increases in domestic flue-cured leaf production during recent years, combined ith Government regulations recuiring machine-cigarette manufacturers to use a high percentage of domestic tobacco in cigarettes have resulted in decreased utilization of imported leaf and cut tobacco. The decrease, however, has been more than offset by an increase in use of donestic flue-cured, Krossok, and Kerf.

Total tobacco used in domestically made cigarettes increased from approximately 18,300,000 pounds in 1933 to 28,900,000 pounds in 1938, but during this period the use of imported leaf and cut tobacco declined from about 10,100,000 to $6,300,000$ pounds annually. On the other hand, utilization of domestic fluecured ircreased from about 170,000 to 2,800,000 pounds; domestic Krossok from 6,800,000 to 10,900,000; and domestic Kerf from 1,200,000 to 8,800,000 pounds annually.

Nachine and Hend-rolled Production

Cigarette manufacture in the Netherlands Indies is carried on by both machine manufacturers and hand-roll operators. During the 5 years 1934 to 1938 machjne manufacturers produced about 67 percent of total production and handrollers 33 percent. Hand-rolled production, which can be accomplished with less cost than machine menufacture has, however, geined on machine production. In 1933 hind-roll operctors used only about 1,500,000 pounds of leaf ( 8.3 percent of totel) as contrasted with approximately 16,700,000 pounds ( 91.7 percent of tot:l) used by the machine manufacturers, whereas by 1938 leaf used by hand-roll operators had increased to approxinately 13,400,000 pounds (46.5 percent of total as coripared with $15,400,000$ pounds ( 53.5 percent of total) used by machine manufiacturers.

The making of hand-rolled cigarettes began on a conmercial scale about 30 Jears ago. In 1939 there vere between 300 and 400 relatively large concerns engaged in this industry. In eddition, there were several thousand independent individual makers or units employing only a few makers. Most of the larger concerns employed less then 100 operators but a few have over 2,000 persons engeiged solely in rollin cigarettes. The cigerettes are rolled in small handoperated contrivances that make a single cigarette at a time. The average operator can roll approximtely 2,000 cigerettes per day. At this rate, the daily output of sone of the larger companias is over 4,000,000 pieces. 
These larger concerns have cutting machines and other equipment needed for making the tobacco ready for the cigarette. Some of them also have cigarette-making machines and are classified as both machine manufacturers and handroll producers. Part of the small units ind indidividual makers have their leaf cut by a larger concerm, but in most cases they use native herf that does not require processing.

The hand-roll operators cater exclusively to the low-priced-cigarette trade, and leaf used by them is largely domestic Krossok and Kerf. Cloves and other spices are also extensively used in this product. Machine manufacturers use large quantities of domestic Krossok but no Kerf. During the 5 years ended with 1938, their utilization of domestic Krossok represented about 45 percent of total utilization. The remaining 55 percent was largely imported or domestic grown flue-cured leaf.

\section{Government Supervision of Machine Cign rette Manufacturing Companies}

During recent years there heve been about 14 or more machine-cigarette manufacturing companies operating in the Netherlands Indies, all having their factories in Java. Of this number, 4 produce almost the entire output of machine-made cigarettes and it is estimated that the largest of the 4 (British American Tobacco Company) produces over 75 percent of the total. The large number of companies in operation has resulted in what local authorities consider undue competition. In order to maintain their position, the older and larger, better-financed organizations have in the past undersold the smaller and in many cases newly established concerms. With a view to remedying this situation, the Governor General of the islands on September 1, 1935, extended by decree the "Industrial Regulation Ordinance of 1934" to include the machinecigarette manufacturing industry. I/ This decree empowered the Director of Economic Affairs of the islands to prescribe and carry out regulations designed to limit competition and to stabilize the cigarette industry. Regulations prescribed by the Director becarne effective on September 1, 1935, and since that date machine manufacturing companies have been under Covernment supervision.

The regulations assure each machine-cigarette manufacturing company a definite maximum sale of cigarettes during each quarter of the calendar year. The assurance is provided through the control of cigarette-tax stamps. Inmediately preceding each quarter of the year the Director of Economic Affairs, after consultation with a committee representing the industry, fixes the expected consumption of cigarettes, expressed in terms of retail value, for the coming quarter. The forecast is based on current conditions, the value of cigarettes consumed during the previous quarter, and during the corresponding quarters of previous years. The total quota forecast for the quarter is prorated amone the different manufacturers in accordance with their share, in terms of value, of total cigarettes sold prior to september I, 1935.

The tax stamps show the retail price of the packages to which they are to be affixed, and vary in denominations from 1 to a 100 or more guilder cents.

I] The ordinance of 1934 empowered the Governor General to impose regulations necessary for the stabilization of industry in the Netherlands Indies. Translation of decree pursuant to the ordinance that relates to the machine-cigarette manufacturing industry is attached hereto, Appendix III. 
Each manufacturer is permitted to purchase stamps to cover his total allotment of sales in any combination of denomintions he desires. Separate series showing different serial numbers are printed for each manufacturer and the stamps cannot be transferred from one manufacturer to another. Furthermore, unused stamps of a particular quarter cannot be used in subsequent quarters.

When the system was first put into force the regulations provided that a reissue of stamps within a quarter could be made only when most of the manufacturers exhausted their original allotment before the close of the quarter. The reissue in such cases was prorated among all manufacturers on the basis of the original iscue for the quarter. This proved somewhat unsatisfactory as individual companies frequently exhausted their allotment before the end of the quarter and, when other companies were not in the same position, they were unable to secure stamps and could not supply the demand for their products. The frequency of such happenings resulted in the regulations being modified in October 1938 so that reissues of stamps could be made to individual companies even though competing companies had not exhausted their original supply.

In addition to the control of machine manufacturers through the quota system, the Director of Economic Affairs also has the authority to regulate minimum retail prices for different-sized cigurettes. After consultation with a committee representing the industry in 1935, the director fixed minimum retail prices for machine-made cijgrettes having different cubic contents of tobacco. These prices are, however, subject to change with chenges in the industry and consumer demend.

\section{Tax Rates}

The tax rate is the same on hand-made and machine-made cigarettes, and is collected trirough the sale of tax stamps. The charge for stamps of all denominations is a fixed percentage of the value appearing on the stamp, i.e., the retail price of the package to which the stamp is to ba attached. When internal revenue taxes on tobacco products were put into effect (December 1932), the rate charged on cigarettes and all other products was 20 percent of retail value. On February 1, 1936, the rate on cigarettes and cut tobacco packed in the "European" manner (unpacked native Kerf not included) was increased to 30 percent of retail value, but that on other taxable products was left unchanged.

\section{Distribution end Retail Prices}

Some of the larger machine-cigarette-manufacturing firms maintain their own distributing organizations, which provide for the delivery of cigarettes from factories to retailers. They maint in depots in different localities, and representatives traveling from them make sales direct to retailers or to wholesalers that handle cigarettes along with other products. Wost of the small machine-cigarette-munuficturing firms and the larger hand-roli concerns sell their output to wholesile houses that hindle cigarettes along with other products. The small hand-roll establishments and individual hand operators sell their production direct to retailers or consurners.

The per-capita consumption of cigarettes in the islands is relatively low. In 1938 it was about 230 pieces per capita per year, which is comparable with consumption in China, much below that in Japan, and far below the per-capita 
consumption in Europear countries and in the United States. Per-capita consumption is highest in Sumatra and certain islands where wages and incomes are higher than for the densely populated islands of Java and Madura. Total consumption, however, is greatest in Java and vadura. The following tabulation shows estimated consumption in 1937 and 1938 by principal areas as determined from total production and shipments from Java:

Shipped to:

1937

$\frac{\frac{1,000 \text { pounds }}{\text { of tobacco in }}}{\text { cigarettes }}$

Sumatra............

Barneo..............

Celebes..............

Other islands...

$$
\begin{array}{r}
8,053 \\
1,995 \\
2,484 \\
578
\end{array}
$$

12,023

25,133

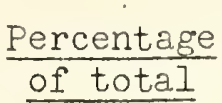
of total $\underline{1938}$ $\frac{1,000 \text { pounds }}{\frac{\text { of tobacco in }}{\text { cigarettes }}} \frac{\text { Percentage }}{\text { of total }}$ 8,480
1,850
2,316
611 $29 \cdot 4$ 6.4 8.0 2.1

$$
\begin{array}{r}
32.1 \\
7.9 \\
9.9 \\
2.3
\end{array}
$$

$$
\frac{47.8}{100.0}
$$

$\frac{15,623}{23,880}$ $\frac{54.1}{100.0}$

There are about 300 or nore brands of cigarettes sold. The price range is wide but the average price for total sales is low. Tax returns in 1938 show that approxinately 45 percent of total sales were retailed at prices below 1.5 cents per package. The cheaper hand-made products sell as low as \$1.10 per thousand and average about \$1.20 per thousand. Wost of the machine-made product sells between $\$ 1.40$ and $\$ 2.20$ per thousand. It is estimated that sales at prices above \$2.20 per thousand account for less than 5 percent of total cigarettes sold.

Tablo 1l.- Percontage of silas of asch tobacco product, in terms of value, by price groups, and percentage each product of all products, 1933-1938

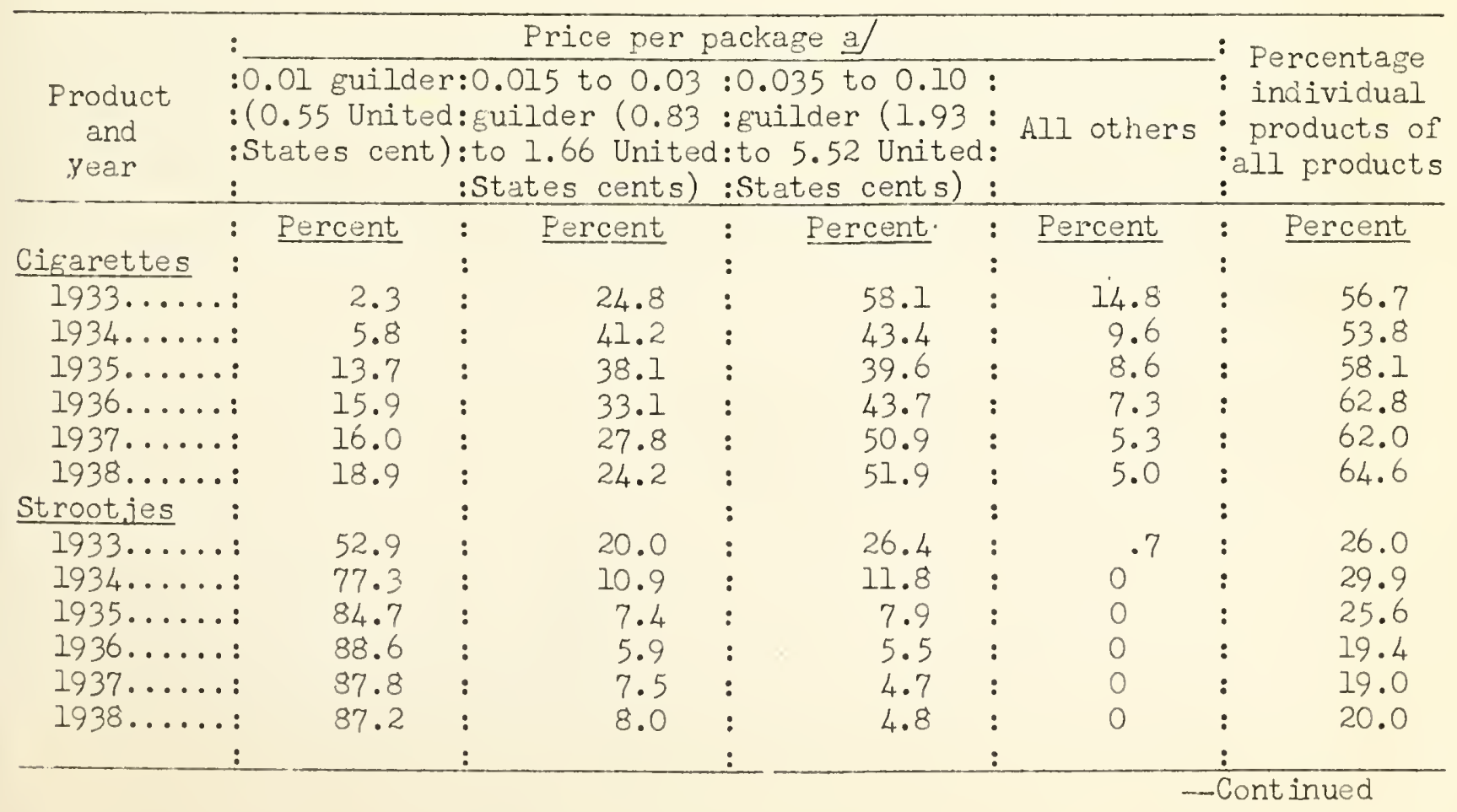


Table 11.- Percentage of sales of each tobacco product, in terms of value, by pric groups, and percentage each product of 211 products, 1933-1938 - Continued

\begin{tabular}{|c|c|c|c|c|c|c|c|c|c|c|}
\hline \multirow[t]{2}{*}{$\begin{array}{l}\text { Product } \\
\text { and } \\
\text { year }\end{array}$} & \multicolumn{9}{|c|}{$\begin{array}{l}\text { Price per package a/ } \\
: 0.01 \text { guilder:0.015 to } 0.03: 0.035 \text { to } 0.10: \\
:(0.55 \text { United:guilder }(0.83: \text { guilder ( } 1.93: \text { All others } \\
: \text { States cent): to } 1.66 \text { United:to } 5.52 \text { United: } \\
: \quad: \text { States cents }): \text { States cents }):\end{array}$} & $\begin{array}{l}\text { Percentage } \\
: \text { individual } \\
\text { : products of } \\
\text { :Il products }\end{array}$ \\
\hline & $:$ & Percent & $:$ & Percent & $:$ & Percent & $:$ & Percent & $:$ & Percent \\
\hline Cigars & : & & : & & : & & : & & : & \\
\hline $1933 \ldots \ldots$ & & 22.9 & $:$ & 11.3 & : & 12.8 & : & 53.0 & : & 7.8 \\
\hline $1934 \ldots \ldots$ & & 39.6 & : & 10.9 & : & 13.6 & : & 35.9 & : & 8.5 \\
\hline $1935 \ldots \ldots$ & & 46.3 & : & 7.2 & : & 10.2 & : & 36.3 & & 8.0 \\
\hline $1936 \ldots \ldots$ & & 50.0 & : & 4.9 & : & 7.3 & : & 37.8 & & 5.8 \\
\hline $1937 \ldots \ldots$ & & 51.7 & : & 4.4 & : & $7 \cdot 3$ & : & 36.6 & : & 5.0 \\
\hline $1938 \ldots \ldots$ & & 46.6 & : & 4.4 & : & 7.2 & $:$ & 41.8 & : & 4.9 \\
\hline Cut tobacco & & & : & & : & & : & & & \\
\hline $1933 \ldots \ldots$ & & 0.6 & : & 2.8 & : & 16.2 & : & 80.4 & & $9 \cdot 5$ \\
\hline $1934 \ldots \ldots$ & & 0.7 & : & $3 \cdot 3$ & : & 24.7 & : & 71.3 & & 7.8 \\
\hline $1935 \ldots \ldots$ & & 0.3 & : & 9.3 & : & 21.2 & : & 69.2 & & 8.3 \\
\hline $1936 \ldots \ldots$ & & 1.1 & : & 14.9 & $:$ & 25.4 & : & 58.6 & & 12.0 \\
\hline $1937 \ldots \ldots$ & & 0.2 & : & 3.0 & : & 23.5 & : & 73.3 & & 14.0 \\
\hline $1938 \ldots \ldots$ & & 0.1 & : & 4.8 & : & 28.9 & : & 66.2 & & 10.5 \\
\hline Al1 products & & & : & & : & & : & & : & \\
\hline $1933 \ldots \ldots$ & & 16.9 & : & 20.4 & : & 42.3 & : & $20 \cdot 4$ & & 100.0 \\
\hline $1934 \ldots \ldots$ & & 29.7 & : & 26.6 & : & 29.9 & : & 13.8 & & 100.0 \\
\hline $1935 \ldots \ldots$ & & 33.3 & : & 25.4 & $:$ & 27.6 & : & 13.7 & & 100.0 \\
\hline $1936 \ldots \ldots$ & & 30.1 & : & 24.0 & $:$ & 32.0 & $:$ & 13.9 & & 100.0 \\
\hline $1937 \ldots \ldots$ & & 29.2 & $:$ & $19 \cdot 3$ & : & 36.1 & : & $15 \cdot 4$ & & 100.0 \\
\hline & & 31.9 & : & 18.0 & $:$ & $37 \cdot 9$ & : & 12.2 & : & 100.0 \\
\hline
\end{tabular}

Conpiled from data published by the Bureau of Economic Affeirs of the Netherlands Indies Government in "Economisch Weekblad," Batavia, Java.

a/ Size of packages for the different products is not uniform, and part of the shift from the higher-priced to the lower-priced groups results from a reduction in the size of packeges. There are no seles at prices between 0.01 and 0.015 nor 0.03 and 0.035 guilder. United States values appearing in the hesding have been converted at 55.2 United States cents per guilder, the prevailing rate in 1937 and 1938 . 


\section{PROBABLE DEVELOFNENTS AFFECTING ANERICAN TOBACCO FARMERS}

It is expected that developments in the tobacco industry in the Netherlands Indies during the next several years will be somewhat unfavorable to American tobacco furmers; however, it is believed that they will not materially alter the present position of the United States in the world tobacco trade. Conditions that restrict the import of Anerican tobacco into the islands are expected to continue and American producers may soon lose most of that market. There will be some further shift in leaf production in Java to the American-type flue-cured; although the product will be of low quality and can compete on foreign markets only with the lower grades of tumerican flue-cured.

Tobacco production by the estate compunies, which includes Surnatra wrapper leaf and the better Java cigar types, vill probably be continued on a level that will enable the islands to fumish about the same portion of world export supply of cigar tobacco that they have in recent years. The policy of the agencies that control the output of these types will likely continue to be that of producing high-grade leaf in quantities that will yield maximum financial returns. There is no indication that they vill attempt to expand their export through materially reduced prices. Lower prices could be obtained only by inaugurating changes in production and handing methods that rould lover the quality of the leaf. Such action vould jeopardize the position that the leaf, as a result of its excellent quality, now unjoys on world markets.

The trund in production of dark and sumi-light air-cured types, which compete on European markets with certain hmericun dork and light air-cured types is doubtful. There will probibly be no direct effort, however, to regulate the supply of thase types with a view to mintaining prices. American growers, therefore, may expect that their competitjon with them will continue about as it has in the past several years or will increase.

There is evidence that the production of Americen-type flue-cured in Java will increcse shrply and that a substantinl portion of the production will be available for export to Europe. It is probable that developrents similar to those that have takun place in the Bodjongoro district will occur in other areas that have been found suited to production of the type. The flue-curad acreage planted in 1938 in the Bodjonegoro district, where production begun in 1928, was 17,000 acres. Uncier nomll conditions, this acre:tge would have produced a crop of about $8,000,000$ pounds. This amount would have been more than sufficient to replace the quantity of imported American flue-cured used in pipe mixtures and in medium- and low-priced cigarettes. In soite of the unfavorable weather conditions and resulting low yields experienced in the district in 1937 and 1938, it is expected that the acreige will continue to increase. With normal yields on increased acreage an export surplus would be immediately available.

Samples of American-type flue-cu ed le:s of recent Bodjone?oro crops sent to the Netherlands have been reported by Europeen interests to be of a quality sufficiently high for use in cigarettes. Jiva flue-cured type, however, probably will never be of sufficient quality to be used as a substitute for average- or above-average-quality Americon flue-cured in either domestic consumption or on European markets. Basic factors such as soil and climate will prevent its becoming equal in quality to the amerjecn product. It is also probable that 
production methods will continue such as to give low quality. Experinental trials by present estate companies have indicated that production costs and returns from growing the best quility flue-cured leaf obtainable would give smiller net returns than they can secure from types they now grow. It is not expected, therefore, that the present companies or similar organizations will undertake extensive production of the crop. Without the supervision of such organizations, quelity will remain below thet which might otherwise be obtained.

Flue-cured type tobacco produced in the Netherlands Indies will, for some time at least, be lareely shade- or sun-cured. Flue-curing in the Bodjonegoro district is as yet liriited to a relatively smill portion of the production cured by locel cigarette compenies and dealers that are primerily interested in the crop. It is doubtful if flue-curing con be successfully carried on by natives. It would at best require some yeurs before they could become proficient in the practice.

Dornestic consumption of cierettes and other commercial tobacco products in the islands is expected to increase boderately. Any pronounced increase would probably be met by higher taxes, which would check the rate of expansion. The trend to increased utilization of domestic tobacco, especially the fluecured type, in the production of domestic products is expected to continue. The relatively high duties that have been in effect since 1934 favor this trend. It is also probable that the Governinent will require still further utilization of domestic tobacco.

Imports of tobacco of American origin, largerly medium- to low-grade fluecured, will be further replaced with domestic flue-cured. Our outlet in the islands will perheps soon be limited to quintities needed in the production of better-grade cigarettes. Total ruquirents for this jurpose will be limited, as the present outlook indicates thit the portion of population with sufficient incone to use better quality cigarettes vill romain sinall.

Imports into the islands of tobacco products wich ure made largely from American leaf, will probebly continue at about the low level of recent years or may decline. Present duties on products f:vors domestic production, and there is no indication of a duty reduction. Exports of tobacco products are expected to remain at the low level of recent yairs. 


\section{APPENDIX I}

Imports of Leaf Tobacco and Tobacco Products by Sources. 1909 to 1938 


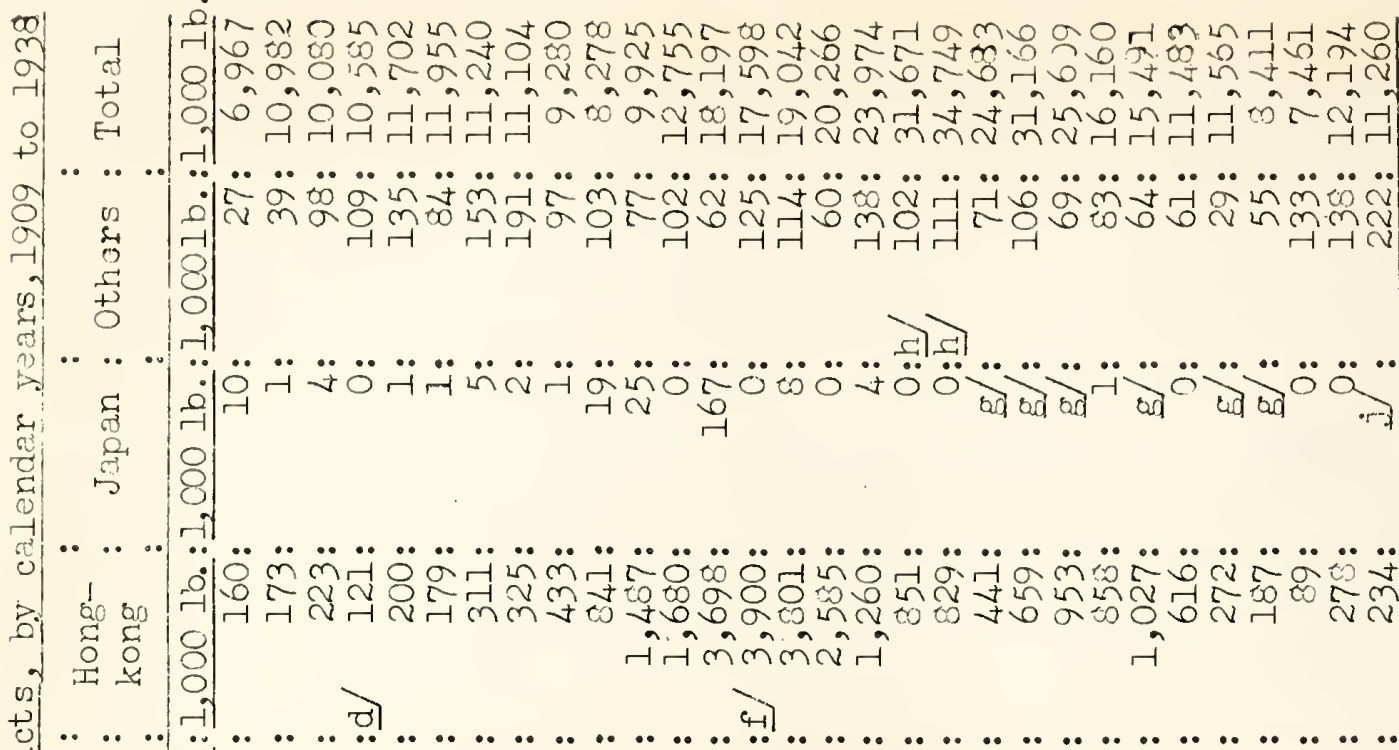

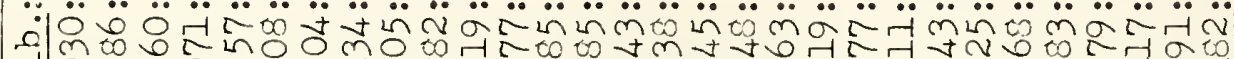

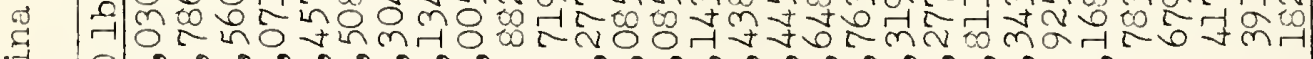

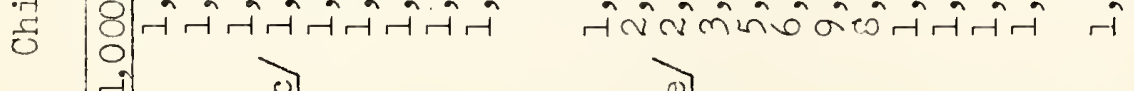

•. . क . 运 ... ..

on 1 ]

का.

o

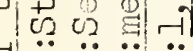

年

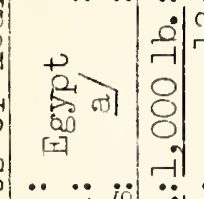

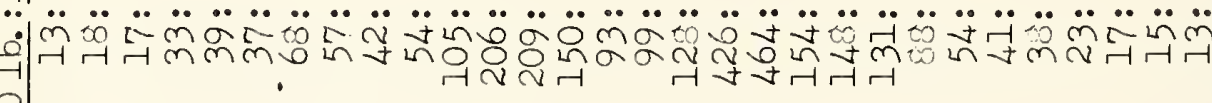

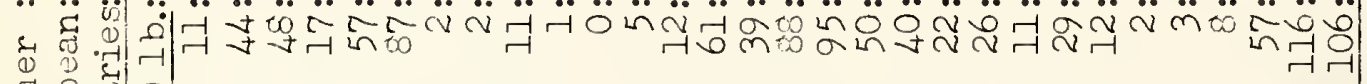

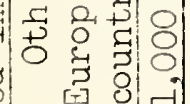

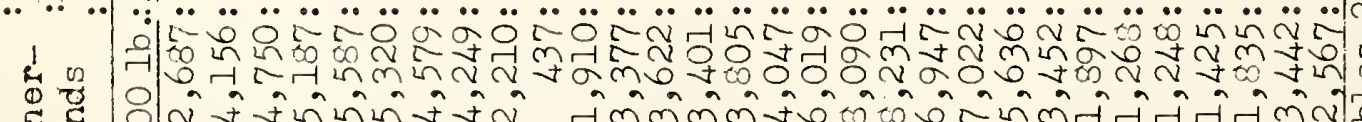

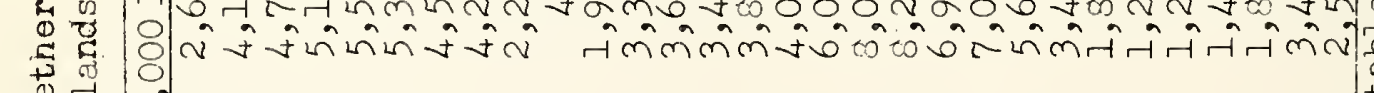

द्व.

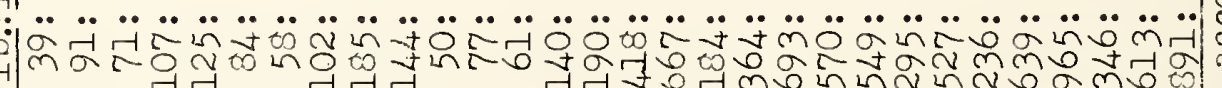

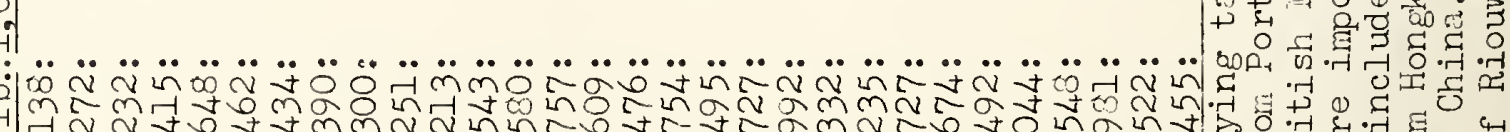




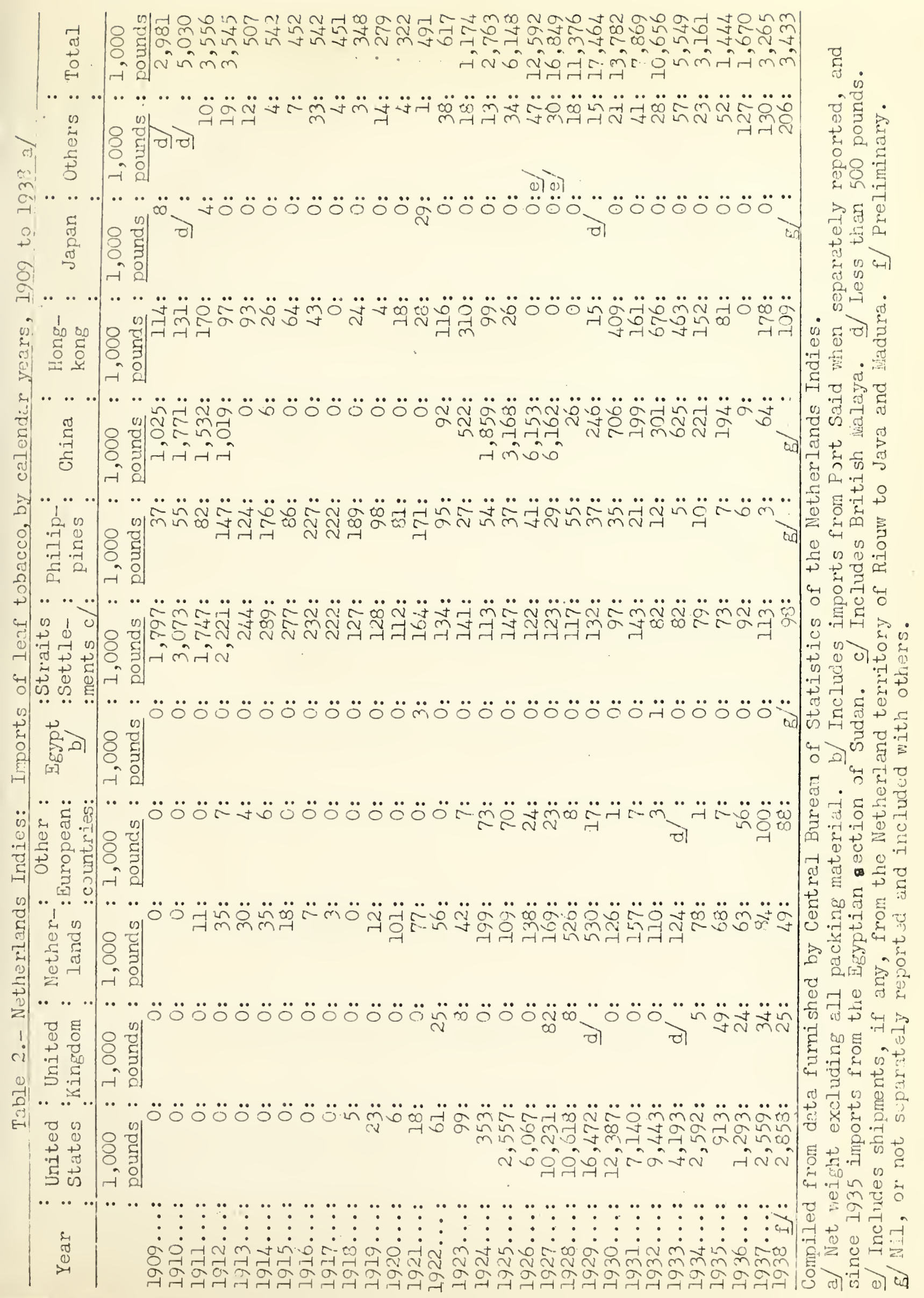




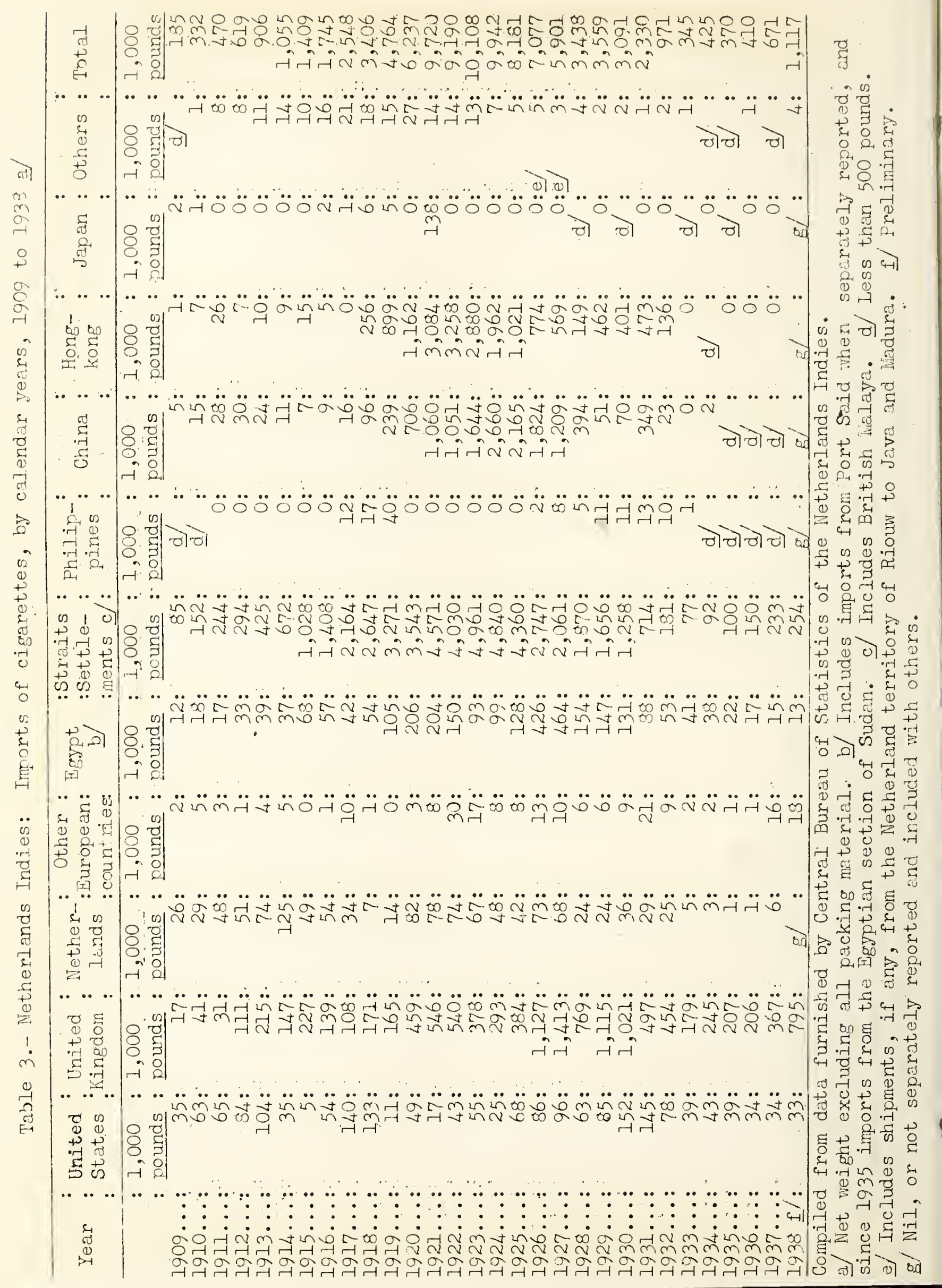




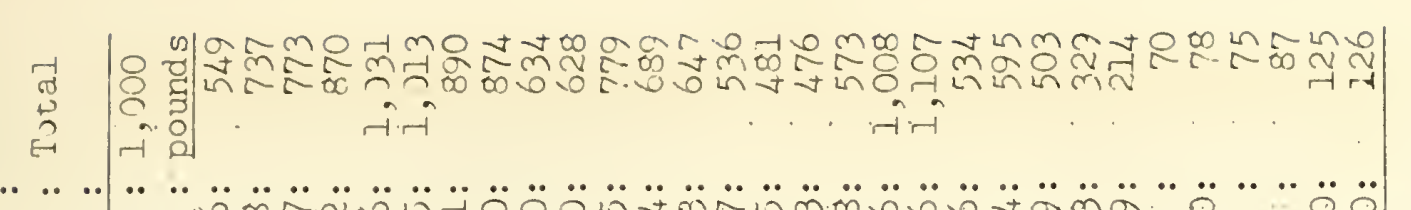

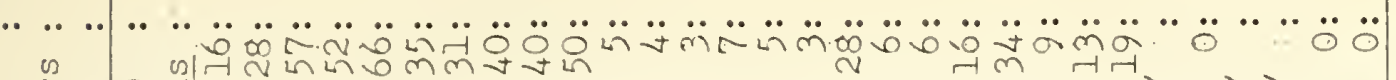
8 己્વ

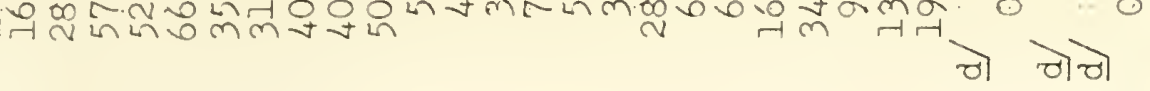
मे

\section{and ald}

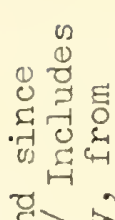

䗆

वें iें

+ ठ

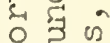

당

(4) $\Omega$

름

p을

()

तु

\& $\backsim$

की is ए ज ? (1) थ $0 \begin{gathered}0 \\ 0\end{gathered}$

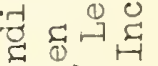
द्ञ

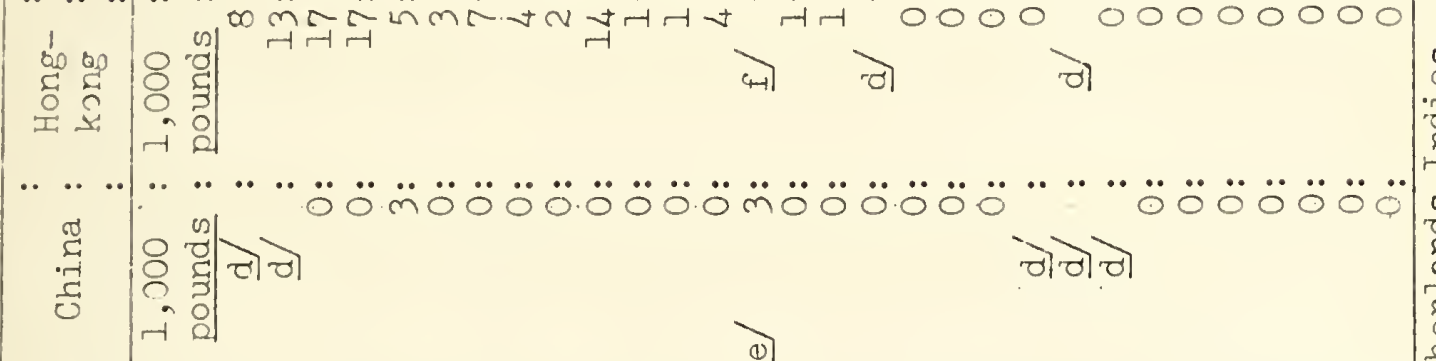

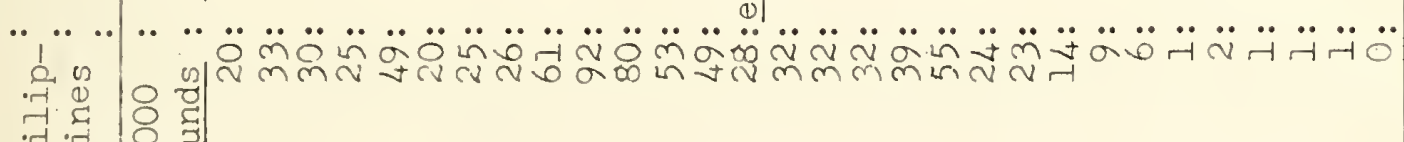

का त्र

n 1 o t)

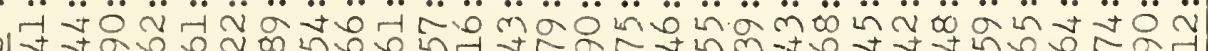

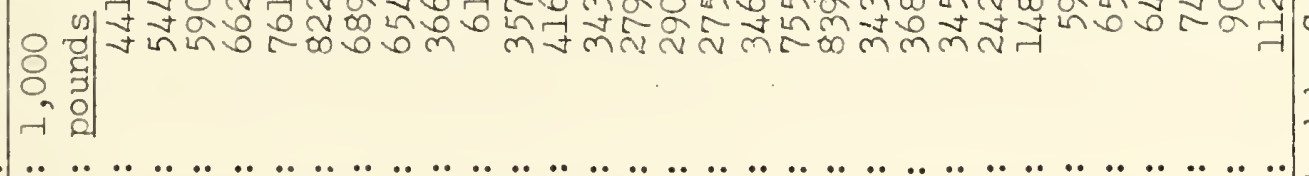
ह ह ב

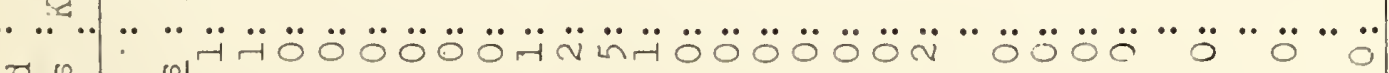

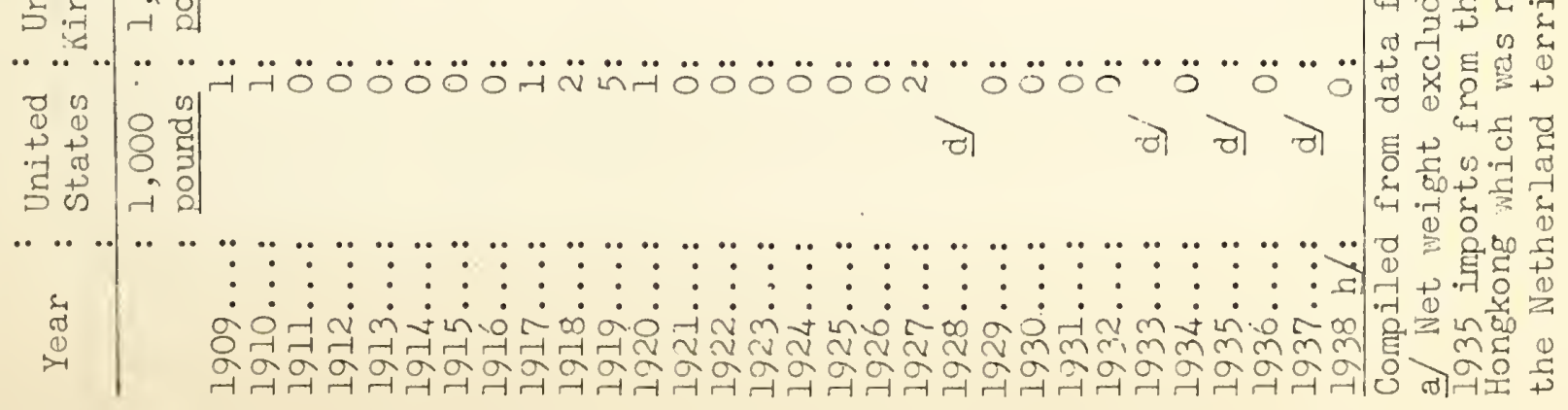




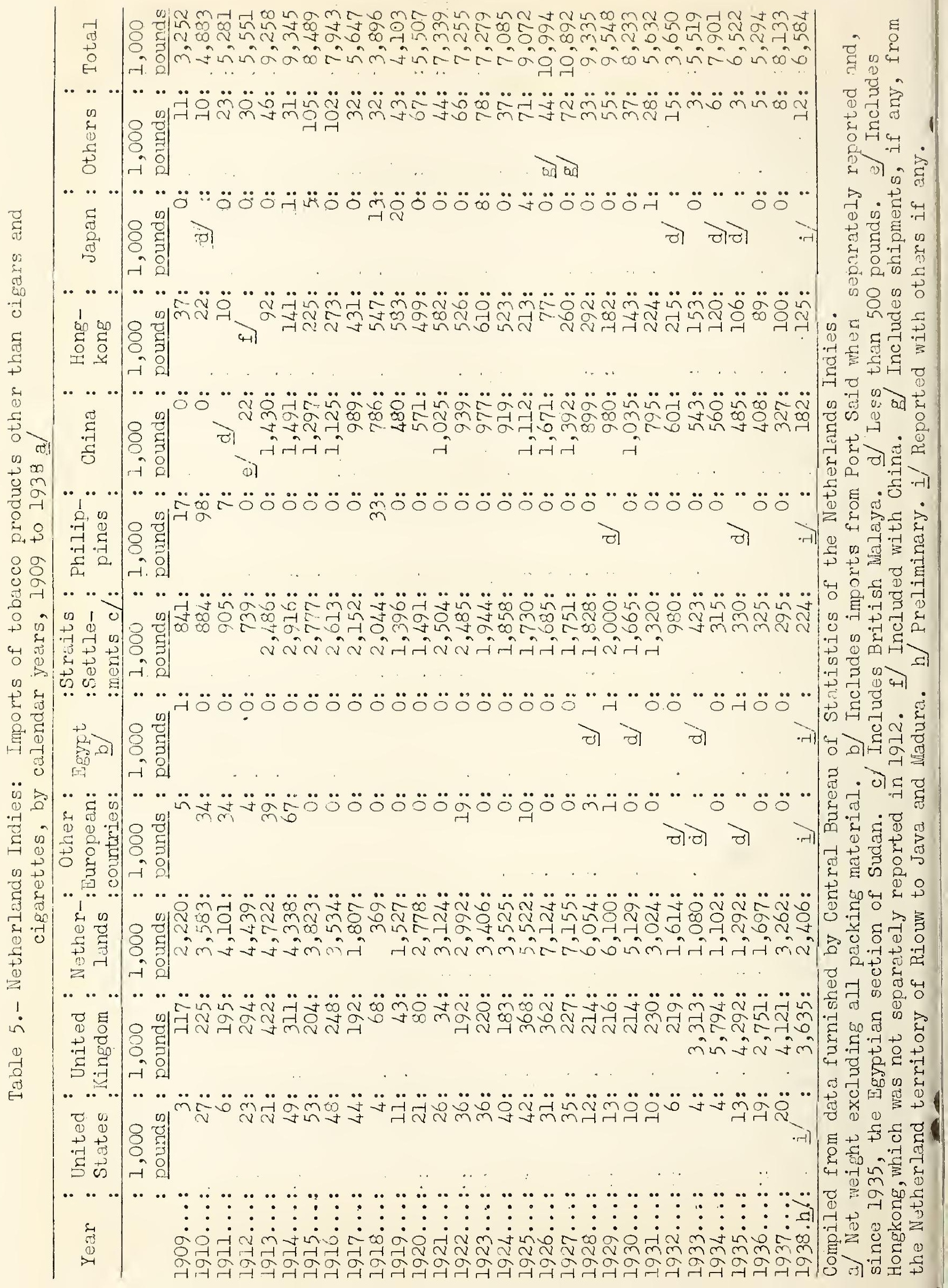


APPENDIX II

\section{Exports of Leaf I'obscco and Tobacco Products by Destinations 1909 to 1938}




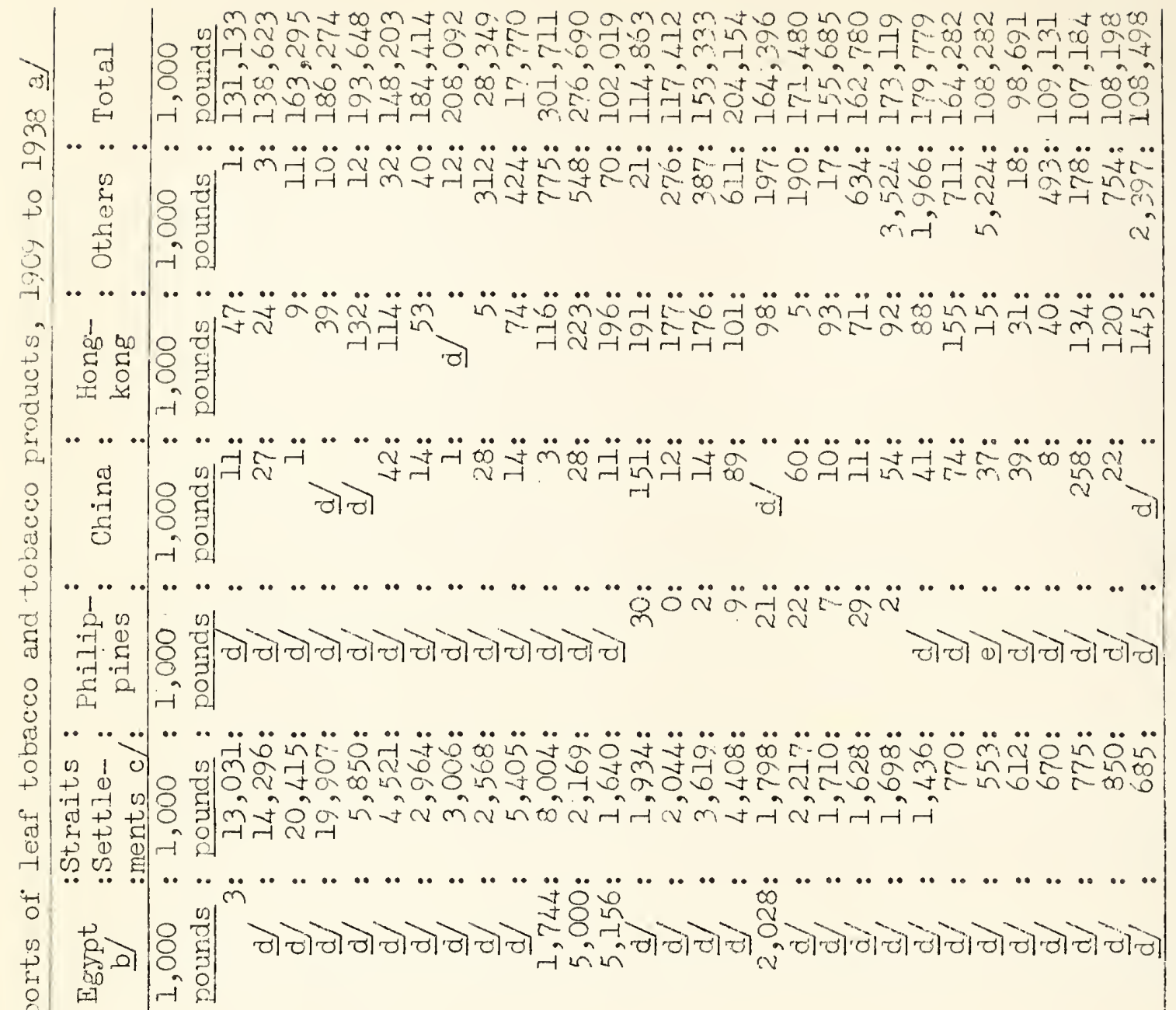

की (1) ए त त)

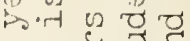
(1) 0 ज त्न म 0.410 क 0 ए

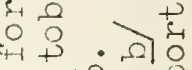
$0+\frac{0}{0} \cdot \frac{Q}{2}$ के ले

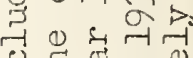
0 S 50

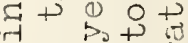
(1) 0 O 010 出

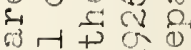
का क्ष

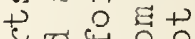
0 क्ष है ते +1 (1) 0 (1) $\rightarrow 0$ 1) $\circlearrowright 0 \frac{1}{5}$ (c) 0 (1) त्न + उ 4 ठ ए जण 0 त क 0

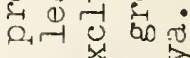
0 (1) ब ज ते Uु

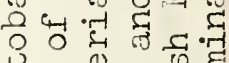

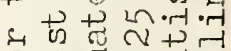

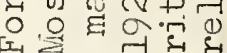
I ${ }_{0}$ ली मि ic $x+100$ 3 m 000

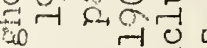

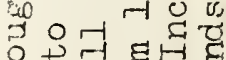
द त हम ह O है, .

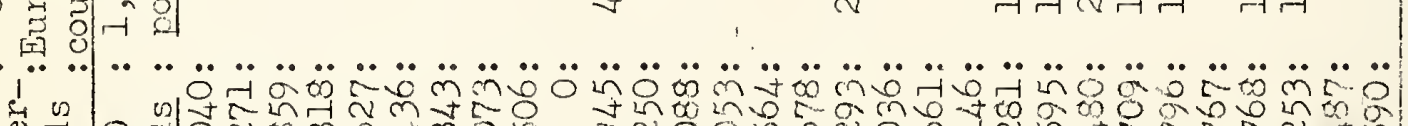
范 Q

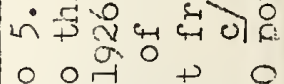

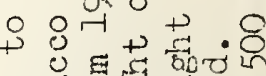

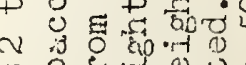

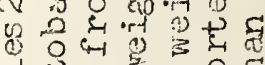

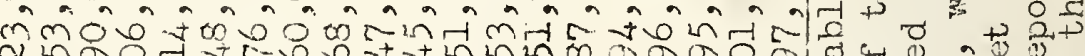
z

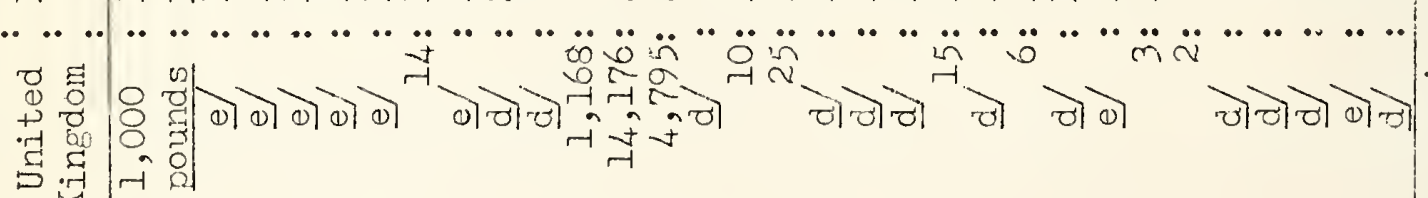

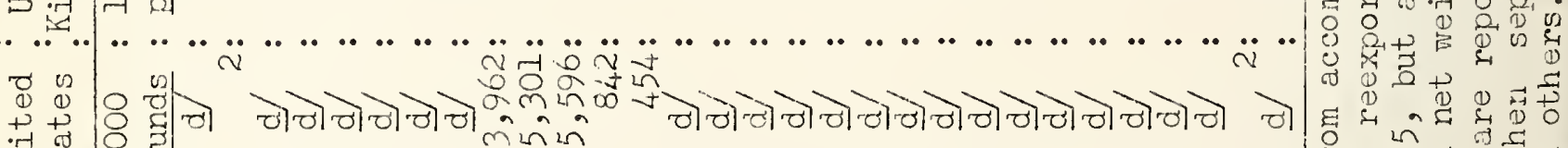

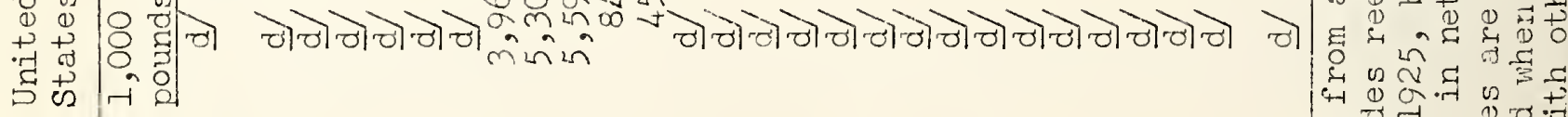




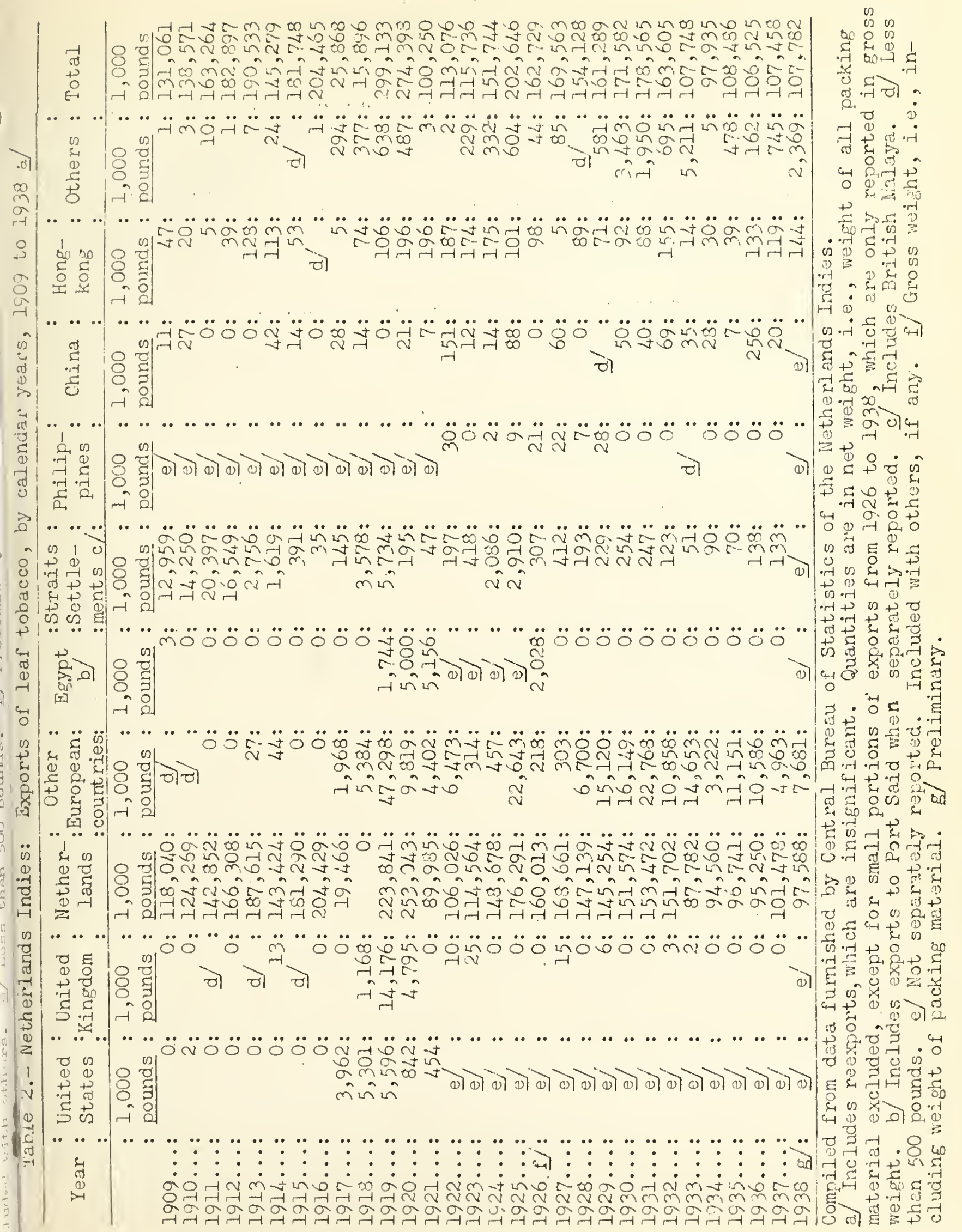




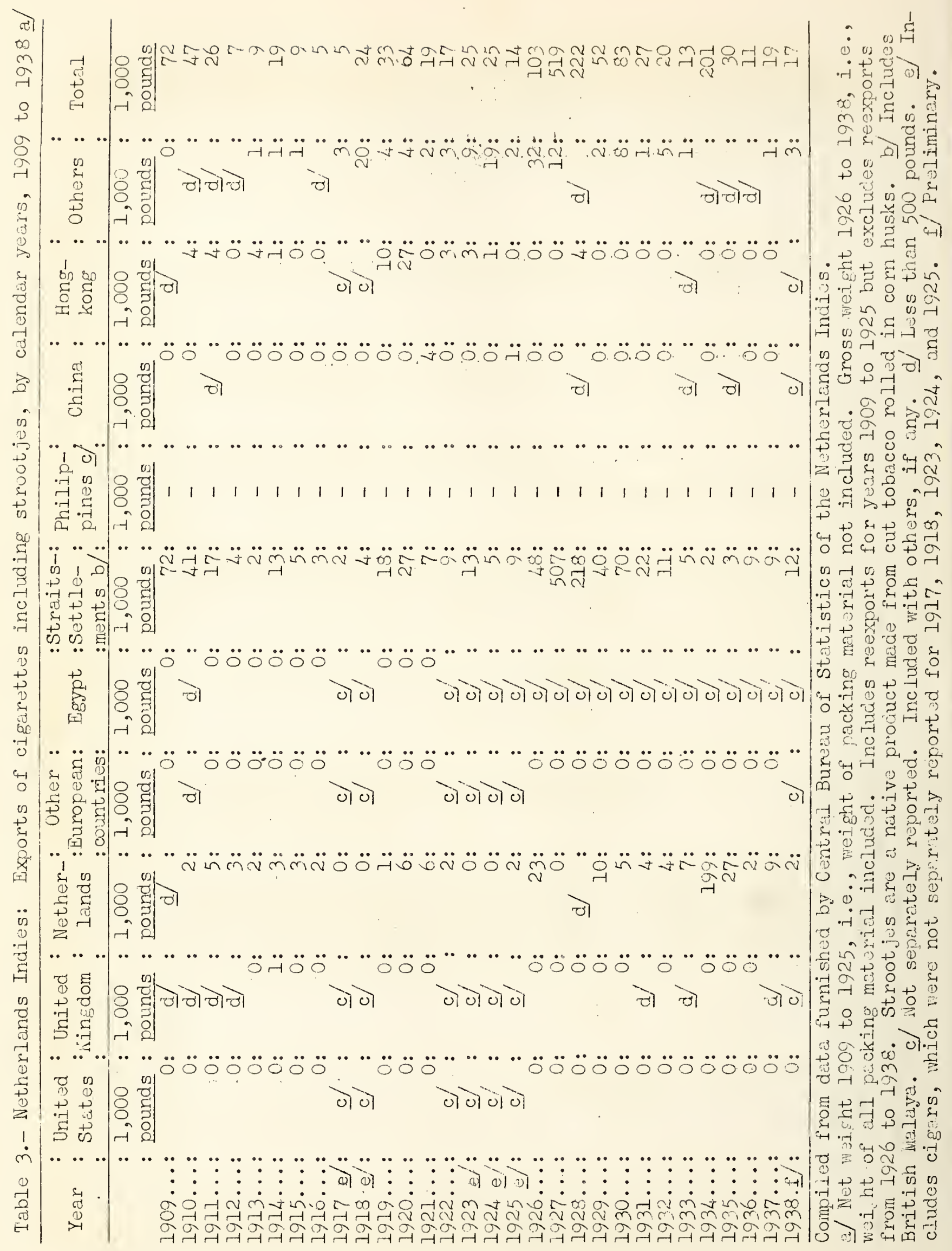




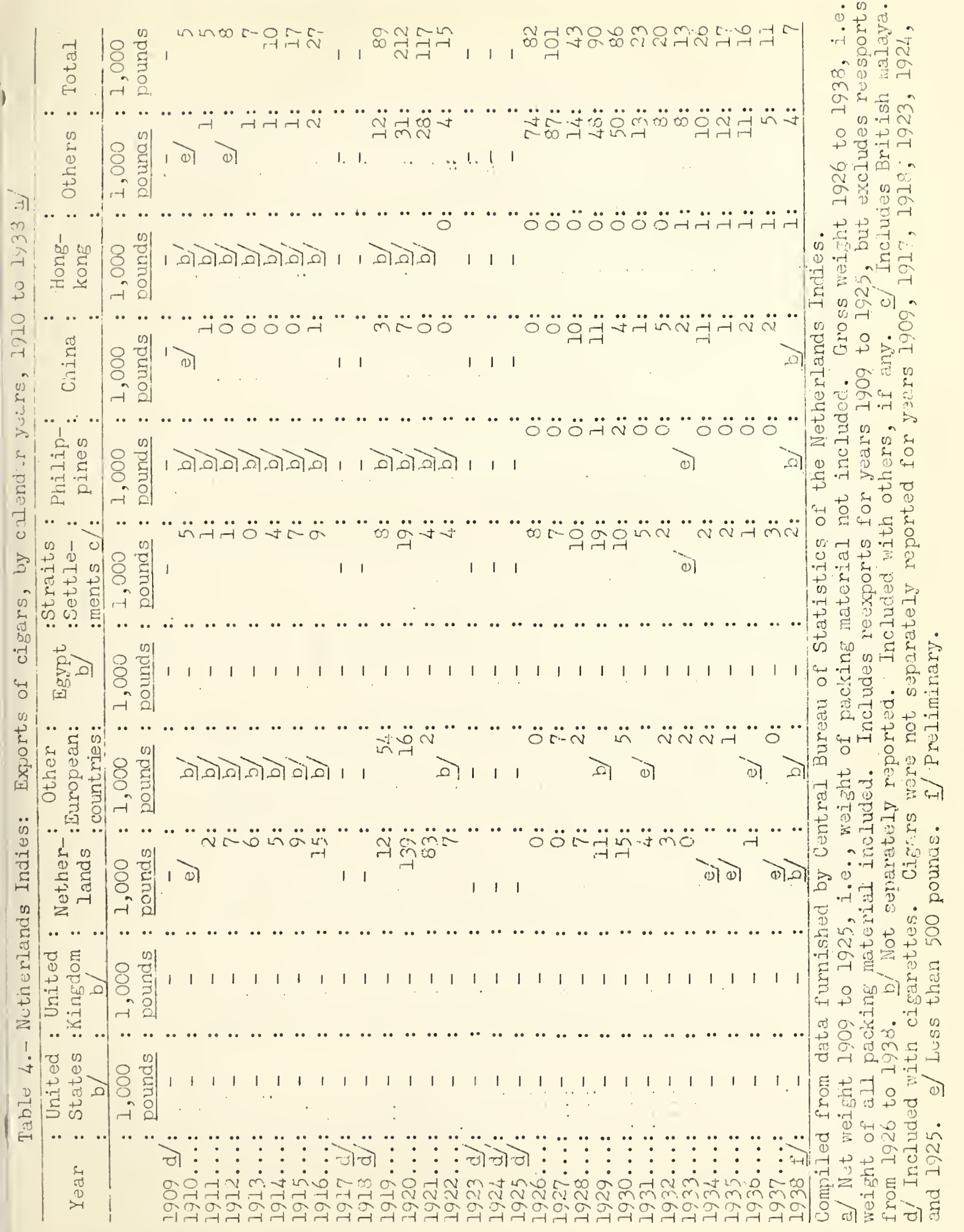




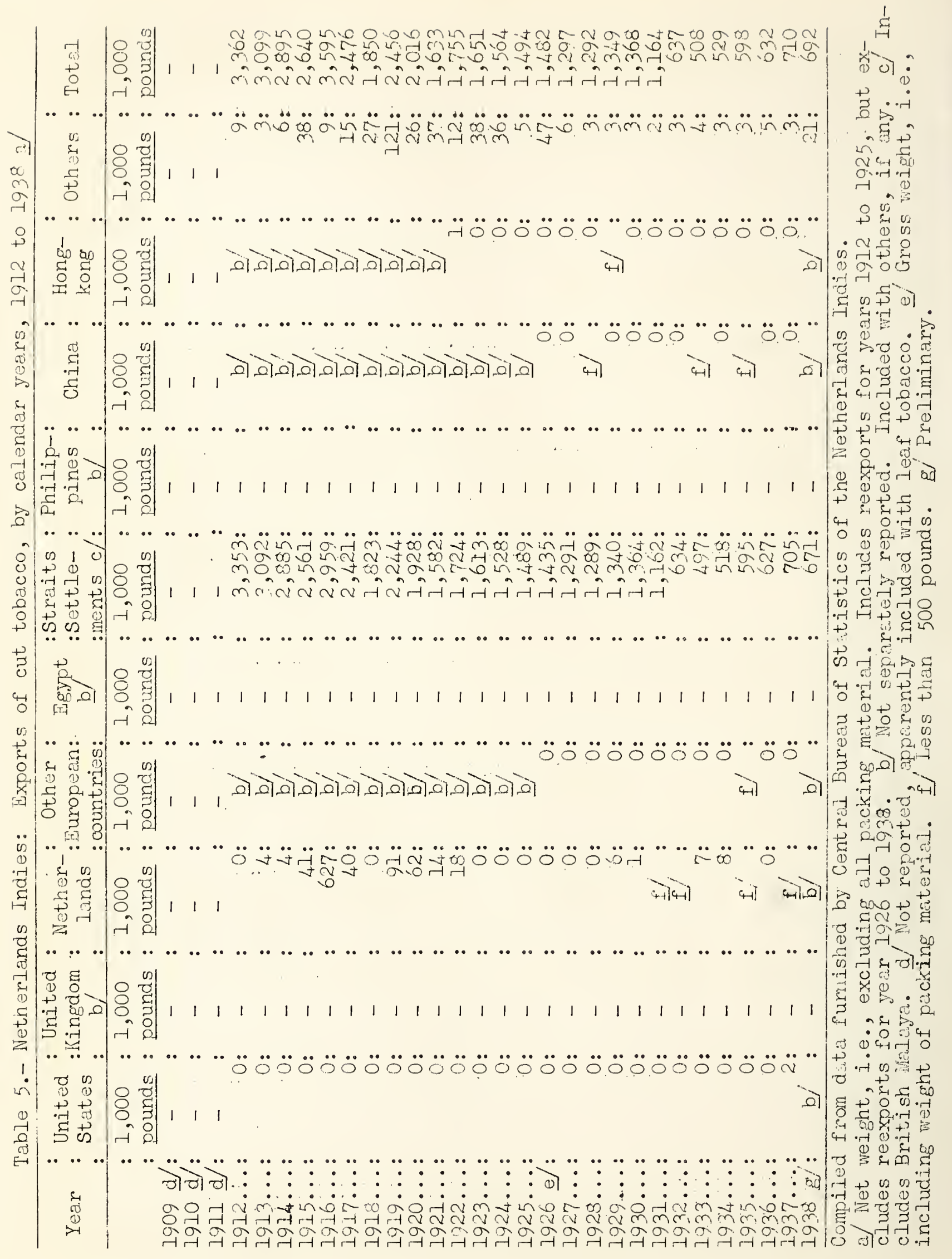




\section{SIAATSBLAD OF THE NETHERIANDS INDIES}

INDUSTRIES, LICENSES, PERITS, CIGARETTE FACTORIES

Promulgation of the "Industrial Regulation Ordinance, Cigarette Factories 1935"

IN THE NAME OF THE QUEEN:

The Governor General of the Netherlands Indies,

Greeting all who may see this or hear it read,

proclaims:

That He, considering it necessary, for the execution of the "Industrial Regulation Ordinance 1934" (Staatsblad IT. 595), to stipulate the following:

Having consulted the Council of the Netherlands Indies:

Has approved and decreed:-

\section{Article 1.}

In the application of this Government ordinance, the following definitions should apply:

a. Cigarette: Any tobacco product manufactured in the Hetherlands Indies of which the outside cover is paper and which is manufactured entirely by machinery.

b. Cigarette factory: A factory where cigarettes are produced.

c. Cigarette tax value: The retail price shown on the internal revenue stamp affixed to the cigarette container on the basis of the Tobacco Excise Ordinance 1932 (Staatsblad No. 517).

d. Consumption: The consumption of cigarettes in the Netherlands Indies during a certain period fixed by the Director and expressing the total cigarette tax value.

\section{Article 2.}

The "Industrial Regulation Ordinance 1934" shall apply to the cigarette factories in all of the Netherlands Indies. 


\section{$-68-$ \\ Lirticle 3 .}

(1) The forms of the application for obtaining licenses and permits shall be prescribed by the Director.

(2) The application must be accompanied, insofar as possible and to the satisfaction of the Director, by the necessary documentary evidence and signed statements to prove the validity of the application and the correctness of the particulars contained therein.

(3) The application, together with the documentary evidence and stitenents mentioned in the preceding paragraph, shall be suomitted, in Java and Madura, to the Assistant Resident; and, in the Outer Possessions, to the Head of the Local government in the territory where the cigarette factory is or may be established.

(4) The authorities mentioned in the preceding paragraph shall forward the application and the accompanying documents, provided that all the reauirements have been submitted vithin the period of time fixed by Article 5, paragraph 3, of the "Industrial Regulation Ordinance 1934," to the Director together with their recommendations thereon. Insofar as the Government territories of Java and Wadura are concemea, the said applications, documents and recomendations shall be forwarded to the Director after consultation with the respective Regents.

(5) The forwarding of the documents mentioned in the preceding paragraph shall be done in the Government districts of Java and liadura through the intermediary of the Resident; in the Vorstenlanden, through the Governor; and, in the Outer Possessions, through the district chiefs and Heads of the regional governments.

\section{Article 4.}

(1) Request for pernission to trensfer licenses and permits sheil be submitted in writing by the hoiders thereof to the Director through the intermediary of the authorities nentioned in Article 3, paragroph, above. Such requests must be accompcinied by tho necessiry docurnentary evidence in support of the requests.

(2) The forwarding of such reouest shall be done in the stme wray as is prescribed in trticle 3, paragrephs 4 and 5, in the cesse of licenses and permits.

\section{Article 5 .}

Licenses and permits, the forms of which shall be fixed by the Director, shall contain the following information.

a. The size of the industry, expressed in the percentage of the total production (equal to the total consumption). In connection therewith, the maxinum to be fixed by the Director, or the meximum tax value of the product, shall be taken into consideration. Production for exportation, however, shall be free. 
b. The working methods and the nature of the enterprise concerned.

c. The conditions under which the factory, if closed, was put out of operation.

\section{Article 6 .}

(1) The licenses, permits and approvals mentioned in Articles 3, 4, and 7 of the "Industrial Regulation Ordinance 1934 ," the adverse decisions on inquiries and requests, and decisions on the cancelation of licenses and permits shall be forwarded by the Director to the interested parties through the intermediary of the authorities mentioned above in Article 2, paragraphs 3 and 5.

(2) It shall be ascertained periodically, as far as possible, in a way to be prescribed by the Director, whether the particulars mentioned in the licenses and permits agree with the actual conditions in the cigarette factories.

\section{Article 7.}

(1) The closing of cigarette factories, on the basis of Article 10 of the "Industrial Regulation Ordinance 1934" shall be ordered by decree of the Director who shall give his reasons therefor. The said decree shall show the manner in which the factory shajl be closed.

(2) The authorities nentioned above in Article 3, paragraph 3, shall apply the decrees mentioned in the preceding paragraphs.

\section{Article 8.}

(1) The president and members of the committee of experts, provided for in Article 17 of the "Industrial Regulation Ordinarce 1934", shall be appointed and discharged by the Director; provided, however, that in any case the following shall have seats in the committee:

Ist. Ht least three experts in the cigarette industry.

2d. At least ore expert in tobacco growing.

3d. At least one expert in the tobacco tracie.

(2) The advice of the committee shall be obtained in writing by or on behalf of the Director with regurd to any application for a permit and in any other case where the Director may consider such advice necessary.

(3) The Director may fix a period of time within which the ruousted advice shall be submitted to him.

\section{Article 9.}

(1) In order to defray the expenses incurred in the application of these regulations, an annus $f$ ee of Florin 0.30 for each thousand guilders or part thereof of the cigarette tax value of the total production, on the basis of the license and permits, shall be paid in the case of exch license or permit issued. 
(2) Should a permit for the extension of a factory or for the introduction of a new method of working be grint d, the annual fee shall be fixed after due consideration of the provisions of the preceding paragraph.

(3) The dates and mothod of paying the annusl fec, due in accordance with the preceding paragraph shall be prescribed by the Director.

(4) The prompt payment of these fees is included in the conditions mentioned in Article 9 a of the "Industrial Regulation Ordinance 1934."

\section{Article 10.}

(1) This government ordinance may be referred to as the "Industrial Kegulation Cigarette Factories 1935."

(2) There regulations shall take effect on September 1, 1935.

In order that no one may plead ignorance of these regulations, they shall be pubiished in the Staatsbled of the Netherlands Indies.

Done at Batavia, Ausust 22, 1935.

Published on August 30, 1935

The Secretary General

P. J. GERKE
DE JONGE.

THE SECRETHRY GENERAI

$$
\text { P. J. GERKE. }
$$

(Decree of the Governor General

of Au ust 22, 1935, No. 34).

Translated from the original, Uffice of American Trade Comissioner, Batavia, Java. 

